\title{
Late Pleistocene sediments, landforms and events in Scotland: a review of the terrestrial stratigraphic record
}

Jon W. Merritt ${ }^{1}$, Adrian M. Hall ${ }^{2}$, John E. Gordon ${ }^{3}$ and E. Rodger Connell ${ }^{4}$

${ }^{1}$ British Geological Survey, The Lyell Centre, Research Avenue South, Edinburgh EH14 4AP, UK.Email: jwm@bgs.ac.uk

2 Department of Physical Geography, Stockholm University, 10691 Stockholm, Sweden.

${ }^{3}$ School of Geography and Sustainable Development, University of St Andrews, St Andrews KY16 9AL, UK.

${ }^{4}$ Geology, School of Environmental Sciences, University of Hull, Hull HU6 7RX, UK.

Running head abbreviation: Late Pleistocene Scotland 
ABSTRACT: Lithostratigraphical studies coupled with the development of new dating methods has led to significant progress in understanding the Late Pleistocene terrestrial record in Scotland. Systematic analysis and re-evaluation of key localities have provided new insights into the complexity of the event stratigraphy in some regions and the timing of Late Pleistocene environmental changes, but few additional critical sites have been described in the past 25 years. The terrestrial stratigraphic record remains important for understanding the timing, sequence and patterns of glaciation and deglaciation during the last glacial/interglacial cycle. Former interpretations of ice-free areas in peripheral areas during the Last Glacial Maximum (LGM) are inconsistent with current stratigraphic and dating evidence. Significant challenges remain to determine events and patterns of glaciation during the Early and Middle Devensian, particularly in the context of offshore evidence and ice sheet modelling that indicate significant build-up of ice throughout much of the period. The terrestrial evidence broadly supports recent reconstructions of a highly dynamic and climate-sensitive British-Irish Ice Sheet (BIIS), which apparently reached its greatest thickness in Scotland between 30 and 27 ka, before the global LGM. A thick (relative to topography) integrated ice sheet reaching the shelf edge with a simple ice-divide structure was replaced after the LGM by a much thinner one comprising multiple dispersion centres and a more complex flow structure.

KEY WORDS: Chronostratigraphy, ice sheet, last glacial-interglacial cycle, lithostratigraphy

(C) 2018 Natural Environment Research Council (NERC) as represented by the British Geological Survey (BGS). Published by ...... All rights reserved. 
The Pleistocene covers the greater part of the Quaternary period, from $2.58 \mathrm{Ma}$ to $11.7 \mathrm{ka}$ (Gibbard \& Lewin 2016). Its defining characteristic is a series of climatic cycles resulting in repeated glaciations that had a profound, but variable effect in shaping the modern landscape of Scotland, adding cumulatively to the effects of longer-term landscape evolution (Hall et al. 2018). During the glacial stages, mountain glaciers developed in the uplands and ice sheets extended periodically out across the continental shelf and into the North Sea basin (Stewart et al. 2019 and references therein). During the intervening interglacial stages, temperate climatic conditions prevailed leading to more equable environments. The record of these climatic and environmental changes is documented in the terrestrial sedimentary record typically by a variety of glacial and periglacial deposits, organic deposits and palaeosols. However, because much of Scotland lay close to ice accumulation centres, successive glaciations have generally removed traces of earlier events. Hence, there is dominance of the last glacial cycle and, especially, its final deglaciation, in the terrestrial stratigraphic record. Exceptionally, in some areas, the former presence of cold-based ice appears to have allowed the local preservation of relatively long sedimentary sequences, as for example, in NE Scotland (Hall et al. 2018). The preservation of earlier events is fragmentary, both in space and time. Nevertheless, the terrestrial evidence represents a significant and accessible record.

The glacial landform and sedimentary archives, including the BRITICE database of landforms and features related to the last British-Irish Ice Sheet (BIIS) (Clark et al. 2004, 2018; Evans et al. 2005), provide good opportunities to elucidate the history of Quaternary glaciation in Britain, and particularly for understanding the dynamics of the last BIIS, its response to the changing climate and the links between ocean circulation and climate change. The BIIS was largely marine-based (Stewart et al. 2019) and because of the extreme maritime location of the British Isles, it is considered to have been highly sensitive to climate changes (Hibbert et al. 2010; Thierens et al. 2012).

The aim of this paper is to review the Late Pleistocene terrestrial stratigraphy of Scotland over the time period 130-14.7 ka and spanning the last glacial-interglacial cycle (Lisiecki \& Raymo 2005). We first summarise recent advances in understanding the lithostratigraphic and chronostratigraphic framework for Scotland over the last 25 years since the publication of the Quaternary of Scotland Geological Conservation Review (GCR) volume (Gordon \& Sutherland 1993a), then review the evidence from a number of critical regions. Finally, we consider outstanding questions, new directions and challenges. The focus of the paper on Late Pleistocene terrestrial stratigraphy complements the accompanying review of the terrestrial record of Early and Middle Pleistocene environments, landforms and sediments in Scotland (Hall et al. 2018), offshore stratigraphy (Stewart et al. 2019) and the geomorphological evidence for the last Scottish Ice Sheet and its deglaciation (Ballantyne \& Small 2018). Lateglacial landforms and landscape evolution, including evidence relating to the glaciation of Scotland during the Loch Lomond Stadial (Younger Dryas), are reviewed by Ballantyne (2018), whereas evidence for sea level change is reviewed by Smith et al. (2018).

Radiocarbon ages are given as ${ }^{114} \mathrm{C}$ ka BP" (thousands of years before present). Calibrated ages are quoted as "cal ${ }^{14} \mathrm{C}$ ka BP". 


\section{The Quaternary stratigraphic framework}

Onshore Quaternary deposits are classified and correlated principally using lithostratigraphy, chronostratigraphy and geochronometry. The first is based on the observable physical characteristics of the sediments and their relative stratigraphic positions; the second requires establishing the time relationships between different sedimentary units in relative terms and through numerical dating methods (geochronometry). Climatostratigraphy is also used where climatic changes are represented in the deposits. In some cases, deposits may also be classified according to their biostratigraphy, or microfossil content; while in others, geomorphological subdivision may be possible using morphostratigraphy, which incorporates the landform record. Periglacial and organic sediments are rarely preserved within the Pleistocene sequence, but are particularly important stratigraphical markers providing evidence of ice-free episodes. A key element in stratigraphical analysis is the designation of type sections and type localities establishing named stratigraphic units, which provide a common standard of reference for their identification (Bowen 1999; McMillan \& Merritt 2012). Details of all units referred to below are fully documented by McMillan et al. (2011a).

\subsection{Climatostratigraphy and chronostratigraphy}

Quaternary stratigraphy was revolutionised during the latter part of the 20th century by the recovery of deep-sea cores, which provided continuous sedimentary records for the whole of the Quaternary. A series of Marine Isotope Stages (MIS), based on the oxygen isotope composition of the microfaunas contained in the cores (Bowen 1978; Lisiecki \& Raymo 2005; Thierens et al. 2012; Railsback et al. 2015), now provides a reference climatostratigraphic framework for the correlation of Pleistocene terrestrial sediments and events in Scotland (Hall et al. 2018, fig. 1). In the conventional British chronostratigraphic scheme, the Late Pleistocene spans the Ipswichian ( 130-116 ka) and Devensian ( 11611.7ka) stages (Fig. 1), corresponding to MIS 5e and MIS 5d-2, respectively (Lisiecki \& Raymo 2005). The Devensian is subdivided into Early Devensian ( 109-57 ka) (MIS 5d-4), Middle Devensian ( 57-31 ka) ( MIS 3) and Late Devensian ( 31-11.7 ka) ( MIS 2). The Late Devensian includes the Dimlington Stadial ( 31-14.7 ka) (Rose 1989), the Lateglacial or Windermere Interstadial (14.7-12.9 ka) and the Loch Lomond Stadial (12.9-11.7 ka). The Lateglacial period, or Last Glacial Transition (LGT), is generally acknowledged to have occurred between c. $21 \mathrm{ka}$ and 11.7 ka (Lowe \& Walker 2015).

There are different interpretations of the timing of the Last Glacial Maximum (LGM) globally, regionally and locally, according to different indicators - the timing of global sea level minimum, the oxygen isotope signal in marine records and terrestrial records (Clark et al. 2009; Hughes et al. 2013; Lambeck et al. 2014; Hughes \& Gibbard 2015). Different sectors of the last BIIS apparently reached their maximum extent asynchronously (Ballantyne \& Small 2018). The estimate of 30-27 ka for ice reaching the Atlantic Shelf (Ballantyne \& Small 2018) is earlier than the timing of some estimates of 26-21 ka (Clark et al. 2009), but is in line with the time-slice reconstruction of 27-26 ka for this sector from Hughes et al. (2016) (See also section 3.2). In line with Ballantyne \& Small (2018) we use the abbreviation LGM to denote the last global glacial maximum of 26.5 to 19 ka (Clark et al. 
2009) and LLGM (local last glacial maximum) to refer to the maximum extent of different sectors of the last BIIS (Fig. 1), some of which apparently reached their outermost limits millennia before others.

In a second major development, analyses of the stable-oxygen isotope signals in cores drilled through the Greenland Ice Sheet have enabled the interpretation of continuous records of climate change defining a series of stadials and interstadials extending back to the last (Ipswichian) interglacial (Lowe \& Walker 2015). Because of the high stratigraphic and temporal resolution, these records form the basis for an event stratigraphy and a framework for the whole of the last glacial-interglacial cycle for the North Atlantic region (Fig. 2) (Rasmussen et al. 2014) (see section 2 below).

The development and application of new dating techniques applied to terrestrial materials has also significantly improved the temporal resolution of onshore Quaternary stratigraphy and the identification of events (Lowe \& Walker 2015). In particular, surface exposure dating using terrestrial cosmogenic nuclides (cosmogenic dating) has greatly enhanced the understanding and timing of the pattern of growth and decay of the last ice sheet (e.g., Ballantyne 2010; Ballantyne \& Small 2018). Nevertheless, it is clear that only a fragmentary record of the Quaternary is preserved in terrestrial deposits.

\subsection{Lithostratigraphy}

The traditional approach of establishing contact relationships, sedimentology and lithostratigraphical correlations of named units has helped to decipher the sequence of events and glacial interactions that have occurred in Scotland. The formal 'top-down' lithostratigraphical framework of McMillan et al. (2011a) is followed here. In this scheme, the Great Britain Superficial Deposits Supergroup includes seven named groups, including (in Scotland) the British Coastal Deposits Group embracing raised marine and coastal deposits, the Britannia Catchments Group, comprising predominantly fluvial deposits, and a Residual Deposits Group including mainly remanié deposits and other units that have undergone prolonged dissolution (Table 1). Two groups are assigned for glacigenic deposits, namely the Caledonia Glacigenic Group, of MIS 5e-2 age, and the Albion Glacigenic Group, representing older glaciations. Deposits of these groups in Scotland are included in a series of subgroups that have been divided geographically, some by natural boundaries, such as the Great Glen, but mostly on the basis of overall lithology and provenance of the constituent formations (Fig. 3A). The concept of subdivision is not new; for example, in NE Scotland three 'series' of glacigenic deposits have been recognised traditionally relating to distinct bodies of ice that existed in the region during past glaciations (Merritt et al. 2003, 2017a). The glacigenic sequences include some non-glacial, terrestrial sediments, periglacial deposits and soils that provide important biostratigraphical and geochronometric evidence and stratigraphical markers. These units are included in the Britannia Catchments Group.

A first step towards a systematic geographical delineation of surficial till units in Britain was undertaken in 2009 (Entwisle \& Wildman 2010), utilizing the British Geological Survey (BGS) Superficial and Bedrock Geology themes draped on hill-shaded digital elevation models (http://www.bgs.ac.uk/data/maps/home.html) (Fig. 3B). Archive BGS mapping, digital air photos and other relevant data were used in that exercise, including the BRITICE 
database (Clark et al. 2004; Evans et al. 2005). Similar protocols were followed as for the delineation of glacigenic subgroups, using literature review and prior knowledge of general ice-flow trajectories, glacial history and simplified bedrock geology. As the matrices of tills are known to bear a strong relationship with underlying bedrock (Benn \& Evans 2010), many boundaries are positioned a short distance 'down ice' of significant changes in bedrock geology. The use of descriptive qualifiers (such as 'till') and other issues of protocol are discussed by McMillan \& Merritt (2012).

\section{The Late Pleistocene record}

The climate records inferred from offshore sediment cores and Greenland Ice Sheet cores highlight the variability of Late Pleistocene climate (Fig. 2). For example, they reveal 26 clearly-defined stadials and interstadials, with numerous sub-events (Rasmussen et al. 2014). However, events in Scotland, and particularly the timing and pattern of glacier and ice sheet development, remain uncertain because of the absence of unambiguous local stratigraphic evidence and dating. Nevertheless, a broad picture may be inferred from the Greenland event stratigraphy (Lowe et al. 2008b; Rasmussen et al. 2014), offshore evidence from the Atlantic Shelf adjacent to Scotland (e.g., Hibbert et al. 2010), the speleothem record from caves in Northern England (Latham \& Ford 2013) and comparison with the fluctuations of the Fennoscandian Ice Sheet (FIS) (Hughes et al. 2016; Patton et al. 2016, 2017), particularly regarding evidence of its presence in the North Sea basin (Phillips et al. 2017; Stewart et al. 2019).

Clapperton (1997) used the Greenland Ice Core Project (GRIP) Summit ice core $\delta^{18} \mathrm{O}$ record to infer time intervals during the Devensian when climate conditions in Scotland could have supported different types of ice mass, including ice sheets, mountain ice caps and corrie glaciers (Fig. 2). Although such extrapolation is over-simplified, it nevertheless suggests that glaciers in one form or another are likely to have existed in Scotland for extended parts of the Devensian.

Core MD04-2822 from the Rockall Trough, beneath the Atlantic Ocean $300 \mathrm{~km} \mathrm{~W}$ of Scotland, provides lithological evidence for the build-up and expansion of the BIIS across the Hebridean Shelf during the Early Devensian (MIS 4), fed by ice sources in Scotland and Northern Ireland. Pulses of ice-rafted debris (IRD) occurred at 70.2 and 61.7 ka (Hibbert et al. 2010). The same core, and core MD95-2006 from the Barra-Donegal Fan, some $200 \mathrm{~km}$ W of the Scottish mainland (Hall et al. 2018, fig. 2), demonstrate limited delivery of IRD diagnostic of British Palaeogene Igneous Province sources in Scotland and Northern Ireland to these sites during the early part of MIS 3. However, pulses followed at 41 ka and $38.5 \mathrm{ka}$ and a steep increase occurred at 27.4 ka (Knutz et al. 2001; Peters et al. 2008; Hibbert et al. 2010). This pattern of IRD delivery is consistent with the periods of cooling in the North Atlantic region revealed in the Greenland ice cores and indicates BIIS growth during the Early Devensian of sufficient size and extent to deliver IRD to the coring sites, followed by dynamic and fluctuating glacial responses to climate change. It supports previous indications of Early Devensian ice sheet glaciation (Sutherland 1981; Sissons 1983; Bowen \& Sykes 1988; Bowen et al. 2002). 
Comparison with SW Norway also lends support to dynamic glacial responses following MIS 5e. For example, extensive ice-free conditions are indicated during the warm phases of MIS 5c and 5a (Helle et al. 1981; Hughes et al. 2016), whereas during the MIS 5b and 5d cold intervals, glaciers extended to the present coast at limits similar to, or just outside those of glaciers in the Younger Dryas (Mangerud 2004). During MIS 4 and early MIS 3, all of southern Norway was ice covered, with the ice sheet extending into Denmark at 65-60 ka and 55-50 ka (Larsen et al. 2009) and onto the bed of the northern North Sea (Carr et al. 2006). Later in MIS 3, the timing of glacial-interstadial phases is constrained by sediments in coastal caves in western Norway (Larsen \& Mangerud 1989; Valen et al. 1995, 1996). Ice advanced beyond the present coastline at $\sim 41 \mathrm{ka}$, with withdrawal by $38 \mathrm{ka}$. During Greenland Interstadials GI 8-GI 7, at 38.2-34.5 ka, coastal areas were free of glacier ice during the Ålesund Interstadial, with sufficient vegetation cover for reindeer to graze (Mangerud et al. 2011). Expansion of the last Fennoscandian ice sheet may have occurred later than in Scotland, with ice first reaching limits in northern Denmark after $29 \mathrm{ka}$. Radiocarbon dates for marine shells indicate that the Witch Ground Basin beneath the central North Sea remained ice free until after 34.7-32.4 ka (Sejrup et al. 2015) or 36.1-33.7 ka (Graham et al. 2010). Ice withdrew from northern Denmark at 27-23 ka before advance to maximum limits at 23-21 ka (Larsen et al. 2009)

Most of the glacigenic deposits in Scotland were laid down during the Late Devensian. The last Scottish Ice Sheet, which dominated the BIIS, appears to have expanded sometime after 35-32 ka based on radiocarbon dates from sediments underlying glacial deposits in the Central Lowlands (Section 5.4). It reached its maximum extent on the Atlantic Shelf at $\sim 30-27 \mathrm{ka}$, although this is now thought to have been neither synchronous across different parts of the ice sheet (Ballantyne \& Small 2018), nor in tandem with the FIS (Section 3.2). Numerical modelling indicates that the ice sheet was highly dynamic with rapid changes in extent (Boulton \& Hagdorn 2006; Hubbard et al. 2009; Patton et al. 2016, 2017). The terrestrial stratigraphy of Scotland therefore needs to be viewed in the context of a highly dynamic and climate-sensitive ice sheet that may have existed throughout much of the Devensian (Ballantyne \& Small 2018).

There have been significant advances in understanding of the lithostratigraphic and chronostratigraphic framework for Scotland since the publication of the Quaternary of Scotland (Gordon \& Sutherland 1993a). These are reviewed below for a number of critical regions that are grouped broadly into three categories with reference to former ice accumulation areas:

A. Peripheral areas: Shetland, Orkney, Caithness and the Outer Hebrides (Western Isles). These are significant because they include deposits that have been preserved locally beneath cold-based ice and provide key information on the timing of ice sheet advance and retreat.

B. Core areas: the North-west Highlands and Central Highlands. These are significant because they were the main centres of ice accumulation beneath which older deposits have been preserved locally due to relatively little subglacial erosion. 
C. Lowland depocentres: Inverness and the Great Glen, NE Scotland, Southern Argyll and Arran, the West Central Lowlands and the Solway Lowlands. These are significant for thick sequences of multiple tills and intercalated sediments.

\section{Peripheral areas}

Scottish ice reached its maximum limits during the Middle and Late Devensian marked by a series of moraine ridges close to the NW Atlantic shelf edge (Bradwell et al. 2008a; Clark et al. 2012). At this time the BIIS is believed to have been confluent with the FIS in the North Sea (Graham et al. 2011; Ballantyne \& Small 2018). Earlier claims that ice-free areas existed at the LGM at low elevations in peripheral parts of Scotland (Sutherland 1984), particularly in Lewis (Sutherland \& Walker 1984), Caithness and Orkney (Bowen \& Sykes 1988) and in Buchan (Synge 1956, 1963), have been shown to be inconsistent with new stratigraphic and dating evidence for LGM ice cover in these areas (Hall \& Whittington 1989; Hall 1995; Whittington et al. 1998; Ballantyne \& Hall 2008; Hall \& Riding 2016). Nonetheless, the stratigraphic record in these peripheral areas remains of high importance for understanding the timing, sequence and pattern of the last ice sheet glaciation and associated environmental changes.

\subsection{Shetland}

Shetland, Orkney and Caithness together form a topographic divide between the NE Atlantic and the North Sea (Hall et al. 2018, fig. 2). On Shetland, there has been debate since the $19^{\text {th }}$ century as to whether the islands supported a local ice cap (Milne-Home 1881; Flinn 1978) or if they were overwhelmed by the FIS during the last glaciation (Peach \& Horne 1879; Sutherland \& Gordon 1993b). That debate continues (Ross 1996; Golledge et al. 2008; Flinn 2009; Carr \& Hiemstra 2013). The identification of only one Scandinavian erratic on the islands (Finlay 1926), the absence of Permian to Neogene palynomorphs in tills derived from the bed of the North Sea and evidence of radial ice flow patterns from erratics, glacial bedforms and striae (Fig. 4) provides little support for former flow of ice across Shetland (Hall 2013). There is no evidence from erratics that Scottish ice reached Shetland (Hall 2013), except Fair Isle, midway between Shetland and Orkney (Hall \& Fraser 2014). Consequently, the balance of evidence strongly supports the existence of an independent Shetland ice cap (SIC) during the Late Devensian (Hall 2013).

The oldest Quaternary sediment recognised on Shetland is from Fugla Ness (Fig. 4) (Table 2), on the island of North Roe, where coastal erosion has exposed a shallow basin developed in bedrock within glacially-scoured 'cnoc-and-lochain' terrain (Chapelhowe 1965) (Fig. 5). Resting above 'rock-face breccia' (gelifractate?) on the striated floor of the depression is the Fugla Ness Lower Till, with a fabric indicating ice flow to the W or NW (Hall et al. 1993b, 2002). The overlying, compacted organic deposits of the Fugla Ness Peat Bed thicken towards the centre of the basin, comprising a thick lower unit containing some wood fragments and thinner layers above with more wood, small pine stumps and pine cones (Birks 1993a). The presence of thermophilous pollen and macrofossils indicates that the peat formed during an interglacial (Birks \& Ransom 1969). The pollen record indicates that Pinus and possibly Ilex grew locally in sheltered areas in a mild, oceanic climate, possibly with wind speeds lower than today (Hall et al. 2002). The maritime heath flora has been 
compared to that of the Gortian Interglacial in Ireland (Birks \& Ransom 1969), but it is also consistent with existing environmental reconstructions for the Ipswichian/Eemian interglacial in maritime NW Europe (Hall et al. 2002). A uranium-series age of $110+40 /-35$ ka supports the case that the Fugla Ness Peat was formed during the last interglacial (MIS 5e) (Hall et al. 2002). The later change in vegetation indicated by the pollen record suggests a drop in annual temperature and an increased frequency of frosts (Birks \& Ransom 1969). The high representation of grasses in the pollen reworked into the overlying Fugla Ness Breccia may reflect a climatic deterioration to periglacial conditions, which resulted in granular and blocky disintegration of the local bedrock accompanied by wash and solifluction of the debris into the basin (Hall et al. 2002). The apparent continuity of deposition has been used to suggest that the breccia formed during MIS $5 d$, when periglacial conditions prevailed throughout NW Europe (Aalbersberg \& Litt 1998).

Organic sediments and peat are also found beneath till and periglacial deposits at Sel Ayre, on the Sandness peninsula of Mainland Shetland (Birks \& Peglar 1979; Birks 1993b; Hall et al. 1993a) (Fig. 4, 6). The Sel Ayre Lower Breccia records periglacial conditions. These coarse sediments retain no record of any vegetation cover, but are tentatively assigned to MIS 5d (Hall et al. 2002). The overlying Sel Ayre Organic Sands and Gravels are attributed to MIS $5 c$ on the basis of pollen stratigraphy and luminescence ages of ca. 105-98 ka from intercalated sands (Duller et al. 1995). The pollen record indicates that an earlier grassland environment was followed by ericaceous heath with associated changes in soil type, with a brown earth of the grassland being replaced by the bleached sand of a more podzolic soil (Birks 1993b). This was followed by open, grass-dominated vegetation with a variety of herbs characteristic of skeletal mineral soils. The Sel Ayre sequence appears to record major environmental changes through the MIS 5c interstadial on Shetland (Hall et al. 2002). The overlying Sel Ayre Upper Breccia is devoid of organic material, but apparent continuity of deposition suggests that it may date from the succeeding cold interval, MIS 5b, when periglacial conditions returned to the lowlands of NW Europe (Aalbersberg \& Litt 1998).

Till fabric data from the Fugla Ness Upper Till (Fig. 5) and Sel Ayre Till (Fig. 6) are consistent with the patterns of ice flow during the local ice cap phase of glaciation (Hall et al. 2002). This phase is usually attributed to the Late Devensian, although firm dating evidence is lacking (Gordon et al. 1993; Ross et al. 1993; Ross 1996). Despite suggestions on geomorphological criteria that ice-free areas existed during the LGM on northern Unst and Yell (Flinn 1983; Long \& Skinner 1985), and also Ross (1996), offshore data indicate that the SIC extended well beyond the current landmass to the $E$ and $N$, and close to the edge of the continental shelf W of Shetland (Johnson et al. 1993; Stoker et al. 1993; Ross 1996). Sets of moraines on the West Shetland Shelf have been interpreted to represent multiple phases of expansion of the SIC during the Middle and Late Devensian (Davison 2004). Stacked till sequences have not been widely recognised on Shetland (Ross 1996), where till is generally thinly developed (Hall 2013). Only single till units are recognised above the MIS 5 organic sediments at Fugla Ness and Sel Ayre (Hall et al. 2002), these units having been re-assigned to the Burrier Wick Till Formation (McMillan et al. 2011a) (Fig. 3B). However, marked differences in erratic content and lithology present within the till units on, for example, North Roe (Chapelhowe 1965) and on Unst (Golledge et al. 2008) (Fig. 4), suggest that a more complex glacial stratigraphy awaits elucidation. 
Flow of ice from SW Norway across Shetland is a recurrent feature of both classic $19^{\text {th }}$ century (Croll 1870; Peach \& Horne 1879, 1880) and modern ice sheet reconstructions (Bradwell et al. 2008a; Graham et al. 2010; Sejrup et al. 2016). Yet firm evidence for the former presence of the FIS (or BIIS) on Shetland is absent. In western Shetland, flow sets interpreted from Digital Elevation Models (DEMs) (Golledge et al. 2008) generally conform to patterns of westward ice flow recognised from the dispersal of erratics, striae and roches moutonnées (Mykura \& Phemister 1976; Flinn 1978; Hall 2013). Conflicting evidence has been reported from eastern Shetland, however, for the interpretation of mega-scale glacial lineations (MSGLs) (Golledge et al. 2008), and kinematics derived from glacitectonic structures (Carr \& Hiemstra 2013) suggests westward ice flow, whereas erratic dispersal, striae and roches moutonnées indicate eastward ice flow (Flinn 2009; Hall 2013) (Fig. 4A ).

The last glaciation of Shetland likely involved the development of an extensive ice cap that interacted with the Norwegian Channel Ice Stream (NCIS) between Shetland and Norway, and with ice flowing between Orkney and Shetland. Early build-up, but limited extension of the SIC, are features of recent mathematical models (Hubbard et al. 2009; Patton et al. 2016, 2017 ). Earlier suggestions that an initial phase of FIS glaciation on Shetland was followed by the build-up of a local ice sheet (Hoppe 1974; Mykura \& Phemister 1976) lack support on account of: (i) the scarcity of Scandinavian erratics; (ii) the absence of glacial transport of Permo-Triassic debris across the islands from basins located to the east; and (iii) the apparent absence of glacial deposits from the FIS, especially in zones of lower glacial erosion in the ice shed zone of the SIC and in western areas of the archepelago where MIS 5 deposits are preserved (Hall 2013). Furthermore, the tills on Shetland also appear to lack palynomorphs derived from sedimentary rocks and sediments in the northern North Sea basin (Fig. 4C). MSGLs along the margins of Yell Sound, between Yell and Mainland, and Bluemull Sound, between Unst and Yell (Fig. 4) (Golledge et al. 2008) are associated with distinctive mud-rich, grey tills (Chapelhowe 1965; Ross 1996) and probably record fast flow within SIC sourced ice from the heads of both sounds. Patterns of erratic dispersal and glacial lineaments at the northern and southern extremities of Shetland can be attributed to ice sheds off the present eastern coast (Ross 1996). Striae (Peach \& Horne 1879) and glacitectonic structures (Carr \& Hiemstra 2013) previously interpreted as indicating widespread onshore movement of ice in eastern Shetland are both considered by Hall (2013) to have been interpreted incorrectly.

The pattern of deglaciation around Shetland has become much clearer in recent years with the advent of detailed imagery of bedforms on the adjacent sea bed (Bradwell et al. 2008a). The SIC retreated back towards the spine of the islands from both $W$ and $E$, with moraines on Papa Stour marking a late stage of ice retreat into St Magnus Bay (Fig. 4) (Mykura \& Phemister 1976). Rogen moraines on the floor of the Pobie Basin, to the east of Unst, indicate ice retreat towards the south (Bradwell et al. 2008a), with moraines on Unst (Golledge et al. 2008) marking positions of the western flank of this retreating ice lobe.

\subsection{Orkney and Caithness}

More complex glacial sequences occur in Orkney and Caithness (Hall \& Whittington 1989; Gordon 1993a; Hall et al. 2011) from which a three-stage glaciation has been proposed 
recently for the last glacial cycle based on the preservation of stacked till sequences (Hall \& Riding 2016; Hall et al. 2016a) (Fig. 7A) (Table 3) (section 3.2.2).

The oldest features recognised in Caithness and Orkney are raised and intertidal rock platforms and associated rock cliffs buried by till (Crampton \& Carruthers 1914; Smith et al. 2018). On NW Hoy (Fig. 7A), raised beach gravels of the Muckle Head Gravel rest on a raised shore platform at 6-12 m OD and are overlain by periglacial slope deposits and a thin, brown, un-named till (Wilson et al. 1935; Sutherland 1993a). From Orkney Mainland northwards a mainly brown diamicton with few far-travelled clasts is found locally (Rae 1976). This Digger Till contains Carboniferous and Permian palynomorphs (Fig. 7A), which taken together with the evidence of striae (Fig. 7B), indicates deposition by ice that flowed to the NW from the platform E of Orkney. The overlying Scara Taing Till (Fig. 7A, 8) is a red to brown diamicton with locally high contents of marine shell fragments and a far-travelled clast component derived mainly from around the Moray Firth basin, but also including rock types typical of the Forth approaches (Carboniferous limestone and sandstone) and southern Fennoscandia (Fig. 9).

The uppermost, Quendale Till (Fig. 7A, 8), is a locally derived diamicton that records a final period of ice flow $\mathrm{N}$ and $\mathrm{W}$ across the low ground of the Orkney archipelago and offshore to the adjacent Atlantic shelf (Phillips et al. 2008: Hall et al. 2016a) (Fig. 7B). This event may correlate with an ice sheet readvance to the Reay Ridge, a sea-bed moraine lying $10-20 \mathrm{~km} \mathrm{~W}$ of Orkney Mainland (Bradwell \& Stoker 2015). The final retreat of ice is marked by moraine systems on the Atlantic shelf, on W Rousay (Fig. 9) and central Orkney Mainland, as well as by moraines and glaciolacustrine sediments in the valleys of western Hoy (Bradwell \& Stoker 2015; Hall 1996b; Hall et al. 2016a; Wilson et al. 1935). The pattern of retreat indicated by moraine ridges was SE across Orkney, into Scapa Flow (Fig. 9) and SSE towards the Moray Firth. This evidence clearly shows that an independent Orkney ice cap did not exist at this time (Hall et al. 2016a). Recalibrated cosmogenic exposure ages indicate that low ground on W Mainland became ice-free by c. 16 ka (Phillips et al. 2008; Ballantyne \& Small 2018.

The orientations of striae (Fig. 7B) together with the origin and distribution of glacial erratics (Fig. $9 \& 10$ ) suggest that ice flowed across Caithness and Orkney from the $S$ and $E$, out of the Moray Firth (Peach \& Horne 1880, 1881). The ice laid down mud-rich, shelly diamictons assigned to the Banffshire Coast, Caithness and Orkney Glacigenic Subgroup (Hall \& Riding 2016) (Fig. 3A). The occurrence of sparse Scandinavian erratics noted by Peach \& Horne $(1880,1893)$ on the northern isles of Orkney has been confirmed by Hall et al. (2016a) and on Fair Isle (Hall \& Fraser 2014) (Fig. 10). However, the palynomorph content of till matrices suggests that these indicator erratics are likely to have been reworked into Scottish tills from older sediments in the Outer Moray Firth and the Witch Ground basin of the central North Sea (Hall et al. 2016a) (Fig. 10). Hence there is no firm evidence that the FIS flowed over northern Orkney during the last glaciation. Instead, episodic development of fast ice flow between Orkney and Shetland is likely, sourced from an ice saddle that developed across the northern North Sea at the LGM (Sejrup et al. 2016). The Scandiinavian erratics may also derive from one or more earlier incursions of Fennoscandian ice into the western part of the northern North Sea (Flinn 1978). 
Recent numerical models (Hubbard et al. 2009; Patton et al. 2016, 2017 ) and ice sheet reconstructions (Clark et al. 2012) suggest the former existence of a local ice cap on Orkney, a possibility that was rejected in earlier stratigraphic studies (Wilson et al. 1935; Rae 1976). The very limited presence of far-travelled erratics, including marine shells, in Hoy and W Mainland and the absence or weak development of subglacial bedforms on the hills of Hoy is consistent with the build-up of a dome of cold-based ice of sufficient thickness to prevent incursion of Moray Firth ice into this part of Orkney for long periods. However, no till, striae or erratics have been reported that might relate to radial flow from an Orkney ice cap (Hall et al. 2016a). Instead, the ice flow indicators all point to ice flow across Orkney from an ice shed that lay to the E or SE , laying down the Quendale Till (Fig. 7b, 9,10) (see section 5.2).

In Caithness, aside from older glacial deposits found at depth (Tait 1912; Hall \& Whittington 1989) (Hall et al. 2018), the oldest till units attributed to the Late Devensian are the Ballantrath Till around Dunbeath (Gordon 1993b) and the Portskerra Till around Melvich (Hall et al. 2011) (Fig. 7A) (Table 3). The latter unit includes igneous and metamorphic clasts derived from the Sutherland-Caithness border, along with abundant Devonian sandstone and conglomerate debris, and records an early expansion of the NW Highland ice at least as far E as Watten (Omand 1973). At Wester Clett (also known as Drum Hollistan) (Gordon 1993c) (Fig. 7A) the Portskerra Till is overlain by cryoturbated gravel and by the lowermost of three calcareous, mud-rich till units of the Reisgill Burn Till Formation (Fig. 3B, 7A \& 11; Table 4) derived mainly from Devonian sedimentary rocks, but including shells, fossils and palynomorphs derived from the Moray Firth (Hall et al. 2011). This Drumhollistan Till Bed is overlain by a fan gravel and by the Eastern Gulley Till derived from the SE; it is also overlain by the Wester Clett Till derived from the S. Late advances of inland ice deposited younger till units and formed moraines on the surface of the Reisgill Burn Till in N and W Caithness. These probably were contemporaneous with a final advance of Moray Firth ice, which deposited the Wick Till (Fig. 7A) and moraine ridges on low ground bordering the Pentland Firth. MSGLs in Caithness (Hughes et al. 2010, 2014) conform to the main flow paths for the glaciers that laid down the Reay Burn Till (inland ice) and Reisgill Burn Till (Moray Firth ice) (Peach \& Horne 1881) (Fig. 3B), but the multiple events identified from units in both formations demonstrate that these subglacial landforms are composite products of multiple ice flow events following similar paths (Hall \& Riding 2016; Hall et al. 2016a).

3.2.1. Correlation of events on the Atlantic-North Sea divide. The reconstruction offered by Hall et al. (2016a) for the last glaciation of Caithness, Orkney and Shetland proposes ice flow both towards the Atlantic shelf edge and into the North Sea basin during three main phases, at 32-28, 24-18.5 and 17.5-16.2 ka (Fig. 12). In recent years, the local LGM in northern Britain has been placed in the first of these intervals (e.g., Bradwell et al. 2008a; Merritt et al. 2017a; Ballantyne \& Small 2018), yet the timing of the event elsewhere in NW Europe was generally coincident with the global LGM at $26.5 \mathrm{ka}$ to $19 \mathrm{ka}$ (Clark et al. 2009) (Fig. 1). The FIS margin was close to its southernmost limits in Europe during the periods 24.3-23.4 $\mathrm{ka}, 22.5-21.3 \mathrm{ka}$ and again from 20.3-18.7 ka (Toucanne et al. 2015). The FIS advanced into Denmark at 23-21 ka (Houmark-Nielsen \& Kjaer 2003). Peak IRD flux coincident with Heinrich Event 2 at $24 \mathrm{ka}$ is a feature of all records of the BIIS on its western margin (Scourse et al. 2009). The LGM on the West Shetland shelf also has been placed at 22-19.5 ka (Davison 2004), comparable to the mid-Norwegian shelf (Dahlgren \& Vorren 2003). A late 
LGM is consistent with cosmogenic isotope exposure ages on deglaciation of high ground (217-530 m OD) in Orkney, Caithness and Buchan, which occurred as late as $18.2 \pm 2.6 \mathrm{ka}$ (Ballantyne 2010).

Flow of the FIS across southern Shetland, Fair Isle and northern Orkney is also a recurrent feature of recent ice sheet reconstructions (Bradwell et al. 2008a; Graham et al. 2010; Sejrup et al. 2016). This interpretation mainly derives from: (i) a supposed connection between westward ice flow across northern Orkney and NW flow indicated by MGSLs in the Witch Ground basin; and (ii) the presence of Scandinavian erratics on northern Orkney and, probably, Fair Isle. Neither criterion, however, is secure. MGSLs are developed across the Coal Pit Formation and overlain by the Swatchway Formation; both sedimentary units include chalk debris (Graham et al., 2009; Davies et al., 2011), implying that erosion of the MGSLs was bracketed by phases of ice flow that crossed the chalk outcrop in the outer Moray Firth. The FIS also appears to have remained largely confined to the Norwegian sector of the North Sea basin during the last glaciation, heavily influenced by the Norwegian Trough (Sejrup et al. 2009). The extension of an ice stream from the SW flank of the Norwegian Channel to the North Atlantic shelf edge (Bradwell et al., 2008) is glaciologically implausible because the ice surface slope necessary to drive ice flow to the shelf edge gives an ice surface elevation offshore from southern Norway that is incompatible with the proximity of the southern LGM limit in Denmark (Phillips et al. 2017, fig. 3). As originally recognised by Graham et al. (2007), the MGSLs were probably cut by ice flowing to the SE out of the Moray Firth.

On northern Orkney, the very low concentrations of Scandinavian erratics are accompanied by larger numbers of erratics of Scottish origin in the Scara Taing Till (Hall et al. 2016a) (Fig. 8). Palynomorphs indicate that this till is of Scottish origin, deposited by ice passing through the Moray Firth (Peach \& Horne 1880). Hence it is likely that the Scandinavian erratics are reworked and part of complex patterns of erratic distribution on the Atlantic-North Sea divide (Fig. 10).

\subsection{Outer Hebrides}

The presence of erratics from the mainland in the Outer Hebrides indicates that at least parts of the archipelago were over-run by ice from the $E$ during the last glaciation (Geikie 1873, 1878; Sissons 1980). For example, clasts of Torridonian sandstone, Cambrian quartzite and also sedimentary rocks derived from the floors of The Minch and the Sea of the Hebrides basins are found on the S and W coasts of South Uist (Jehu \& Craig 1925), along the Sound of Harris and on the Flannan Isles (Stewart 1933) (Fig. 13). On NW Lewis, mainland erratics are abundant in deposits derived from The Minch (Baden-Powell 1938; von Weymarn 1979; Gordon 1993j). However, the presence of mainland erratics in a till that locally underlies the Ipswichian raised 'Galson Beach' on NW Lewis (Peacock 1984) (Fig. 14) indicates that this part of Lewis was over-run during an earlier glaciation (Hall et al. 2018).

Local Outer Hebridean erratics, striae and glacial lineations indicate that an independent ice cap developed over the Outer Hebrides during the LGM. The ice cap had divides located close to the $\mathrm{W}$ coast of the Uists, across the mountains of Harris and S Lewis and extending $\mathrm{N}$ towards the Butt of Lewis (von Weymarn 1979; Peacock 1984; Hall 1996a). Indeed, computer modelling of the last ice sheet suggest that independent ice masses developed on 
northern Lewis, the mountains of Harris and, later, the Uists, and subsequently coalesced (Hubbard et al. 2009; Patton et al. 2016, 2017). Ice streams developed in the Sounds of Harris and Barra, discharging ice from The Minch and the Sea of the Hebrides onto the North Atlantic shelf (Fig. 13).

The 'Galson Raised Beach' and its underlying raised shore platform at 4-10 m OD provides a valuable stratigraphic marker (Hall 1996a) (Table 5). The raised beach rests on organic deposits at Toa Galson (Gordon 1993i) (here renamed based on its location as Sgarbh Sgeir), which in turn rests on weathered till and rock (Sutherland \& Walker 1984). The beach gravel is cryoturbated north of Borve (Fig. 14), perhaps in more than one periglacial episode, and overlain by a single till unit derived from inland (Lewis Till Formation of Fig. 3B) (Hall 1995). The Galson raised beach has escaped glacial erosion beneath cold-based ice cover on NW Lewis (Hall 1995). To the N, on both coasts of the Butt of Lewis, the Galson Beach is overlain by a distinctive, interbedded sequence of glacigenic and water-lain sediments (Baden-Powell 1938; Gordon 1993i). These deposits, assigned to the Port Beag Till Formation were deposited by the Minch Palaeo Ice Stream (MPIS) crossing the northern tip of the island (Bradwell \& Stoker 2015b) (Fig. 13). The SW boundary of this formation (Fig. 3B) is marked by a large ridge, either a marginal moraine (Sutherland \& Walker 1984) or a wedge of sediment that accreted below a former shear margin within the ice sheet that separated warm-based, fast-flowing ice from sluggish cold-based ice (Bradwell \& Stoker 2015). Radiocarbon dates from marine shells in the sequence have yielded ages of 34.4-39.5 cal ${ }^{14} \mathrm{C} \mathrm{ka}$, which, if correct, imply episodic establishment of ice-free conditions in The Minch during the latter part of the Middle Devensian and a constraining maximum date for the ice advance that deposited these sediments (Sutherland \& Walker 1984; Small et al. 2017).

Stronger evidence for ice-free conditions prior to the last glaciation has been obtained from the northern side of Tolsta Head (von Weymarn \& Edwards 1973; Birnie 1983; Gordon \& Sutherland 1993b; Whittington \& Hall 2002) (Fig. 13 \& 15). The organic sediments preserved at Tolsta Head have been dated to $38-32 \mathrm{cal}{ }^{14} \mathrm{C}$ ka and contain an important record of dominantly open grassland vegetation during the 'Tolsta Interstadial' of MIS 3 (Whittington \& Hall 2002) (Table 4). Variations in palaeotemperature inferred from the pollen assemblages and sedimentology are provisionally matched by these authors with GI8 to GI-5 (Fig. 2). The overlying Port Beag Till is a brown, matrix-supported, silty, sandy diamicton, with crude sub-horizontal structure. Clasts are predominantly Lewisian gneiss, but include hard, siliceous brown sandstones probably derived from the Torridonian inlier on the Shiant East Bank Ridge (von Weymarn \& Edwards 1973; Whittington \& Hall 2002) that lies some $40 \mathrm{~km}$ SE of Tolsta Head (Chesher et al. 1983). Von Weymarn \& Edwards (1973) reported that the till fabric showed a dominant NW clast orientation that corroborates deposition by ice flowing from the SE, but striae inland of Tolsta Head trend EW (Peacock 1981). The till was probably deposited within a zone of shifting ice flow where local Lewis ice bordered the western flank of the MPIS, which laid down a thick sequence of glacially overridden and tectonised diamictons, sands and gravels, with fragmented marine shells (Bradwell \& Stoker 2015b). Broadly equivalent deposits occur on the Eye Peninsula (Sutherland \& Walker 1984) (Fig. 13). 
The outlying islands of St Kilda (Fig. 13 \& 16) occupy a key location for understanding the extent of the last ice sheet on the Hebridean shelf (Sutherland et al. 1982). Earlier work on Hirta identified an older, weathered diamict, the Ruaival 'Drift', assigned to a phase of local glaciation before the Late Devensian, and a younger till, the Village Bay Till, deposited by cirque glaciers on Hirta during the Late Devensian (Sutherland et al. 1984). The Abhainn Ruaival organic bed, radiocarbon-dated to 24.7 ka BP (SRR-1809b), occurs beneath the Ruaival Head, one of two units of periglacial slope deposit seen to lie between the two tills. The palynology of the organic bed indicates the establishment of a species-poor grassland with virtually no shrub cover under interstadial conditions (Sutherland et al. 1984; Walker 1984). The bed is tentatively assigned to the 'Tolsta Interstadial' (Hiemstra et al. 2015), but the pollen record differs from that for the same interval at Tolsta Head, on Lewis, where Fagus and Picea are absent (Whittington \& Hall 2002). Hiemstra et al. (2015) suggest returning to the earlier, simplified interpretation of the stratigraphy on Hirta (Wager 1953), challenging whether the Ruaival Drift is a glacial deposit.

Small erratic clasts of red sandstone and heavy minerals derived from Lewisian gneisses occur in the oldest till units recorded on St Kilda (Sutherland et al. 1984). The source of the sandstone is probably the Flannan Trough, lying 35-50 km to the $E$, which is floored by red brown Permo-Triassic sandstone (Stoker et al. 1993). The heavy minerals are likely derived from the extensive submarine platform formed by Lewisian rocks E of St Kilda (Stoker et al. 1993). The last ice sheet glaciation of St Kilda probably occurred before MIS 5e (Sutherland et al. 1984; Hiemstra et al. 2015), consistent with the presence of large tors and pinnacles on ridges down to $<100 \mathrm{~m}$ OD on Hirta (Fig. 16 ). Any more recent passage of fast-moving, erosive ice should have been capable of removing or modifying these fragile landforms. Recently acquired cosmogenic isotope ages support the conclusion that St Kilda supported only locally sourced glaciers during the LGM (Ballantyne et al. 2017). However, this interpretation contradicts the view that the last ice sheet terminated to the west of the archipelago at, or near, the Atlantic shelf edge (Bradwell et al. 2008a; Chiverrell \& Thomas 2010; Gibbard \& Clark 2011; Clark et al. 2012),

\section{Core areas}

Considerable research has been undertaken in the NW and Central Highlands since the review by Sutherland (1993b). Both regions were centres of ice accumulation beneath which older deposits have been preserved locally due to relatively little subglacial erosion.

\subsection{NW Highlands}

The ice that flowed from an ice divide situated over the NW Highlands deposited tills, outwash and glaciolacustrine deposits assigned to the North-west Highlands Glacigenic Subgroup (Auton 2003; Bradwell 2003; McMillan et al. 2011a) (Fig. 3A).

Three formations have been recocognised to the $\mathrm{W}$ of the main $\mathrm{N}-\mathrm{S}$ watershed following recent onshore and offshore mapping (Bradwell 2003, 2010a; Stoker et al. 2009; Bradwell \& Stoker 2010), namely the Loch Broom Till, Assynt Glacigenic and Ullapool Gravel formations. To the $\mathrm{E}$ of the watershed, in eastern Sutherland and Caithness, the Reay Burn Till and Dunbeath Till formations also form part of the subgroup (Auton 2003) (Section 3.2) (Fig. 3B). The Loch Broom Till has been mapped alongside, and beneath Loch Broom and Gruinard Bay 
and is interpreted as a subglacial traction till that was deposited by the MPIS (Fig. 13). The till has a streamlined surface morphology with lineations trending NW.

The Assynt Glacigenic Formation comprises clast-rich to clast-supported diamictons interbedded with sands and gravels. It is distributed discontinuously to the $\mathrm{W}$ of the main watershed, extending offshore, and includes well-developed, nested moraine ridges (Stoker et al. 2009; Bradwell \& Stoker 2010). Several geographically distinct members have been recognised associated with late-stage glacier oscillations, namely the Allt na $h$-Airbhe Member (predominantly offshore), and the Allt an t-Srathain, Rhiroy and Glen Douchary members. The last of these occurs within the ice limits correlated with the Loch Lomond Stadial in the region (Ballantyne 2018). The Ullapool Gravel Formation includes glaciofluvial fan, deltaic and outwash deposits that formed during high relative sea levels around Ullapool, along margins of Loch Broom and adjoining sea lochs, and locally along the coast of the NW Highlands (Stoker et al. 2009; Bradwell 2010b). It is assigned to the Windermere Interstadial.

The tills of the NW Highlands typically contain clasts derived from local crystalline metamorphic and igneous rocks, Cambrian quartzites and Torridonian sandstones, but observations on the dispersal of sparse indicator erratics are revealing. For example, Cambrian Pipe Rock is found from NW Lewis to Hoy and into Moray, indicating that the ice shed once straddled the outcrop of this distinctive rocktype in Assynt (Sutherland 1984) (Fig. 13). The location of the ice shed is also suggested by the general distribution of erratics of 'Carn Chuinneag-Inchbae augen gneiss' (Fig. 17), which are found across Easter Ross and from Elgin eastwards towards Buchan (Sissons 1967a; Peacock 1970). However, these distinctive erratics also occur along Loch Broom, implying that the ice shed once lay east of the outcrop of the gneiss in Easter Ross, requiring a very different ice sheet configuration. Interestingly, in the ice-sheet model of Hubbard et al. (2009) the ice shed is located over the coastal hills of Sutherland and Easter Ross for a time during the last glaciation, at 29.4 ka.

The significance of the region as an ice dispersal area has been enhanced by the recognition of the MPIS, which was fed by a number of tributaries sourced in the mountains of Kintail, Wester Ross, Assynt and Sutherland (Stoker \& Bradwell 2005; Bradwell et al. 2007) (Fig. 13). Geomorphological mapping based on NEXTMap imagery has elucidated the role of glaciation in shaping the landscape (Lukas \& Bradwell 2010). For example, multiple cycles of glacial erosion during the Pleistocene have removed pre-existing regolith and decomposed bedrock along the western fringe to form extensive ice-scoured, 'cnoc-andlochain' topography (Sissons 1967a; Krabbendam \& Bradwell 2014). Most notably, smooth, sub-parallel linear furrows and flutes in bedrock have been identified as 'megagrooves' (cf. Goldthwaite 1979; Bradwell 2005; Bradwell et al. 2007, 2008b; Krabbendam et al. 2016). Another swathe of megagrooves, whalebacks and rock drumlins has been identified to the east of the former regional ice divide in the valley of the River Endrick (Fig. 17 \& 18), north of the Great Glen (BGS 2012. These features are likely to be the legacy of a former topographically unconstrained ice stream within the last ice sheet that flowed NE towards the Moray Firth basin (Merritt et al. 2013; Hughes et al. 2014).

The caves of the Allt nan Uamh and Traligill valleys in Assynt, including the so-called 'Bone Caves' of Inchnadamph (Fig. 13), provide critical evidence for Quaternary landscape 
evolution and chronology in the region (Hebdon et al. 1997) (Table 6). Further investigations since the review by Lawson (1993) have provided new information on the cave sediments, faunal remains and chronology (Lawson 1995a, b, 2010; Lawson \& Atkinson 1995; Kitchener \& Bonsall 1997; Lawson et al. 2014). Uranium disequilibrium series dates on speleothems indicate ice-free conditions during the last (MIS 5e) interglacial, between 95-56 ka, at c. 38 ka and between 30 and 26 ka (Lawson 1995a; Lawson \& Atkinson 1995). Radiocarbon dates on faunal remains (reindeer and brown bear) also imply that at least parts of the area were ice-free between $\sim 50-\sim 77 \mathrm{cal}{ }^{14} \mathrm{C}$ ka BP and between $\sim 36-\sim 26 \mathrm{cal}{ }^{14} \mathrm{C}$ ka BP (Lawson 2010; Lawson et al. 2014). Contrary to other evidence (Section 2), these dates appear to preclude extensive glaciation in the NW Highlands during the Early Devensian (particularly during MIS $5 \mathrm{~b}$ and $5 \mathrm{a}$ where there is a cluster of dates) and conflict with interpretations of early buildup of the last ice sheet and its maximum extent on the Atlantic Shelf between 30 - $27 \mathrm{ka}$ (Bradwell et al. 2008a; Ballantyne \& Small 2018).

During deglaciation, the 'Wester Ross Readvance' produced a series of end and lateral moraines between Applecross and Achiltibuie (Ballantyne et al. 2009a; Ballantyne \& Small 2018) (Fig. 13). Recalibration of earlier terrestrial cosmogenic nuclide age estimates places this event at $15.3 \pm 0.7 \mathrm{ka}$ at the beginning of the Last Glacial-Interglacial Transition (Ballantyne \& Small 2018). On the E side of the ice divide, an oscillation of the ice sheet margin is indicated by a currently undated moraine system alongside Loch Shin (Lukas 2010) (Fig. 13).

\subsection{Central Highlands}

The Pleistocene deposits in upper Strathspey (Fig. 17), the middle reaches of the Findhorn and to the $\mathrm{W}$ of the Pass of Drumochter have been assigned to the Central Highland Glacigenic Subgroup (Fig. 3A). The eastern boundary of this subgroup divides those areas affected by ice flowing from the main N-S ice divide of the last ice sheet, situated over the western Highlands, from mountains affected by locally sourced ice, notably the Cairngorms and Gaick (British Geological Survey 2008a \& b, 2013) (Fig. 3A). The oldest known glacigenic unit in the sequence is the Pattack Till, which most probably antedates the last interglacial (MIS 5e) judging by its weathered condition (Hall et al. 2018) (Table 7). It is locally overlain by the Ceardaich Sand and Gravel, which was deposited as glaciofluvial outwash during an early stage of the last glaciation when ice advanced eastwards up reverse-draining valleys (Merritt 1999; British Geological Survey 2002). Deltaic glaciofluvial sequences locally fine downwards into laminated clay and silt with sparse lonestone pebbles (Linn of Pattack Silt). Similar sequences occur to the S of the Gaick plateau, where sections displaying till-capped fine-grained sediments correlated with the Linn of Pattack Silt Formation indicate that ice first blocked the lower reaches of southward draining valleys, causing ponding, before it overrode the deposits from the $W$ and impinged against the plateau (Merritt 2004a). No evidence for an early expansion of ice from the Gaick has been reported, but granite-rich till derived from the Cairngorms is locally overlain by psammite (metasandstone)-rich till derived from the $\mathrm{W}$ recording an early expansion of Cairngorm ice (Barrow et al. 1913; British Geological Survey 2013).

The laminated deposits of the Linn of Pattack Silt Formation typically have been deformed into glacitectonite (sensu Benn \& Evans 2010) at the base of the overlying Ardverikie Till (Merritt 1999). The latter includes most surficial tills in the region and is typically a stony 
diamicton with boulders of grey porphyritic granodiorite from the Rannoch area in addition to locally-sourced psammitic rock types (Fig. 3B) (McMillan et al. 2011a). The Ardverikie Till extends $\mathrm{N}$ across the Spey - Findhorn catchment divide where it commonly overlies very sandy diamicton of the Inverness Glacigenic Subgroup (Horne \& Hinxman 1914) (Fig. 3B). The Ardverikie Till is correlated with the Beinn an Uain Till at the Dalcharn and Moy sites east of Inverness (Fig. 3B \& 17) (Section 5.1).

Northward flow of ice across the Spey-Findhorn divide is indicated by streamlined subglacial bedforms (Hughes et al. 2014), the orientation of glacial striae, the clastcomposition of the surficial till units (Fletcher et al. 1996) and the dispersal of erratics of Cairngorm Granite towards Lochindorb (Sutherland 1984). The northward flow was concentrated within a narrow corridor of strongly glacially modified terrain centred on Lochindorb, whereas the landscape to either side, and particularly to the east, appears to have experienced relatively little cumulative glacial modification (Hughes et al. 2014; Merritt et al. 2013, 2017b) (Fig. 17). Evidence for strong northward flow towards the corridor includes clusters of large-scale ('mega') crag-and-tail features in the lower Dulnain valley, W of Grantown-on-Spey (Young 1977b; British Geological Survey 2013) and mega-scale roches moutonnées (Creagan a' Choin and Ordan Shios), 25 km SW of Aviemore (British Geological Survey 2008b; Merritt et al. 2013; Merritt 2017a).

The absence of far-travelled erratics within the Cairngorms and eastern Gaick indicates that local ice caps had developed there before the district became overwhelmed by ice sourced from the W (Bremner 1929; Sugden 1970; Gordon 1993h). The Cairngorms were entirely buried beneath ice, based on evidence of lee-side joint-block removal, glacially transported tor blocks and stripping of blockfields at elevations of up to $1200 \mathrm{~m}$ (Hall \& Glasser 2003; Phillips et al. 2006). Ice flowed against the Cairngorm massif, where it was deflected by local cold-based ice (Sugden 1968; Sutherland 1993e; Hall \& Sugden 1987), but probably penetrated eastwards into the catchment of the River Dee (Barrow et al. 1913; Merritt et al. 2004b; Merritt 2004b). Cairngorm ice apparently re-occupied the uppermost catchment of the Dee during deglaciation following the retreat of ice sourced from the west (Merritt 2004, fig. 24).

A topographically-constrained corridor of relatively fast-flowing ice (ice stream) centred on upper Strathspey probably operated late in the LGM at the time when ice was flowing northwards across the Spey-Findhorn divide, via the narrow 'Beum a' Chlaidheimh Breach' and Lochindorb (Merritt et al. 2017a, b) (Fig. 17). Considering the elevation of the breach at $360 \mathrm{~m}$, ice is likely to have stopped flowing across the divide soon after deglaciation of the Cairngorm tops, which commenced at c. 21.3 ka (Phillips et al. 2006) (Table 7). A recalibrated mean cosmogenic age of 18.2 ka (Ballantyne et al. 2009b; Ballantyne \& Small 2018) for rockslide debris suggests early deglaciation in Strath Nethy, in the NW Cairngorms. After ice became too thin to flow across the divide, a huge outlet glacier became established in upper Strathspey. Recent cosmogenic dating of boulders on an ice-marginal moraine in Rothiemurchus, a large depression lying to the $\mathrm{W}$ of the Cairngorms, suggests that the Strathspey glacier was still active and readvancing at c. $15.1 \mathrm{ka}$ (Hall et al. 2016b). Widespread ponding occurred during and following the decoupling of local Cairngorm glaciers from the Strathspey glacier sourced in the west (Brazier et al. 1998). This was associated with the aggradation of glaciofluvial fans and deltas on the southern flanks of the 
Spey-Findhorn divide at elevations of 300-350 m OD (Merritt et al. 2013). Meltwaters carrying clasts of Old Red Sandstone (ORS) lithologies flowed southwards through a deep channel on the divide, at Slochd Mòr. They were then deflected eastwards along the margin of the outlet glacier in Strathspey before flowing back northwards across the divide through the Beum a' Chlaidheimh Breach (British Geological Survey 2013; Merritt 2017a) (Fig. 17).

There is abundant evidence, such as glacial drainage channels on the valley flanks, for the retreat of the Strathspey outlet glacier (Young 1974, 1975a, b, 1977a, b, 1978; British Geological Survey 2004, 2013; Merritt et al. 2013). Some ice-marginal channels and benches are intimately associated with lateral moraine ridges, and evidence from Raitts Burn, $16 \mathrm{~km}$ SW of Aviemore (Phillips \& Auton 2000, 2013; Phillips et al. 2007), indicates that the glacier remained active during its retreat towards Loch Etteridge, $8 \mathrm{~km}$ E of Laggan (Fig. 13), an important late-glacial site that had become free of ice by $15.6 \mathrm{cal}{ }^{14} \mathrm{C}$ ka BP (Lowe et al. 2008a; Ballantyne et al. 2009; Ballantyne \& Small 2018). Meltwaters were firstly ponded behind temporary barriers of stagnant ice and glacial sediment in the Middle Findhorn during deglaciation, before being constrained to follow the present axis of the valley towards the coast (Bremner 1939; Auton 1990, 1998, 2017a, b). In contrast, much of the meltwater from decaying ice in the upper reaches of the Findhorn Valley drained NW into the Nairn valley, depositing broad spreads of kettled outwash sand and gravel around Moy (Fletcher et al. 1996; British Geological Survey 1997; Merritt et al. 2017b) (Fig. 17)

\section{Lowland depocentres}

\subsection{Inverness and Moray}

This region, lying between the Inverness area and the mouth of the River Spey, E of Elgin, includes two of the few sites in Scotland at which organic material has been assigned to the Ipswichian Interglacial (Sutherland \& Gordon 1993c; Hall et al. 2018, fig 13; Table 8). At Dalcharn, 15 km E of Inverness, the Dalcharn Palaeosol Formation (Fig. 17, 19) contains compressed and disseminated organic material that includes pollen of full interglacial affinity reflecting the middle and later stages of an interglacial cycle (Walker et al. 1992; Auton 1993; Merritt \& Auton 2017). The organics appear to be relatively unweathered, but they rest on the Craig an Daimh Gravel, which is substantially decomposed, indicating that it has been subjected to prolonged weathering under warm, humid conditions. The pollen record indicates that closed pine forest with birch, alder and holly was succeeded by pineheathland, which was replaced initially by birch and later by heath and open grassland (Walker et al. 1992). As the Dalcharn site lies near to the present northern limit of holly in Britain the relative abundance of Ilex pollen in the profile almost certainly reflects a climate somewhat warmer than that of today. The pollen assemblage is similar in some respects to that described from Fugla Ness, on Shetland (Section 3.1), which was originally equated with the Gortian of Ireland (Birks \& Ransom 1969), and hence with the Hoxnian of southern Britain. However, samples of sandy matrix collected from a unit of white, cryoturbated gravel taken from beneath the uppermost organic part of the palaeosol at Dalcharn have yielded maximal luminescence ages of 68 and 50 ka (Duller et al. 1995). The ages are not at variance with an infinite radiocarbon date of $>41.3{ }^{14} \mathrm{C}$ ka BP obtained from a bulk sample of the organic unit above, but suggest that the thermophilous arboreal pollen in the palaeosol must be either allochthonous (Whittington 1990) or reworked. 
At another important site at Teindland (Fig. 17), near Elgin, where a preserved section reveals a truncated podzolic soil, the Teindland Palaeosol contains pollen of thermophillous species and grasses and has also been assigned to the latter part of the Ipswichian Interglacial (Sutherland 1993c; Hall et al. 1995a; Hall et al. 2018, fig. 21). Luminescence ages of around 79 and $67 \mathrm{ka}$ obtained by Duller et al. (1995) from the Badentinian Sand Bed (Table 9) above the main organic horizons support the age suggested. Although the genesis of the overlying Woodside Diamicton is unclear, the presence of an isoclinal fold and shear zones within the sand bed strongly suggests post-depositional glacitectonism (Merritt et al. 2003; E.R. Connell \& E.R. Phillips, unpublished). It follows that the uppermost part of the sand may have been eroded and thus the Thermoluminescence (TL) dates could significantly predate the initial glaciation of lower Strathspey during the last glacial cycle. However, the simplest interpretation would suggest that glaciation occurred soon after its deposition (Table 8).

A compressed bed of fibrous peat was discovered beneath till at the Allt Odhar site on the Moy estate, some $16 \mathrm{~km}$ SE of Inverness, at $371 \mathrm{~m}$ OD (Walker et al. 1992; Merritt 2017b) (Fig. 20). This Moy Peat Formation contains pollen, plant-macrofossils and coleopteran remains that reveal climatic deterioration towards the end of a cool interstadial as reflected in the replacement of birch woodland and willow scrub with grassland and heath, and then by open communities of grass and sedges (Walker et al. 1992). An Early Devensian MIS $5 d$ or $5 b$ age is not at variance with three infinite radiocarbon age determinations ( $>51.1{ }^{14} \mathrm{C}$ ka BP) (Walker et al. 1992), nor with an experimental U-series disequilibrium measurement of 106 ka for the peat (Heijnis \& van der Plicht 1992). However, samples collected from sand-rich lenses within the peat unit subsequently have yielded luminescence ages of between 37 and $58 \mathrm{ka}$ (Duller et al. 1995). These ages are consistent with a single finite radiocarbon age of $47.7{ }^{14} \mathrm{C}$ ka BP obtained from the alkali insoluble component of samples of the peat (Walker et al. 1992). The time span of $20 \mathrm{ka}$ between the TL ages for the top and bottom of the peat is difficult to accept, but not totally at variance with the entomological palaeoenvironmental evidence. On reflection, a Middle Devensian age is possible, especially as pollen grains of Bruckenthalia spiculifolia (Balkan heath) are not recorded (M.J.C. Walker pers. comm. 2017). This species has been reported from Early Devensian interstadial deposits in NE Scotland (Whittington 1994) (section5.2), although at much lower altitudes.

The Ipswichian biogenic deposits at Dalcharn (Fig. 19) and the Early (or Middle) Devensian interstadial peat unit at Allt Odhar (Fig. 20) are overlain by the sandstone-rich Athais Till Formation of the Inverness Glacigenic Subgroup, which has a fabric indicating ice flow towards the SE (Walker et al. 1992; Auton 1993; Merritt 1993; Merritt et al. 2017a; Merritt 2017b). The distribution of other concealed sandy diamictons of this subgroup (Fig. $3 A$ ) suggests that during a relatively early phase of the last glaciation, if not before, ice flowed across the Great Glen towards the ESE, against the north-facing slopes of the Inner Moray Firth (Sutherland \& Gordon 1993c; Fletcher et al. 1996). The ice carried sandstone, siltstone and conglomerate from ORS outcrops around Loch Ness eastwards towards Grantown-on-Spey onto ground up to at least $500 \mathrm{~m}$ OD on the Nairn-Findhorn watershed and into the middle to lower reaches of the Nairn, Findhorn and Spey valleys (Hinxman \& Anderson 1915; Horne 1923; Sutherland \& Gordon 1993d; Merritt et al. 2017b) (Fig. 17). 
The sandy Athais Till is generally overlain by psammite-rich till (Beinn an Uain Till Formation) deposited by ice flowing NNE (Fletcher et al. 1996). Following the systematic logging of numerous natural sections E of Inverness, Merritt \& Auton (1993) found that the contact between the sandstone-rich and overlying psammite-rich till was generally represented by a sharp change in colour and commonly by a planar discontinuity suggestive of a hiatus in aggradation. However, no major unconformities, distinct weathering profiles, palaeosols or organic deposits were found at the boundary indicating deglaciation, although the presence of downward-tapering, wedge-shaped pull-apart structures, truncated gravel-filled channels, seams of glacitectonite and rip-up clasts of diamicton suggest that ice-bed boundary conditions changed during the switch in flow (Fletcher et al. 1996). At Dalcharn, till fabrics reveal that ice flow first swung around to the E before heading NNE (Walker et al. 1992) (Fig. 19). This inferred direction of flow suggests that the uppermost till unit at Dalcharn was deposited when ice flowed directly towards the Moray Firth basin across the Spey-Findhorn divide from centres positioned over the Cairngorms and western Highlands (Fig. 17) (Hughes et al. 2014; Merritt et al. 2013). Both the sandstone- and psammite-rich till units could be Middle to Late Devensian in age if the youngest luminescence age at Moy (37 ka) is accepted (Duller et al. 1995; Merritt et al. 2017a) (Table 8).

At Clava, in the Nairn valley (Fig. 17), there is an important, well-documented site long known for discoveries of 'arctic' shelly clay and shelly diamicton (Gordon 1993e; Merritt 1992; Merritt \& Phillips 2017). At elevations of 150 m OD the Clava Shelly Clay contains well preserved, high-boreal to low-arctic, shallow-water marine shells that have yielded amino acid racemisation (AAR) ratios not younger than the Middle Devensian (Merritt 1992). Furthermore, an associated folded raft of pebbly diamicton (Clava Shelly Till) containing fragments of Portlandia arctica, an indicator of shallow-marine, fully arctic conditions, yielded a radiocarbon age of $>47.1 \mathrm{cal}{ }^{14} \mathrm{C} \mathrm{ka} B P$. These sediment units are now accepted to be glacial rafts transported eastwards from the Loch Ness basin (Fig. 17), which was probably a marine fjord during the Middle Devensian (Merritt 1992; Phillips \& Merritt 2008; Merritt et al. 2014). The rafts are overlain by the Finglack Till Formation, which was laid down by NE-directed ice that flowed towards the Inner Moray Firth, forming elongated subglacial landforms of this orientation (Hughes et al. 2014, flow-set 6) (Ballantyne \& Small 2018, fig. 4). The sandy Finglack Till crops out around Inverness, Nairn, Forres and across the Black Isle (Fletcher et al. 1996) (Fig. 3B).

Evidence of generally falling relative sea levels around Inverness during deglaciation is preserved in flights of raised late-glacial shorelines lying up to about $30 \mathrm{~m}$ OD around the inner Moray Firth (Firth 1989; Firth \& Haggart 1989; Smith et al. 2018). These shorelines truncate widespread deposits of glaciofluvial outwash, silt and clay to the E of Inverness assigned to the Alturlie Gravels and Ardersier Silts formations, respectively (Fletcher et al. 1996; British Geological Survey 1997). These raised deposits, which are interpreted to be glaciomarine in origin on account of the cyclic sedimention they commonly display, were laid down in front of an active outlet glacier that flowed into the Inner Moray Firth (Merritt et al. 1995). The Ardersier Silts were deformed during a substantial readvance that formed a push moraine on the Ardersier peninsula and a capping of diamicton (Baddock Till Member) (Merritt et al. 1995; Fletcher et al. 1996; Merritt \& Firth 2017; Merritt et al. 2017b). A tidewater fan-delta (Bothyhill Gravel Member) formed during a subsequent stillstand at Alturlie Point (Fletcher et al. 1996; Merritt et al. 1995, 2017c). These glacial oscillations, and 
an earlier one that formed a possible push moraine at Grange Hill, between Forres and Kinloss (Auton 2017c), are currently undated. They probably result partly from the competing strengths of ice flowing from the Great Glen and through the Beauly Firth basin, and partly from the delicate interplay between contemporary rates of global sea-level rise and local glacio-isostatic uplift (Merritt et al. 1995; Smith et al. 2018).

The results of recent geophysical surveys and lake-bed sampling in Loch Ness suggest that the frontal margin of the Ness Glacier terminated in water throughout its retreat (Turner et al. 2012). The glacier initially had a lightly grounded or possibly floating ice shelf, forming a series of low, cross-valley ridges on the lake bed. It had become fully grounded by Foyers (Fig. 17), where a major moraine ridge was formed during a stillstand. The subsequent retreat of the glacier was dynamic and punctuated by minor stillstands and oscillations that formed smaller moraines beneath the loch.

\subsection{NE Scotland}

A comprehensive, critical review of the complex lithostratigraphical and geomorphological record of the last glaciation of NE Scotland (River Spey around Buchan to Montrose) has been given by Merritt et al. (2017a) and so is not repeated here in detail. Descriptions of the sites in the region that are mentioned below and that have provided important stratigraphical information are given by Sutherland \& Gordon (1993a) and Merritt et al. (2003,

http://earthwise.bgs.ac.uk/index.php/Cainozoic geology and landscape evolution of nor th-east Scotland).

The informal lithostratigraphic 'series' of glacigenic deposits in NE Scotland established by Sutherland (1984) and Hall \& Connell (1991) have been replaced by more formal subgroups (McMillan et al. 2011a) (Fig. 3A). The 'blue-grey series' of Synge (1956), renamed as the Banffshire Coast, Caithness and Orkney Glacigenic Subgroup, relates to a suite of generally thickly developed diamictons, sands and gravels laid down by ice that flowed onshore from the Moray Firth (Fig. 21). The 'red series' of Jamieson (1906) and Synge (1956) formed of generally thickly developed reddish brown diamictons, sands and gravels has been subdivided. This is in order to separate the typically more vivid reddish brown diamictons, sands, silts and gravels that were laid down by ice that encroached onshore from the North Sea basin (Logie-Buchan Glacigenic Subgroup), from those that were derived entirely from ice flowing NE along Strathmore (Mearns Glacigenic Subgroup). The 'inland series' of Hall (1984) comprising generally thin, very sandy and commonly weathered diamictons, sands and gravels has become the East Grampian Glacigenic Subgroup.

NE Scotland, and particularly Buchan (Fig. 21), includes several sites that are important for understanding pre-Devensian events (Hall et al. 2018). At the Kirkhill and Leys sites (Fig. 21) the truncated Fernieslack (Kirkhill Upper) Palaeosol Bed (Hall et al. 2018, fig. 14) is assigned to the Ipswichian following TL dates on sediments underlying it (Duller et al. 1995) (Table 10 \& 11). Early Devensian stadial/interstadials recording fluctuating cool and colder environmental conditions may be represented at the Camp Fauld and Crossbrae sites in Buchan (Fig. 21) (Whittington et al. 1993; 1998; Merritt et al. 2003). Elsewhere, the Burn of Benholm Peat Bed at the Burn of Benholm, S of Inverbervie (Fig. 21), is also now correlated tentatively with MIS $5 \mathrm{c}$ on the basis of the presence of pollen of the Balkan heath, 
Bruckenthalia spiculifolia, which occurs at Camp Fauld and Crossbrae (Whittington 1994; Auton et al. 2000). At Benholm, the erratics within the shelly, clayey diamicton (Benholm Clay Formation) that underlies the peat bed indicate that it was laid down by ice flowing onshore from the North Sea basin, probably during MIS 6 (Merritt et al. 2003; Hall et al. 2018).

The last ice sheet witnessed abrupt changes in ice flow direction and geometry (Hughes et al. 2014), but the peripheral location of this area in respect to accumulation centres in the $\mathrm{W}$ and NW probably resulted in large sectors remaining cold-based for long periods. This is suggested by palimpsest periglacial features (cf. Kleman 1994) preserved in central Buchan, where the stratigraphical record is longest (Connell \& Hall 1987; Hall et al. 2018).

It has been suggested that much of Scotland was glaciated during the Early Devensian (MIS 4) (Sutherland 1981) and Hibbert et al. (2010) have recorded contemporaneous icerafted debris with a Scottish provenance in the offshore Barra-Donegal Fan (Hall et al. 2018, fig. 1) implying a marine-terminating ice sheet during this period. However, with the possible exception of the Woodside Diamicton at Teindland (Hall et al. 1995a) (Table 8), no tills in the region can be confidently assigned to this glacial event, including the Hythie Till (Kirkhill Upper Till) (Hall \& Jarvis 1993a), and the Pitlurg Till, at Bellscamphie, near Ellon (Hall \& Jarvis 1993b, 1995) (Fig. 21). Several sites probably include a record of this period in the form of periglacial phenomena; for example, the Corsend Gelifluctate Bed at Kirkhill (Table 11) (Hall et al. 2018, figs. 16 \& 18). At Oldmill, in Buchan, and Nigg Bay, immediately S of Aberdeen, clastic sediments have yielded luminescence (OSL) age estimates of 74+/-6 ka and 63+/-7 ka, respectively (Merritt et al. 2003). This suggests, if correct, that the dated glaciodeltaic deposit at Oldmill (truncated and capped by a periglacial landsurface displaying ice-wedge casts) and upwards fining outwash sediments at Nigg Bay may represent terrestrial evidence of an MIS 4 ice sheet (Gemmell et al. 2007). At both sites these sediments are overlain unconformably by complex suites of tills, sands and gravels believed to date to later Devensian events (Merritt et al. 2017a).

There are now no known representative organic deposits of Middle Devensian interstadials in the region. The Crossbrae Peat at Crossbrae, near Turriff (Fig. 21) was originally thought to date from between 22 and $26.5{ }^{14} \mathrm{C}$ ka BP, but it is now correlated with MIS 5a or 5c (Whittington et al. 1998). The apparent absence of Middle Devensian deposits may be explained if the region was ice-covered during this period of time. Indeed, this scenario is suggested by evidence obtained from the gravel pit at the Howe of Byth, near New Pitsligo (Fig. 22), at which the Howe of Byth Gravel has yielded luminescence ages of between 45 and 38 ka (Duller et al. 1995; Hall et al. 1995b). As this gravel unit is interpreted to have been laid down by glacial meltwater (Hall et al. 1995b; Hall \& Connell 2000), ice had possibly reached the northern coast of Buchan at this time.

Twelve stages in the evolution of the last BIIS in NE Scotland during the Middle to Late Devensian have been recognised by Merritt et al. (2017a) (Table 10; Fig. 23) and are summarised below. Stages 1 to 5 are established mainly from a parsimonious interpretation of the lithostratigraphical record at a few key sites, whereas stages 6 to 12 are linked to retreat stages based on the geomorphological record, both onshore and offshore, identified by Clark et al. (2012) and Hughes et al. (2014). The evidence for each stage is presented fully 
as 'Supporting Information' in Merritt et al. (2017a), however, problems remain regarding the published geochronometry for the region, particularly the integration of ages produced by different dating methods and of adjustments and recalibrations that have been made to them.

At least three 'binge-purge' cycles (cf. Alley \& MacAyeal 1994) occurred during the last glaciation of Scotland (Hubbard et al. 2009; Patton et al. 2016, 2017) (Fig. 12) and appear to be represented in the stratigraphy of NE Scotland (Merritt et al. 2017a) (Table 10). The 'binge' phases resulted in very limited, patchy subglacial erosion and till deposition, but were conducive to the initiation, transport and preservation of glacial rafts, which are unusually common along the Banffshire coast and in Buchan (Peacock \& Merritt 1997, 2000; Merritt et al. 2003; Merritt \& Connell 2000). The relatively short 'purge' phases dominate the subglacial geomorphological legacy, in terms of the number of distinct flowsets that have been recognised (Hughes et al. 2014), and appear to be more fully represented in the stratigraphical record through deposition of till.

5.2.1. Stage 1. An extensive, early, ESE-directed flow of ice from the Great Glen and the western Highlands has been deduced to have occurred to the $W$ of the Spey across ground rising to at least $500 \mathrm{~m}$ OD (Fletcher et al. 1996) (Fig. 23.1) (Section 5.1). Several sites in NE Scotland preserve stratigraphical evidence of a possibly contemporaneous early ice advance from the NW across the southern shore of the Moray Firth, such as at Teindland, Boyne Quarry and Gardenstown (Peacock \& Merritt 1997, 2000; Merritt et al. 2003) (Fig. 21).

5.2.2. Stage 2. SE flow of ice from the Moray Firth laid down dark grey, shelly diamictons with a rich Jurassic to early Cretaceous palynoflora (Whitehills Glacigenic Formation) (Peacock 2000a), for example, at Boyne Quarry (Gordon 1993f; Peacock \& Merritt 2000) (Fig. 24 \& 25). The ice penetrated inland across central and eastern Buchan towards Aberdeen on at least one occasion (Synge 1963) (Fig. 21), laying down large masses of crushed, dark grey Mesozoic mudstone at Gardenstown (Castle Hill) (Sutherland 1993d; Peacock \& Merritt 1997), Oldmill (Merritt \& Connell 2000a), Ardglassie (Merritt \& Connell 2000b) and at Kirkhill and Leys (Corse Diamicton Member) (Table 10). Ice was apparently sufficiently thick to create SE-orientated striae on the NE flank of the iconic mountain of Bennachie, at c. $335 \mathrm{~m}$ OD (Merritt et al. 2017a) (Fig. 21). Amino acid racemisation (AAR) ratios (Miller et al. 1987) on derived shell fragments in glacigenic sediments, mostly from the King Edward site (Hall \& Peacock 2000) (Fig. 21), indicate that the BIIS last advanced across Buchan in the latter part of the Middle Devensian (Peacock \& Merritt 2000). A substantial shelf-edge parallel ice sheet is speculated to have become established during this stage (Merritt et al. 2017a) (Fig. 23.2).

5.2.3. Stage 3. Till provenance and the direct superimposition of tills suggest that ice flow swung around to the E or ENE along the coast of the Moray Firth, laying down, for example, the Tofthead Till at Teindland (Table 9) (Hall et al. 1995a, 2018), the Old Hythie Till Formation at Boyne Quarry (Peacock \& Merritt 2000) (Fig. 24), the Byth Till Formation at the Howe of Byth (Hall et al. 1995b) (Fig. 22) and the Hythie Till Formation at Oldmill and Kirkhill (Merritt et al. 2003) (Table 10) (Fig. 23.3). A major glacial reorganisation appears to have occurred associated with thinning of the ice sheet, but apparently not resulting in widespread glacial retreat across the region. 
5.2.4. Stage 4. Sparse, poorly developed, streamlined subglacial landforms in western Buchan (Fig. 26, flow-set 33) indicate possible NNW drawdown of ice towards the Moray Firth basin from an ice divide stretching from the Cairngorms towards Buchan (Hughes et al. 2014), but no contemporary till unit has been reported (Merritt et al. 2017a). This scenario is supported by crossing striae recorded at two localities SSE of Banff (Fig. 21), where eastward-directed striae are cut by N or NNE-directed ones (Read 1923; Merritt et al. 2003), but there is little evidence in eastern Buchan for northward flow, possibly because that area was protected beneath cold-based ice.

5.2.5. Stage 5. Ice flowing through the Moray Firth basin and Strathmore appears to have subsequently thickened, coalescing at the 'Angle of Buchan', between Fraserburgh and Peterhead, as reconstructed by Clapperton \& Sugden (1977) (Fig. 23.4). As the inland boundary of the Hatton Till Formation (Fig. 3B), laid down by Strathmore ice, can be traced from the Ythan valley NE across ground above $80 \mathrm{~m}$ OD (grey dashed line on Fig. 26a), there was probably ice occupying the central North Sea basin, preventing ice from flowing directly offshore from Strathmore. Absence of evidence suggests that Central Buchan was mostly protected from glacial erosion beneath cold-based ice at this time. A small ice-free enclave appears to have opened up soon after in eastern Buchan, at the confluence of Strathmore, East Grampian and Moray Firth-sourced ice, where deltaic deposits formed in Glacial Lake Ugie at its 80 m OD level (Merritt et al. 2003, 2017a) (Fig. 26a).

5.2.6. Stage 6. East Grampian ice slowly retreated W across Buchan (Fig. 26a), leaving a reticulate network of glacial drainage channels of a type associated with cold-based ice margins (cf. Benn \& Evans 2010, fig. 8.38) and laying down the Banchory Till Formation (Fig. 3B). A local glacial reorganisation followed that involved a further advance of Strathmore ice onshore between Aberdeen and Peterhead, up the valley of the River Ythan to the vicinity of Ellon, where laminated silts and clays occur that formed in a proglacial, ice-dammed lake (Merritt et al. 2003) and formed arcuate end-moraines at the Cross-Stone site nearby (Gemmell et al. 2007) (Fig. 26a). The ice also advanced into the lower Ugie valley during this event, named as the 'Logie-Buchan Readvance' by Merritt et al. (2017a). It dammed Glacial Lake Ugie at its $50 \mathrm{~m}$ OD level (Fig. 26b), in which thick sequences of laminated muds were deposited (Ugie Clay Formation) (Peacock \& Connell 2000). Glaciofluvial deposits associated with both the former lakes experienced intense periglacial conditions during subsequent stages, testified by widespread preservation of tundra polygons and other cryogenic phenomena in the Ugie Valley (Gemmell \& Ralston 1984), but attempts at OSL dating the glaciofluvial sediments proved inconclusive (Gemmell et al. 2007).

The ice lobe occupying Logie-Buchan subsequently decayed to form fresh, hummocky topography typical of ice stagnation (Jamieson 1882). The associated deposits of the LogieBuchan Glacigenic Subgroup are generally undivided as they comprise a complex interbedded sequence of clayey diamict, sand, silt, clay and gravel, typically vivid reddish brown in colour. Sands and gravels forming eskers and kame-terraces are assigned to the Kippet Hills Sand and Gravel Formation, which contains a distinctive suite of glacial erratics, in particular Permian limestone, and shells derived from the floor of the North Sea basin immediately to the east (Gordon 1993g; Hall \& Jarvis 1995; Merritt et al. 2003) (Fig. 26). Although East Grampian ice had retreated from at least the lower reaches of the Ythan and 
Ugie valleys during the Logie-Buchan Readvance (Fig. 26b), the two ice masses abutted in the vicinity of Aberdeen where there is both stratigraphical and geomorphological evidence at Nigg Bay (Fig. 21) for limited eastward readvance ('Aberdeen Readvance') (Merritt et al. 2003), but no confining dates.

5.2.7. Stage 7. Strathmore and East Grampian ice continued to 'unzip' down the E coast, associated with widespread glaciofluvial and deltaic deposition around Aberdeen (Lochton Sand and Gravel Formation and Glen Dye Silts Formation) (Simpson 1948, 1955; Merritt et al. 2003) (Fig. 26b). A marine incursion led to the deposition of red clays of the Tullos Clay Member (Errol Formation) when relative sea level (RSL) stood at about $30 \mathrm{~m}$ OD (Peacock 1999). The 'unzipping' continued down the coast to Montrose, where red marine clay of the Lunan Bay Clay Member was laid down at Lunan Bay (Fig. 23.5). McCabe et al. (2007a) conclude that the clay accumulated in open waters following a minor readvance at 20.1 $20.9 \mathrm{cal}{ }^{14} \mathrm{C}$ ka BP, when RSL stood at about $22 \mathrm{~m} \mathrm{OD}$. However, the basis of these authors' investigation has been questioned by Peacock et al. (2007) and Sejrup et al. (2009), who comment on how the dates are incompatible with youngest ages of c. 17.5 ka for deglaciation of ground above $200 \mathrm{~m}$ on Mormond Hill (Fig. 26b) and Pitfichie, SSW of Inverurie (Fig. 21), provided by cosmogenic techniques (Phillips et al. 2008). Furthermore, in a review of relative sea-level changes, glacial isostatic modelling and ice sheet reconstructions from the British Isles since the LGM, Shennan et al. (2006) conclude that the area only became ice-free after c.17 ka (Smith et al. 2018).

5.2.8. Stage 8. This stage is correlated with the Fladen 1 Readvance $\left(17.5 \mathrm{cal}{ }^{14} \mathrm{C} \mathrm{ka} \mathrm{BP}\right)$ during which ice advanced SE into the Witch Ground basin of the North Sea (Sejrup et al. 2015), but the contemporaneous position of ice in NE Scotland is unclear (Clark et al. 2012; Sejrup et al. 2015). The Scottish and Scandinavian ice sheets had separated by this time as the Viking Bank (E of Shetland) had become ice-free by c. 18.3 ka (Peacock 1995; Hughes et al. 2016; Stewart et al. 2019) (Fig. 23.6).

5.2.9. Stage 9. The mapped extent and provenance of the Essie Till Formation (Fig. 3B) combined with evidence from striae around Peterhead and Fraserburgh suggests that a limited readvance of Moray Firth ice occurred prior to its subsequent retreat across the NE tip of Buchan (Peacock 2000b). By this stage a huge ice lobe would have occupied most of the Moray Firth basin (Clark et al. 2012). It was fed from the NW through to the SE, delimited by sea-bed features that can be traced from Peterhead to the $\mathrm{N}$ tip of Shetland via the Bosies Bank, in the outer Moray Firth (Clark et al. 2012) (Fig. 23.6). The Bosies Bank has been interpreted as a push moraine (Graham et al. 2010, 2011) now judged to have formed during the Fladen 2 Readvance at $16.2 \mathrm{cal}{ }^{14} \mathrm{C}$ ka BP (Sejrup et al. 2015).

5.2.10. Stage 10. Evidence from the raised glaciomarine deposits of the St Fergus Silt Formation suggests that the southern margin of the Moray Firth ice lobe terminated in the sea in the vicinity of St Fergus, at a RSL of c. $12 \mathrm{~m} \mathrm{OD}$, before a minor onshore readvance created the St Fergus Push Moraine (Hall \& Jarvis 1989; Merritt et al. 2003) (Fig. 26c). This feature includes faulted, tilted and deformed masses of bedded marine silt and sand formed by ice push from the E or NE. The absence of contemporary late-glacial marine deposits south of Peterhead (Shennan et al. 2006; Smith et al. 2018) suggests that the sea had retreated from the area owing to rapid glacio-isostatic rebound (Merritt et al. 2003). 
Radiocarbon dates on marine bivalves in the deformed silts suggest that the readvance occurred sometime after $17.5 \mathrm{cal}{ }^{14} \mathrm{C}$ ka BP (Hall \& Jarvis 1989; Peacock 1999). The push moraine has been linked tentatively with sea-bed features off the northern tip of Orkney (Clark et al. 2012) (Fig. 23.6) and it possibly correlates with a minor readvance that deposited the Wick Till in Caithness (Hall \& Riding 2016) (Section 3.2).

5.2.11. Stage 11. During subsequent retreat the southern margin of the Moray Firth ice lobe was pinned along the Banffshire coast where the lacustrine Kirk Burn Silt Formation accumulated in proglacial lakes, and swathes of glaciofluvial outwash (Blackhills Sand and Gravel Formation) were laid down in association with ice-marginal drainage channels (Merritt et al. 2003) (Fig. 26c). Evidence of minor readvances of the Moray Firth ice lobe against the coast have been reported, notably to the $W$ of Banff (Merritt et al. 2003). A limit based on sea-bed ridges that swing around from the vicinity of Banff to the NE tip of Caithness has been identified by Clark et al. (2012) (Fig. 23.6). Merritt et al. (2017a) tentatively link this stage with deposition of the so-called 'Northern Drift', which resulted from a northward advance of ice towards the Moray Firth basin (Read 1923; Bremner 1934, 1943). It laid down little till, for example at Boyne Quarry (Fig. 24), but left eskers, retreat moraines and numerous blocks of locally derived Huntly/Knock Gabbro (Read 1923; Peacock and Merritt 2000) (Fig. 25a).

A significant change in the character of the landscape occurs inland at retreat limits formed by moraine ridges $S$ of Bennachie (Blairdaff Moraine Formation) and around Durn Hill (Merritt et al. 2003, 2017a) (Fig. 25a). For example, periglacial phenomena, specifically ice-wedge pseudomorphs and sheets of gelifractate and gelifluctate are widespread to the NE, across central Buchan (Synge 1956; Romans et al. 1966; Connell \& Hall 1987), where a reticulate network of ice-marginal drainage channels formed at the retreating ice sheet margin (Clapperton \& Sugden 1977). The channels are typically incised into bedrock with little or no associated till (Merritt et al. 2003), they are rarely associated with eskers or other ice-contact glaciofluvial deposits (Merritt et al. 2003) and they have a style that is typical of those formed at cold-based ice margins (cf. Benn \& Evans 2010, fig. 8.38). In contrast, relatively fresh-looking moraine ridges and glaciofluvial deposits relatively devoid of periglacial phenomena are more common to the SW, at least on lower ground (Sutherland \& Gordon 1993d).

It is suggested that the fresher topography formed after a significant regional re-expansion of ice associated with the 'Northern Drift', following prolonged very cold conditions, but the event is currently undated. At the Howe of Byth site (Hall et al. 1995b) (Fig. 22) the Auchmedden Gravel Formation forms an upper fan that was fed from water flowing eastwards via interconnected glacial drainage channels typical of those associated with westward retreating ice across central Buchan (Merritt \& Peacock 2000) (Fig. 25b). Gemmell et al. (2007) obtained an OSL luminescence age estimate of c. 61 ka from the gravel unit, but it is older than the luminescence ages of c. 45 and 38 ka obtained from the Howe of Byth Gravel below (Duller et al. 1995).

5.2.12. Stage 12. Peacock et al. (1968) present geomorphological evidence suggesting that ice re-occupied the lower reaches of Strathspey during a significant, but poorly constrained readvance that they named as the Elgin Oscillation (Fig. 23.6). The Waterworks Till was 
probably laid down during this event at Teindland (Table 9) (Hall et al. 1995a). Ice at the coast ponded lakes (Glacial Lake Rothes) in an area previously vacated by East Grampian ice (Bremner 1934), such as at Tofthead, upstream of Fochabers (Connell 2000). The direction of large-scale foreset beds in deltaic deposits preserved in Glen Rothes, S of Elgin, and Glen Rinnes, SW of Dufftown, indicate that meltwater entered the lakes from the $\mathrm{N}$ and $\mathrm{S}$, respectively (Merritt et al. 2003). Sets of N-S orientated linear transverse ridges around Elgin (Peacock et al. 1968) subsequently formed at the westward retreating margin of Moray Firth ice (Merritt et al. 2017d). As similar features have not been recorded to the $E$ of the Spey, their presence within the glacial limits of the Elgin Oscillation suggests that glaciological conditions may have changed following that event (still not firmly dated), associated with the initiation of the Moray Firth Ice Stream (Hughes et al. 2014).

\subsection{Southern Argyll and Arran}

Southern Argyll, including Kintyre, Islay and Arran (Fig. 27), contains evidence of glaciation that provides an important link between the terrestrial geomorphological and lithostratigraphical records of SW Scotland and NE Ireland (Finlayson et al. 2014) (Table 12). It also links the sedimentary records of the fjord-like coastal terrain of the western Scottish Highlands with the Malin Shelf beneath the Atlantic Ocean to the W (Fig. 27). This is another region that is notable for the presence of shell-bearing clays underlying till, particularly at sites in, and around Tangy Glen, on the western coast of Kintyre (Fig. 27A), at elevations of between 40 to $60 \mathrm{~m}$ OD (Sutherland 1993f). Deposits containing both cold and temperate marine molluscs, ostracods and foraminiferids also occur on the southern tip of Arran, at up to $55 \mathrm{~m}$ OD (Sutherland 1981). As at Afton Lodge (Merritt et al. 2014), in Ayrshire, the shelly deposits have either been interpreted to be in situ (Sutherland 1981) or attributed to glacial rafting (Synge \& Stephens 1966) (section 5.4.2). In either case, erratic dispersal patterns and glacial striae suggest that the localities on Kintyre were subsequently over-ridden by ice flowing $W$ towards the Malin Shelf (Finlayson et al. 2014). However, ice-marginal features on the $W$ coast of Kintyre, together with striae on Arran, suggest that the final flow was towards the S through the Kilbrannan Sound and the Outer Firth of Clyde (Fig. 27G), consistent with the occurrence of red tills derived from Permo-Triassic rocks along the $\mathrm{W}$ coast of Kintyre (Synge \& Stephens 1966). Two suites of recessional moraines have been recognised in the mountains of Arran (Gemmell 1973), an inner suite attributable to the Loch Lomond (Younger Dryas) Stadial, and more subdued outer limits formed earlier during deglaciation (Ballantyne 2007). The relationship between the outer moraines and raised deltaic deposits in Glen Dougarie, western Arran, indicate that they formed after RSL had fallen from $32 \mathrm{~m}$ OD (Finlayson et al. 2014).

A raised rock platform attributed to an interglacial period pre-dating the last glacial cycle passes beneath till in the vicinity of Tangy Glen, one of several such occurrences along the W coast of Scotland (Gray 1993; Smith et al. 2018). Finlayson et al. (2014, fig. 5B) note that at Drumore Burn, S of Glenacardoch Point (Fig. 27G), $15 \mathrm{~m}$ of till overlay up to $8 \mathrm{~m}$ of cobble-gravel with weakly developed herring-bone cross stratification. Tentatively interpreted as beach gravel, the un-named unit overlies a rock platform at c.18 $\mathrm{m}$ OD, only a few metres higher than the one described by Gray (1993) at Glenacardoch Point.

In western Islay up to $60 \mathrm{~m}$ of pink clays, silts and diamicton rest on raised shore platforms (Benn \& Dawson 1987). Luminescence dates of 55-40 ka for these supposed 
glaciomarine sediments suggest an Early Devensian age (Dawson et al. 1997), but the dates may be in error due to inadequate exposure to light in turbid water (Peacock 2008).

Furthermore, the terraced surface of the sequence at up to $80-90 \mathrm{~m}$ above OD is far above the Late Devensian marine limit in western Islay at 23 m OD (Dawson 1982). Considering that global sea level was possibly as low as $-75 \mathrm{~m}$ and never significantly higher than $-50 \mathrm{~m}$ in the Early Devensian (Shackleton 1987), considerable glacio-isostatic depression would be required immediately following the retreat of a thick Early Devensian ice sheet for the sequence to have been deposited in situ (Sutherland 1981). Whilst a similar explanation has been proposed to account for the occurrence of other 'high level' cold-water marine/glaciomarine sediments around Scotland (Sutherland 1981), all other occurrences are now considered more likely to have been emplaced by glacial rafting during the last glaciation (Merritt 1992; Peacock 2008; Finlayson et al. 2014; Merritt et al. 2014).

Although no formal lithostratigraphy has been established, the glacial history of the region has become much clearer following recent analysis of NEXTMap imagery combined with cosmogenic dating and fieldwork. For example, Finlayson et al. (2014) have elucidated seven stages (summarised below) combining their findings with ice-sheet reconstructions made for west central Scotland (Finlayson et al. 2010), SW Scotland (Salt \& Evans 2004), northern England (Livingstone et al. 2012), NE Ireland (Greenwood \& Clark 2009; McCabe \& Williams 2012) and the Malin Shelf (Dunlop et al. 2010) (Fig. 27) (Table 12).

Evidence from erratics reveals that ice advance was initially directed through $\mathrm{N}$-S aligned, geologically-controlled basins that have been carved through successive glacial cycles. Ice entered these basins in stage 1 from a restricted, marine-proximal mountain ice sheet similar to those that probably existed during many cold stages of the middle and late Pleistocene during 'average' conditions (Porter 1989) (Fig. 27A). The ice front advanced against reverse slopes along the western coast of Kintyre, leading to the local preservation in hollows of glacial rafts of shelly sediment. The Western Highlands ice sheet subsequently joined with a smaller ice cap centred over the Southern Uplands during stage 2, which witnessed a major glacier expansion. An E-W ice divide developed over northern Kintyre, Arran and the Firth of Clyde, protecting the underlying landscape from glacial erosion. The ice sheet became sufficiently thick for ice to flow directly westwards to the Malin Shelf, and was no longer topographically constrained, creating WNW-directed bedforms (streamlined hills, crag-and-tail forms and drumlins) across southern Kintyre, maintaining the same alignment at all elevations. Following a possible early advance of Scottish ice into Belfast Lough, in Northern Ireland (Greenwood \& Clark 2009), an E-W ice ridge developed over the North Channel, bridging the British and Irish ice centres (Fig. 27B).

The N-S ice divide centred over the Firth of Clyde migrated some $60 \mathrm{~km}$ to the $\mathrm{E}$ during stage 3, when enhanced drawdown towards the western marine margins of the BIIS created WNW-orientated streamlined subglacial bedforms across till along the western seaboard of Kintyre (Fig. 27C). Finlayson et al. (2014) infer that a shear margin within the ice sheet across southern Arran and central Kintyre separated warm-based ice, which flowed towards the Malin Shelf, from cold-based ice within a 'sticky spot' that protected the delicate mountaintop tors of northern Arran (cf. Benn \& Evans 2010, p. 472) (Fig. 27B). Ice flowing over southern Arran and Kintyre merged with powerful NW flowing ice to overwhelm Islay (Cousins 2012). Finlayson et al. (2014) conclude that the regional N-S ice divide then 
migrated westwards again, following a substantial, renewed build-up of ice during stage 4. It became pinned over Arran and the eastern seaboard of Kintyre causing minimal subglacial erosion there (Fig. 27D). An ice divide over the North Channel linked Antrim and the Southern Uplands at this time, which is possibly contemporaneous with the Gosforth/Blackhall Wood Oscillation (Scottish Readvance) into the northern Irish Sea basin (Merritt \& Auton 2000; Livingstone et al. 2012; Chiverrell et al. 2018) and the Clogher Head Readvance of Irish ice in NE Ireland (McCabe et al. 2007b; J. Clark et al. 2012; Merritt et al. 2018) (Fig. 27E) (section 5.5).

During stage 5, ice flowing SW towards the North Channel subsequently formed streamlined, topographically unconstrained subglacial bedforms with this general alignment across thick till mantling western Kintyre (Finlayson et al. 2014) (Fig. 27F). Similar SSWorientated bedforms in southern Arran indicate probable contemporaneous funnelling of ice out of the Outer Firth of Clyde, which must have followed breaching of the eastern half of the North Channel ice divide that previously linked Antrim and the Southern Uplands (Fig. 27E). The absence of streamlined landforms on the high ground of southern Kintyre and northern Arran, together with the local preservation of the mountaintop tors, suggest that either cold-based ice protected these areas from subglacial erosion or they formed nunataks. This likely resulted from the migration of the North Channel ice divide across these areas, linking Kintyre and Antrim.

Following rapid wasting of the Irish Ice Sheet, ice flowing from the more substantial ice centre positioned over the western Scottish Highlands temporarily advanced into Northern Ireland during the 'East Antrim Coastal Readvance' (McCabe \& Williams 2012; Finlayson et al. 2014) (Fig. 27F). Suites of converging subglacial landforms identified by Finlayson et al. (2014) across NW Kintyre, parts of southern Kintyre and southern Arran indicate that ice became increasingly topographically constrained during deglaciation (stage 6). The distribution and orientation of ice marginal meltwater channels mapped by Finlayson et al. (2014) in the region indicate that the major pathways of glacier retreat were through corridors of low-lying ground and glacially over-deepened basins (Fig. 27G).

The pattern of retreat of local glaciers on Arran deduced by Gemmell (1973) has been generally accepted, involving limited advances following separation from the main retreating outlet glaciers occupying the Kilbrannan Sound and Firth of Clyde (stage 7). The sediments and geomorphology in Dougarie Glen, western Arran, together with the results of recent cosmogenic dating there (Ballantyne 2007; Finlayson et al. 2014), suggest that a limited advance of local ice occurred at c. 16.2 ka BP following a fall in RSL from $32 \mathrm{~m}$ OD (Fig. 27H). This timing supports RSL simulations for the area, where a falling RSL is modelled between c. 16.5 and 15 ka BP (Shennan et al. 2006; Smith et al. 2018).

\subsection{West Central Lowlands}

The lithostratigraphy of the region (McMillan et al. 2011a), which includes the Glasgow conurbation and Ayrshire, is based on formations originally proposed by Rose $(1981,1989)$, Browne \& McMillan (1989) and Sutherland (1999) (Fig. 28). The history of glaciation has been disputed (Price 1975; Menzies 1976, 1981; Sutherland \& Gordon 1993e; Rose \& Smith 2008), but recent geomorphological, lithostratigraphical and three-dimensional mapping 
investigations have substantially resolved the glacial history this area (Finlayson 2012; Finlayson et al. 2010, 2014; Kearsey et al. 2018).

5.4.1. Glasgow area (Clyde Basin). At Balglass Burn, north of Glasgow (Fig. 29F), a weathered till containing partially decomposed clasts with weathering rinds underlies organic sands that have been radiocarbon dated to the Middle Devensian $\left(36.0-34.9 \mathrm{cal}{ }^{14} \mathrm{C}\right.$ ka) (Brown et al. 2007). The sands are capped by relatively unweathered till formed during the last glaciation. Balglass is thus one of very few reliably described and sampled localities in Scotland where ice-free conditions can be proven immediately before the last glaciation, at c. $35 \mathrm{cal}{ }^{14} \mathrm{C}$ ka BP (Table 13); others notably include Sourlie (see below) and Tolsta Head, on the Isle of Lewis (Whittington \& Hall 2002; Hall et al. 2018) (section 3.3).

The considerable degree of weathering observed in the lower till at Balglass suggests that it was formed in a pre-Ipswichian (MIS 5e) glaciation (Brown et al. 2007). The unit probably correlates with the Ballieston Till Formation in the Clyde basin, which was laid down by a substantial advance of ice from the NW following a significant period of exposure (Price 1975: Browne \& McMillan 1989; Sutherland \& Gordon, 1993e) (Fig. 29A). The Ballieston Till is shown from site investigations in parts of northern Glasgow to be overlain by gravelly sands of the Cadder Sand Formation (Menzies 1976, 1981; Finlayson 2012; Kearsey et al. 2018), from which bones and teeth of woolly rhinoceros have been obtained at two localities in the vicinity of Bishopbriggs (Fig. 29F) (Hungryside and Wilderness Pit) (Rolfe 1966). Following ultrafiltration pre-treatment a revised radiocarbon age of $31.1{ }^{14} \mathrm{C}$ ka $\mathrm{BP}$ (c. $35 \mathrm{cal}{ }^{14} \mathrm{C}$ ka BP) has been obtained from bones collected from Wilderness Pit (Jacobi et al. 2009). Excavations at the type site of Wilderness Pit (Rose 1989) showed that the Cadder Sand is locally overlain by water-lain diamictons of the Broomhill Clay Formation. Borehole records reveal that the latter comprises up to $15 \mathrm{~m}$ of very compact, laminated, glaciolacustrine mud with dropstones (Browne \& McMillan 1989; Finlayson 2012). These glaciolacustrine muds, if varved, indicate that ponding occurred for at least 1000 years during the earliest stages of the last glaciation (Fig. 29A) and their elevation suggests that contemporary sea level was at least $25 \mathrm{~m}$ below present sea level (Browne \& McMillan 1989). The Broomhill Clay, Cadder Sand and Ballieston Till are mainly located within concealed bedrock depressions, particularly a $108 \mathrm{~m}$ deep, $1500 \mathrm{~m}$ wide and $26 \mathrm{~km}$ long elongate depression, probably a tunnel valley (cf. Kehew et al. 2012), that trends WSW-ENE beneath the floodplain of the River Kelvin (Kearsey et al. 2018) (Fig. 29F).

The Broomhill Clay and/or Cadder Sand are generally overlain by the widespread Wilderness Till Formation (Fig. 3B) assigned to the last glaciation (Rose et al. 1988; Rose 1989; Sutherland \& Gordon 1993e; Forsyth et al. 1996; Hall et al. 1998). At Wilderness Pit the Sand is sheared, folded and includes seams of diamicton, possibly glacitectonite, and the overlying Wilderness Till includes tectonic slices and rafts of sand and laminated clay from underlying units (A.M. Hall unpublished). In eastern Glasgow the Wilderness Till is overlain by the Broomhouse Sand and Gravel Formation, which forms ice-contact topography including eskers, mounds, flat-topped kames and kettleholes (Browne \& McMillan 1989; Rose \& Smith 2008; Finlayson 2012; Kearsey et al. 2018). The formation may be subdivided locally into the Ross Sand Member (deltaic sand and gravel) and the Bellshill Clay Member (glaciolacustrine laminated clay) (Browne \& McMillan 1989). These units were deposited in 
ice-dammed 'Glacial Lake Clydesdale' (Bell 1871; Sissons 1967a, b) after the ice sheet margin had retreated NW (Sutherland \& Gordon 1993e) (Fig. 29E).

Late-glacial raised glaciomarine deposits assigned to two members of the Clyde Clay Formation (Fig. 28) were laid down around the Clyde estuary downstream of Glasgow following deglaciation at c. 15 ka BP (Peacock 1971, 2003; Rose 2003; McMillan et al. 2011a) (Fig. 30). The Paisley Clay Member, which typically comprises thinly laminated mud with dropstones and includes the cold-water foraminifera Elphidium clavatum, occurs up to altitudes of c. 40 m OD (Browne \& McMillan 1989). The Linwood Clay Member is confined to western areas of the estuary where it commonly overlies the Paisley Clay. It consists of more thickly bedded mud with a richer, warmer-water faunal assemblage (Peacock 2003).

5.4.2. Ayrshire. The sequence in Ayrshire (Fig. 28) is largely based on sections in a former opencast coal pit at Sourlie, near Irvine (Jardine et al. 1988; Sutherland \& Gordon 1993e; Sutherland 1999; Bos et al. 2004; Finlayson et al. 2010), and on natural river bank sections at Afton Lodge, near Ayr (Merritt et al. 2014) (Fig. 30). Both sites lie within a suite of ribbed moraine (Fig. 30). The importance of the Sourlie site lay in the discovery of thin lenses of organic material occurring between two units of till (Jardine et al. 1988). These lenses, now assigned to the Sourlie Organic Silt Formation (McMillan et al. 2011a), occupy shallow depressions within the surface of the underlying glaciofluvial Armsheugh Sand and Gravel Formation. They have yielded a very rich flora and fauna deposited within a shallow pond in a treeless, low-shrub to sedge-moss tundra environment, together with bones of woolly rhinoceros and antler fragments of reindeer. Radiocarbon dates on the antler, plant debris and bulk organic matter range between 33.5 and $29.0 \mathrm{cal}{ }^{14} \mathrm{C}$ ka BP, confirming a Middle Devensian age (Bos et al. 2004). The basal unit at Sourlie (Littlestone Till Formation) comprises dark grey stony diamicton locally enclosing deformed sheets of sand. The till is overlain by up to $3.5 \mathrm{~m}$ of clay-rich gravel of uncertain origin named as the Lawthorn Diamicton Member. The two units were assumed to have been deposited during an Early Devensian glaciation by Sutherland (1999), but they could be older.

At Sourlie, the Wilderness Till has been divided into two members (Fig. 28). The Eglinton Shelly Till is a diamicton containing fragments of marine shells together with far-travelled sedimentary, igneous and metamorphic rocks from the Scottish Highlands. It represents the 'shelly tills' of the region (Sutherland \& Gordon 1993e), and some Arctica islandica shell fragments have yielded Late Devensian amino acid ratios (Jardine et al. 1988). The overlying Auchenwinsey Till is a grey diamict containing local Middle Coal Measures and basic igneous rock lithologies (Jardine et al. 1988).

The Eglinton Shelly Till at Afton Lodge is associated with several large bodies of shelly clay (see Gordon 1993k and references therein), which have been assigned to the Afton Lodge Clay Formation by Merritt et al. (2014). They comprise weakly laminated to massive, stiff, calcareous mud containing sparse shells, foraminiferids, ostracods, fish debris and echinoid spines. The generally well-dispersed pebbles include Carboniferous sandstone, coal and basalt together with more far-travelled crystalline 'Highland' rock types. The shelly clay contains abundant marine macro- and micro-fauna, as well as palynomorphs consistent with its deposition within a shallow marine to estuarine environment. Faunal changes within the 
main body of marine clay record at least one millennial-scale cycle of Arctic-boreal, to boreal, and back to Arctic-boreal climatic conditions (Merritt et al. 2014). A radiocarbon date of $>41{ }^{14} \mathrm{C}$ ka BP obtained from the foraminifera indicates that these marine clays are older than the surrounding till (Merritt et al. 2014).

The location of Afton Lodge suggests that the rafts were transported at least $10 \mathrm{~km}$ from their likely source within the Firth of Clyde basin, prior to being accreted at between 70 and $82 \mathrm{~m}$ OD (Merritt et al. 2014). The rafts of shelly clay, together with closely associated bodies of 'shelly till', which were possibly formed mainly by the attenuation and crushing of other rafts during their transport within the subglacial deforming bed (cf. Aber 1985), were emplaced during an early phase of the LGM glaciation of Scotland by ice flowing from the western Grampian Highlands of Scotland. This ice flowed through the topographically confined Firth of Clyde basin where it probably detached the blocks of unfrozen marine sediment prior to splaying-out onshore against reversed slopes, leading to subsequent raft emplacement and creation of closely associated ribbed moraine (Merritt et al. 2014). The transport of the rafts was probably facilitated by the development of water-lubricated décollement surfaces along their margins (cf. Phillips \& Merritt 2008).

5.4.3. Regional interpretation. The published literature (Sissons 1967a; Price 1983; Rose \& Letzer 1977: Sutherland 1984; Sutherland \& Gordon 1993e; Rose \& Smith 2008; Finlayson 2012; Finlayson et al. 2010, 2014), together with the numerical ice sheet model of Hubbard et al. (2009), indicate that ice initially advanced into the area from the NW (Fig. 27A, 29A). The ice front generally advanced against reverse slopes leading to the widespread formation of ribbed moraine perpendicular to flow (Hughes et al. 2010; Finlayson et al. 2010) (Fig. 30). That landforms from such an early stage of glaciation could survive is supported by preservation of Middle Devensian deposits, such as at Sourlie and Bishopbriggs. Merritt et al. (2014) conclude that the rafts of Afton Lodge Clay were detached and entrained into the deforming layer beneath the ice at this stage as it advanced from the Firth of Clyde basin SE towards Nith Bridge, near New Cumnock (Sutherland 1993g) (Fig. 30), and S to Stranraer, the most southerly-known occurrence of shelly diamicton in Scotland (Phillips et al. 2009; Peacock \& Everest 2016). The advance of ice into the Clyde basin resulted in ponding (Price 1975 ) and the ribbed moraine may have been initiated locally as ice-marginal sediment ridges generated by folding and thrusting (McMillan \& Browne 1983; Finlayson 2012).

Sustained stadial conditions at the LLGM (30-25 cal ka BP) resulted in the development of an ice divide over the Firth of Clyde basin, beneath which there was minimal subglacial erosion and landscape modification. Once ice had become sufficiently thick to overtop the main Clyde-Forth drainage divide, a wide corridor of fast-flowing ice flowed $\mathrm{E}$ towards the Firth of Forth forming drumlins (Rose 1987; Rose \& Smith 2008; Finlayson 2012), striae (Paterson et al. 1998) and a train of essexite erratics that were dispersed from their source near Lennoxtown at the foot of the Campsie Fells N of Glasgow (Peach 1909; Shakesby 1978) (Fig. 27B, 29B). A significant dispersal centre had developed over the Southern Uplands by this stage, contributing to deflection of ice in the Clyde basin towards the NE. This flow formed streamlined bedforms and deposited till of Southern Uplands provenance on shelly diamictons (Eglington Shelly Till) at Nith Bridge (Holden \& Jardine 1980; Sutherland 1993e) (Fig. 30). 
A broad belt of streamlined bedforms in rock, striae and drumlins carved into the earlierformed ribbed moraine indicate convergent flow into the outer Firth of Clyde basin (Rose \& Letzer 1977; Finlayson 2012: Finlayson et al. 2014) (Fig. 27C). This phase clearly followed a major change in the ice sheet configuration that probably resulted from enhanced marine drawdown to the $\mathrm{W}$, initiating an eastward migration and substantial lowering of the ice divide (Fig. 27C, 29C). This glacial reorganisation probably eventually reduced the power of eastward flow towards the Firth of Forth and resulted in the relatively early deglaciation of eastern Scotland (Sissons 1967a, b; Sutherland 1984). An intermediate phase probably occurred when ice covering the Southern Uplands was scavenged and drawn down to the west around the south of Arran, as indicated by the westward transportation of microgranite erratics derived from the island of Ailsa Craig, off the SW Scottish coast (Sissons 1967a) (Fig. 27C).

Following substantial thinning and local deglaciation, a subsequent change in ice sheet configuration is indicated in the $E$ of the region by a suite of landforms including local easttrending subglacial bedforms, eastward-descending ice-marginal meltwater channels and suites of ice-contact glaciofluvial landforms (including the Chapelton Moraine Belt) (Finlayson et al. 2010; Finlayson 2012; Clark et al. 2012) (Fig. 30). Collectively, they demonstrate ice-divide migration back towards the $\mathrm{W}$, coupled with probable thickening of ice located over the Firth of Clyde basin (Finlayson 2012; Finlayson et al. 2014) (Fig. 27D). The Highland and Southern Uplands ice-caps subsequently separated across southern parts of the Clyde Basin in the vicinity of the Carstairs Eskers (Finlayson 2012) (Fig. 29D), supporting the conclusion of Thomas \& Montague (1997) and Huddart \& Bennett (1997) that this well-documented esker system (Gordon 1993I), and others nearby (Bennett et al. 2007), developed in an interlobate sediment sink during uncoupling of northern- and southern-sourced ice caps. The configuration is roughly that proposed for the supposed 'Perth Readvance' in central Scotland (Sissons 1963, 1964, 1967a, b), when the upper catchment of the River Clyde drained eastwards into that of the River Tweed (Shaw \& Merritt 1982). A minor readvance of Southern Uplands ice is apparent in the Ayr valley near Greenock Mains (Fig. 30) where the orientation of a nested assemblage of meltwater channels and moraine ridges indicates a late NE advance (Holden \& Jardine 1980). Icemarginal ponding first began on the watershed between the catchments of the NE-flowing Avon Water and the W-flowing River Irvine, in Glengavel (Fig. 29D \& 30), where thick sequences of laminated glaciolacustrine silt coarsen upwards into deltaic sand and gravel occur up to an elevation of at least 205 m OD (Nickless et al. 1978).

A phase of more active and widespread streamlining towards the $E$ and SE accompanied the final phase of ice-sheet thinning in the region (Fig. 29E). One or more significant icefront oscillations occurred late during deglaciation. The streamlined bedforms assigned to this phase terminate abruptly in the vicinity of the Kilmarnock and Blantyreferme moraine complexes (Fig. 30), to the $E$ of which suites of glaciolacustrine and deltaic sediments were laid down in the Clyde and Irvine valleys (Fig. 29E). Water previously ponded only within upper parts of the Avon Valley eventually merged with a much larger lake, 'Glacial Lake Clydesdale' (Bell 1871), which occupied the Clyde valley and its tributaries upstream of Glasgow (Fig. 29E). Paterson et al. (1998) deduced that the level of Lake Clydesdale dropped in stages as the NW retreat of the ice margin in the lower Clyde Valley made available spillways to the $E$ at progressively lower elevations of 200, 165, 102, and 85 m OD, 
respectively. The lake finally drained $\mathrm{E}$ via a col in the upper Kelvin valley, NE of Glasgow, at about $45 \mathrm{~m}$ OD (Forsyth et al. 1996; Hall et al. 1998).

Lake Clydesdale probably existed during the creation of the 'Main Perth Shoreline' in the Forth estuary (Sissons \& Smith 1965; Sutherland 1984), and possibly into the beginning of the Lateglacial Interstadial (GI-1) (Peacock 1999, 2003). The timing, contemporary sea level and manner in which the late-glacial sea eventually invaded Lake Clydesdale is disputed (see Peacock 2003 for review), but it is generally accepted that the transgression had occurred by $13.1-12.5{ }^{14} \mathrm{C}$ ka BP (based on uncorrected, reported ages from marine shells) (Peacock 1971, 2003; Browne et al. 1977; Peacock et al. 1977; Rose 2003). Eventual disintegration of ice blocking the Clyde estuary resulted in the level of Lake Clydesdale falling from $45 \mathrm{~m}$ to no less than $40 \mathrm{~m}$, the contemporaneous sea level (Peacock 2003). Later stages in the deglaciation to the W of Glasgow have been deduced by Finlayson et al. (2014) (Section 5.3).

\subsection{Solway Lowlands}

A review of the complex lithostratigraphical and geomorphological record of the last glaciation within the Solway Lowlands and surrounding areas has been given by Livingstone et al. (2012), who identify seven distinct sets of glacially streamlined features relating to six stages of glaciation (Fig. 31). The oldest known unit on the Scottish side of the border is the Chapelknowe Till Formation (McMillan et al. 2011b) (Table 14), which was possibly laid down during an 'Early Advance' of Scottish ice across the Solway Firth, up the Vale of Eden and through the Stainmore Gap into eastern England (Trotter 1929; Hollingworth 1931; Trotter \& Hollingworth 1932b; Evans et al. 2005; Stone et al. 2010; Mitchell 2013; Ballantyne and Small 2018) (Fig. 31A). The till contains a suite of Southern Uplands erratics, including Criffel and Dalbeattie granite and greywacke. The Chapelknowe Till is overlain locally by the 'Middle Sands' of a 'tripartite' sequence that occurs around Gretna, pinching out just $\mathrm{E}$ and $\mathrm{S}$ of Carlisle (Trotter \& Hollingworth 1932a). This middle unit is now assigned to the Plumpe Farm Sand and Gravel Formation, which is capped by a thin 'upper' red diamicton, the Plumpe Bridge Till Member of the Gretna Till Formation (McMillan et al. 2011b). The widespread red, sandstone-rich Gretna Till was laid down by ice flowing from the $\mathrm{W}$ as indicated by its composition and the predominant orientation of drumlins across the lowlands $\mathrm{N}$ of the inner Solway Firth (Livingstone et al. 2008; McMillan et al. 2011b) (Fig. 3B). Relatively little ice flowed into the lowlands from the Langholm Hills, to the north, as revealed by the distribution of the greywacke-rich Langholm Till Formation (British Geological Survey 2005, 2006) (Fig. 3B).

The occurrence of red, granite-bearing till (un-named) passing upwards into rubbly, greywacke-rich till in the Langholm Hills indicates that ice overwhelmed the area from the W during an early phase of the last glaciation (Lumsden et al. 1967; McMillan et al. 2011b). NEXTMap imagery of the Langholm Hills reveals that this region of the Southern Uplands has been relatively little modified by glacial erosion because it was a minor ice-dispersal centre and probably overlain by mainly sluggish, cold-based ice (Fig. 31A). A minor, southward readvance of ice from the Langholm Hills occurred following the separation of ice masses during deglaciation (Lumsden et al. 1967), laying down rubbly diamicton of the Mouldy Hills Moraine Formation (British Geological Survey 2006). Although the Gretna and Chapelknowe till formations have not been mapped to the $E$ of the Langholm Hills, sandstone and granite- 
bearing red tills including a suite of glacial erratics sourced in the Galloway Hills have been recorded there, high on the catchment divide (Day 1970). Together with new evidence from NEXTMap and satellite imagery revealing elongate, glacially streamlined landforms arcing NNE towards the divide (Livingstone et al. 2008; McMillan et al. 2011b) (Fig. 31A), this suggests that transfluence of ice may have occurred into the catchment of the Tweed at the LGM.

The Plumpe Bridge Till has been connected with the late-stage 'Scottish Readvance' into the Solway Lowlands (Dixon et al. 1926; Trotter \& Hollingworth 1932a; Huddart 1991; Merritt \& Phillips 2010). Indeed, the thin and laterally discontinuous nature of the till probably results from a short-lived advance across water-saturated sediment adjacent to proglacial lakes dammed up against higher ground to the $E$ of the ice (Phillips et al. 2007) (Fig. 31F). The 'Middle Sands' were considered to have formed proglacially in, and around, 'Glacial Lake Carlisle' following partial deglaciation of the Solway Lowlands (Dixon et al. 1926; Trotter \& Hollingworth 1932a). This interpretation has been confirmed by the identification in the Caldew Valley, SW of Carlisle, of a sequence of laminated mud deposited in a pro-glacial lake (Livingstone et al. 2010a,b) (Fig 31B). These varved sediments (Blackhall Wood Glaciolacustrine Formation), which are also overlain by a reddish brown 'upper till' that includes mixed Scottish, Lake District and local clasts, are now assigned to the Blackhall Wood/Gosforth Oscillation (Livingstone et al. 2010b, c, 2012; Ballantyne \& Small 2018).

Evidence for a subsequent, minor readvance of Scottish ice includes a striated boulder pavement that is intermittently exposed at low tide west of Powfoot (Brookfield et al. 2010; Merritt 2010). The pavement consists of a single layer of interlocking, ice-bevelled boulders composed predominantly of wacke sandstone with some red Triassic sandstone and sparse granodiorite derived from Criffell, some $15 \mathrm{~km}$ to the $\mathrm{W}$. The boulders have smoothed and striated upper surfaces and both the long axes of the boulders and the striations show a consistent WNW-ESE alignment. The simplest explanation is that the pavement formed subglacially beneath wet-based ice that flowed ESE across previously deposited till and glaciofluvial deposits. The presence of granodiorite boulders from Criffell in diamicton locally overlying the pavement, but not below it, is compatible with a late-stage readvance of ice that splayed out into the Solway Firth from valleys to the N.

The age, regional correlations and integrity of the Scottish Readvance have been controversial (Merritt \& Auton 2000; Evans et al. 2005; Livingstone et al. 2012), but many issues have been resolved recently following new geochronological, offshore geophysical and stratigraphical evidence collected from around the northern Irish Sea Basin (Chiverrell et al. 2018). The latter authors constrain the event to 19.2-18.2 ka and demonstrate it to be a significant regional readvance across the Isle of Man and Cumbrian lowlands. It probably correlates with the Gosforth Oscillation that affected the west Cumbrian coast (Trotter et al. 1937; Merritt \& Auton 2000; Livingstone et al. 2012) and the Clogher Head Readvance at the coast of County Down, in Northern Ireland (McCabe et al. 2007a; J. Clark et al. 2012; Merritt et al. 2018). 


\subsection{East Central Lowlands, Tayside, Fife and the Borders}

In the apparent absence of new, comprehensive field studies in eastern Scotland, McMillan et al. (2011a) assigned existing stratigraphic units to their lithostratigraphic framework (Fig. 3B). Given the historical importance of this region (Sutherland 1993i,j), and particularly the Lothians and Borders (Gordon 1993m), it merits detailed re-investigation, for example in the context of recent understanding of ice flow-pattern evolution and palaeo-ice streams (Everest et al. 2005; Golledge \& Stoker 2006; Hughes et al. 2014; Livingstone et al. 2017). For example, the results of mapping in the valley of the Kale Water, $W$ of the Cheviot Hills, revealed that this upland area lay beneath a cold-based, frozen patch to the east of a thermal boundary related to the Tweed ice stream (Mitchell 2008) (Fig. 31). In the past 15 years superficial deposits have been mapped by BGS in the Borders (around Duns and Moffat), central Galloway, Montrose and Crieff, but no descriptive and interpretive accounts have been written.

A digital dataset of over 100,000 boreholes that penetrate the full thickness of Quaternary deposits in the Central Lowlands has been utilised in a recent study of 'buried' valleys and their infills (Kearsey et al. 2018). The study identified 18 buried palaeo-valleys in the region ranging from 4 to $36 \mathrm{~km}$ in length and 24 to $162 \mathrm{~m}$ in depth, some cross cutting one another. The deepest features are orientated WSW-ENE beneath the Kelvin valley, NE of Glasgow (Browne \& McMillan 1989), the Carron valley, farther to the ENE between Falkirk and Grangemouth (Browne et al. 1984; Browne 2011; Cameron et al. 1998), and the Devon valley at the foot of the Ochil Hills, to the E of Stirling (Parthasarathy \& Blyth 1959. These palaeo-valleys all have undulating longitudinal profiles and are interpreted as tunnel valleys (cf. Kehew et al. 2012) formed during the LGM (Kearsey et al. 2018). The shallower features are generally aligned with ice flow during ice sheet retreat.

\section{Advances and setbacks over the past 25 years in understanding the terrestrial stratigraphic record of the last glacial cycle in Scotland}

\subsection{Advances}

Progress in the last 25 years has been facilitated by a number of developments.

1. The application of a systematic approach to lithostratigraphy (Sutherland 1999; McMillan et al. 2011a) has enabled a more rigorous framework for the recognition and correlation of Pleistocene deposits.

2. Advances in dating techniques have improved understanding and timing of events and the development of a rigorous chronostratigraphy. Refinements in radiocarbon dating through the use of accelerator mass spectrometry have enabled the application to smaller samples and reduced the error limits on older material pre-dating the last glaciation (e.g., Bos et al. 2004; Brown et al. 2007; Jacobi et al. 2009). Recognition of natural variations in the atmospheric concentration of radiocarbon through time and the development of calibration methods to a common calendar timescale have greatly enhanced the comparability and interpretation of dates (Reimer et al. 2013). Although there have been limited applications in Scotland, improvements in luminescence dating and amino acid geochronology have helped clarify Ipswichian and Early Devensian chronostratigraphy, particularly in NE Scotland and around Inverness (e.g., Merritt 1992; Duller et al. 1995; Hall et al. 2002). Surface exposure dating using terrestrial cosmogenic 
nuclides has greatly advanced understanding of the timing, sequence and pattern of the last ice sheet glaciation (Ballantyne \& Small 2018 and references therein).

3. The use of satellite imagery and digital surface models derived from remote sensing, and particularly NEXTMap Britain topographic dataset, has progressed geomorphological mapping and morphostratigraphy (Chandler et al. 2018). It has enabled the recognition of multiple sequential ice-flow patterns during the life of the last BIIS indicated by superimposed glacial lineations (e.g., Salt \& Evans 2004; Golledge \& Stoker 2006; Hughes et al. 2014) and has considerably improved knowledge of glaciation during the Younger Dryas (Ballantyne 2018; Bickerdike et al. 2018).

4. 3-D modelling based on borehole data has helped understanding of the architecture of layered sedimentary sequences (e.g., Finlayson 2012; Kearsey et al. 2018). When combined, the use of lithostratigraphy, geomorphological mapping, 3-D modelling and geochronometry has proved a powerful combination in elucidating the dynamics and pattern of decay of the last ice sheet (Finlayson et al. 2010, 2014).

5. The significant progress in mapping and dating offshore landforms and sediments reviewed by Stewart et al. (2019) has provided a more extended lithostratigraphic and chronostratigraphic framework in which to set the incomplete terrestrial record. Icesheet modelling (e.g., Boulton \& Hagdorn 2006; Hubbard et al. 2009; Patton et al. 2016, 2017) has also highlighted the highly dynamic nature of the last ice sheet and provided further context for interpreting the stratigraphic record.

\subsection{Constraints}

Progress has been hampered by a decline in stratigraphic studies, arising from a number of factors.

1. There has been a shift in research away from regional studies of glacial deposits and landforms based around detailed field survey, mapping and logging of sections to more systematic, desk-based, remote sensing studies and analysis of digital topographic imagery. While the latter have produced important new results, particularly at regional and national scales, the two approaches must be complementary.

2. Few new important natural sections have been discovered and then described. This has been compounded by the end of open-cast coal mining, the opening of fewer small gravel pits, and increasingly stringent restrictions being applied to access resulting from more rigorous health-and-safety legislation. Meanwhile, many former sections have been lost to development, infilling, land restoration or natural degradation. There has also been an absence of resources (human and financial) for routine logging of exposures arising from construction and infrastructure projects (e.g., roads, pipelines, power lines, run-of-river hydro schemes and forestry and wind farm access routes) and for re-excavation of former sections that are now degraded. New excavations typically involve 'cut and cover', so that exposures are largely temporary.

\subsection{Next steps}

Significant advances have been made in elucidating the pattern and timing of deglaciation, but these results have yet to be integrated into numerical ice sheet models in order to test how closely computer simulations match litho- and morph-stratigraphic records. Successful tests would give confidence that model design replicated ice sheet behaviour and so offer the promise of using improved models as frameworks in which to piece together the much more fragmentary records of events during and before the LGM. 
Despite the huge step forward that the Natural Environment Research Council funded BRITICE-CHRONO consortium has made in dating events during deglaciation, further dating is needed, including the application of luminescence, radiocarbon and cosmogenic methods. However it is suggested that the focus of dating should now switch towards the LGM and older events. That could usefully include attempting to extend the Scottish varve chronology back beyond the Younger Dryas (McLeod et al. 2011). This, for example, could begin with detailed examination, targeteted drilling and sampling of known exposures of laminated glaciolacustrine clay concealed beneath till, such as in the Solway Lowlands (Livingstone et al. 2010a, b), the Irvine valley upstream of Kilmarnock and around Glasgow (Finlayson et al. 2010), in the catchment of the Ugie Water, in eastern Buchan (Merritt et al. 2003) and near Grantown-on-Spey (Merritt et al. 2017e). More cosmogenic ages on bedrock are required; for example, on glacially roughened and streamlined bedrock forms in order to help establish rates of glacial erosion, check for cosmogenic inheritance, and attempt to date glacial lineations formed before the LGM. Attempts could also be made to date shore platforms covered by till (Smith et al. 2018). However, any new work should involve detailed lithostratigraphy as morphostratigraphy alone is of limited value for sediment sequences. Long-term programmes of section logging during major construction projects are required together with sampling boreholes.

The coverage of detailed litho- and morph-stratigraphic investigations remains patchy. Large parts of Sutherland, Easter Ross, the Outer Hebrides, the Eastern Grampians, Angus, Lothian, the Borders and the Tweed catchment lack recent published work. We observe that the focus of BRITICE-CHRONO and recent dating has been on glacial environments and specifically on ice limits. Relatively little attention has been given to Late Pleistocene nonglacial environments during the last 25 years. For example, there are readily accessible exposures of glacially transported rafts of marine and glaciomarine sediment, raised beaches on Lewis, Barra and Vatersay, Hoy and Kintyre, and buried periglacial soils and structures in Buchan and elsewhere. Old records of organic remains, including peat and bones found below, or within the Wilderness Till in the central lowlands (Sutherland 1984), represent targets for new studies.

\section{Conclusions}

Our knowledge of the sequence of events that have occurred during the last glacialinterglacial cycle in Scotland has vastly improved over the past 25 years, with ten or more separate events now identified in some regions. Research has benefitted from the development and application of a systematic approach to lithostratigraphy, digital surface models, glaciological models and new dating methods, combined with access to offshore seabed mapping, geophysical datasets and sediment core records. This has enabled a more rigorous spatial and temporal framework to be developed for the differentiation and correlation of terrestrial Late Pleistocene deposits.

Few new critical sites pre-dating the Late Devensian have become available, but further research on several existing sites from Shetland and NE Scotland has clarified aspects of Ipswichian (MIS 5e) and Early Devensian (MIS 5d-4) events and environments. New offshore 
evidence has become available that indicates ice sheet glaciation of Scotland during both the Early Devensian (MIS 4) and the Middle Devensian (MIS 3) is consistent with the climate records from Greenland ice cores and the Norwegian stratigraphic record. However, the terrestrial stratigraphic record in Scotland for MIS 4 and MIS 3 is poorly resolved in space and time.

The greater part of the terrestrial evidence apparently relates to the Late Devensian (MIS 2) and broadly accords with recent computer reconstructions of the last BIIS (Boulton \& Hagdorn 2006; Hubbard et al. 2009; Patton et al. 2016, 2017). However, many truncated units of till occurring locally towards the base of glacigenic sequences are undated and could be older, like many ice-moulded landforms. The last ice sheet clearly was dynamic and probably reached its greatest thickness between 30 and $27 \mathrm{ka}$, during the local LGM (Ballantyne \& Small 2018) (Fig.1). The ice sheet had two modes of flow-pattern geometry: an early, thick (relative to topography) integrated one with a relatively simple ice-divide structure, and a later, much thinner mode of ice sheet comprising multiple dispersion centres and a more complex flow structure (Hughes et al. 2014). The changing flow patterns are reflected in the lithostratigraphy. The ice sheet was episodically warm-based and erosive, but the pattern of warm-based flow was spatially variable. One former hypothesis firmly rebutted is that there were ice-free enclaves at the LGM in Scotland; there were none. The overall picture emerging is that a dynamic glacial system, highly sensitive to climate change drivers, existed in Scotland throughout much of the Devensian, but the terrestrial record so far as known remains incomplete. Nevertheless, terrestrial stratigraphy in its various forms (litho-, chrono- and morpho-stratigraphy) will continue to be a benchmark for constraining the pattern and timing of events during the Late Pleistocene in Scotland.

The enigmatic 'high-level' shelly clay deposits located around the Scottish coast (Sutherland \& Gordon 1993a) are now all interpreted as glacially transported rafts of marine sediment rather than remnant in situ deposits formed during periods of high RSL before the Last glaciation (Sutherland 1981). Localities include Afton Lodge, in Ayrshire (Merritt et al. 2014), other localities around the coasts of the Firth of Clyde and Kintyre (Finlayson et al. 2010, 2014), the Rhins of Galloway (Peacock \& Everest 2016), Clava, near Inverness (Merritt 1992), sites along the southern coast of the Moray Firth (Merritt et al. 2003) and the North Sea coast of the Grampian Highlands (Auton et al. 2000). Much of the controversy has centred on the local field evidence of ice flow, which Sutherland (1981) concluded to be generally offshore rather than onshore as required in the rafting model. However, the subsequent research has shown that an early phase of onshore flow did indeed take place at all known sites.

Several areas offer opportunities and challenges to address current gaps in understanding. First, improvements in dating methods and their novel applications are crucial, particularly to older deposits pre-dating the LGM. They include luminescence applications, revival of amino acid racemisation dating, cosmogenic radionuclide (CRN) dating and development of new techniques. Second, digital surface models provide opportunities for refinements of morphostratigraphy and developing closer links with lithostratigraphy. Third, more detailed till provenance studies may help to clarify directions of ice movement, distances of ice transport and sediment recycling, ice movement 
indicators and rafting, recognising that the simple law of superposition does not always apply. Fourth, further applications of 3-D modelling based on borehole data in combination with lithostratigraphy and geomorphological mapping should provide new opportunities to elaborate on the dynamics and pattern of decay of the last ice sheet. Fifth, detailed field mapping is required of the geomorphology and superficial deposits in key areas that have been overlooked in recent decades (e.g., the Lothians and Fife), supported by pit excavations and coring and links with morphostratigraphy and flow patterns from digital surface models. Sixth, studies of intermontane areas (e.g., Strathspey) and loch and sea loch basins may help to elucidate the history of mountain icefields and glaciers during periods of more restricted glaciation during the Middle Devensian. Seventh, digital modellers are now challenged to produce ice sheet reconstructions that accommodate the complex event stratigraphy that has been illucidated, particularly from recent offshore surveys.

\section{Acknowledgements}

Many figures incorporate NEXTMap BritainTM imagery (DSM: digital surface model; DTM: digital terrain model) courtesy of Intermap Technologies Inc., provided by NERC via the NERC Earth Observation Data Centre. AMH thanks the Carnegie Trust for the Universities of Scotland for supporting fieldwork in northern Scotland. Some of ERC's work was undertaken when in receipt of an NERC Studentship during 1977-1980 for which he is most grateful and he would like to thank Dr Al Gemmell for his help and interest since he first worked in NE Scotland. We all thank Dr Jim Riding (BGS, Keyworth, Nottingham) for his detailed palynological analyses of tills and Dr Douglas Peacock for information, advice and support over many years. Craig Woodward is thanked for cartographic support. Dr Wishart Mitchell and an anonymous referee are thanked for their comments and constructive suggestions on earlier drafts. Jon Merritt publishes as an Honorary Research Associate of the British Geological Survey; Adrian Hall and John Gordon as Visiting Research Associates. The authors publish with the permission of the Executive Director, BGS (NERC).

\section{References}

Aalbersberg, G. \& Litt, T. 1998. Multiproxy climate reconstructions for the Eemian and Early Weichselian. Journal of Quaternary Science 13, 367-90.

Abbott, P.M., Davies, S.M., Steffensen, J.P., Pearce, N.J.G., Bigler, M., Johnsen, S.J., Seierstad, I.K., Svenssen, A., Wastegard, S. 2012. A detailed framework of marine Isotope Stages 4 and 5 volcanic events recorded in two Greenland ice-cores. Quaternary Science Reviews 36, 59-77.

Aber, J. S. 1985. The character of glaciotectonism. Geologie en Mijnbouw 64, 389-95.

Alley, R. B. \& MacAyeal, D. R. 1994. Ice-rafted debris associated with binge-purge oscillations of the Laurentide Ice Sheet. Palaeoceanography 9, 503-11.

Auton, C. A. 1990. The Middle Findhorn Valley. In Auton, C. A., Firth, C. R. \& Merritt, J. W. (eds) Beauly to Nairn: Field Guide, 74-96. Cambridge: Quaternary Research Association.

Auton, C.A. 1993. Dalcharn. In Gordon, J. E. \& Sutherland D. G. (eds) Quaternary of Scotland. Geological Conservation Review Series No. 6, 154-59. London: Chapman \& Hall. 
Auton, C. A. 1998. Aspects of the Quaternary geology of 1:50,000 Sheet 74W (Tomatin). British Geology Survey Technical Report WA/98/21.

Auton, C. A. 2003. The Quaternary and Devonian geology of Sheet 115E (Reay). British Geological Survey Commissioned Report CR/03/030.

Auton, C. A. 2017a. The Daless viewpoint in the Middle Findhorn valley. In Merritt, J. W., Auton, C. A. \& Phillips, E. R. (eds) The Quaternary around Nairn and the Inverness Firth, Scotland: Field Guide, 188-98. London: Quaternary Research Association.

Auton, C. A. 2017b. Evidence for glacial lakes at Banchor and lower in the Findhorn catchment. In Merritt, J. W., Auton, C .A. \& Phillips, E. R. (eds) The Quaternary around Nairn and the Inverness Firth, Scotland: Field Guide, 199-211. London: Quaternary Research Association.

Auton, C. A. 2017c. Grange Hill. Kinloss. In Merritt, J. W., Auton, C. A. \& Phillips, E. R. (eds) The Quaternary around Nairn and the Inverness Firth, Scotland: Field Guide, 92-100. London: Quaternary Research Association.

Auton, C. A., Gordon, J. E., Merritt, J. W. \& Walker, M. J. C. 2000. The glacial and interstadial sediments at the Burn of Benholm, Kincardineshire: evidence for onshore preDevensian ice movement in northeast Scotland. Journal of Quaternary Science 15, 14156.

Baden-Powell, D. E. W. 1938. On the glacial and interglacial marine beds of northern Lewis. Geological Magazine 75, 395-409.

Ballantyne, C. K. 2007. The Loch Lomond Readvance on north Arran: glacier reconstruction and palaeoclimatic reconstructions. Journal of Quaternary Science 22, 343-59.

Ballantyne, C. K. 2010. Extent and deglacial chronology of the last British-Irish Ice Sheet: implications of exposure dating using cosmogenic isotopes. Journal of Quaternary Science 25, 515-34.

Ballantyne, C. K. 2018. After the ice: Lateglacial and Holocene landforms and landscape evolution in Scotland. Earth and Environmental Science Transactions of the Royal Society of Edinburgh https://doi.org/10.1017/S175569101800004X

Ballantyne, C. K., Schnabel, C. \& Xu, S. 2009a. Readvance of the last British-Irish Ice Sheet during Greenland Interstade 1 (GI-1): the Wester Ross Readvance, NW Scotland. Quaternary Science Reviews 28, 783-89.

Ballantyne, C. K., Schnabel, C. \& Xu, S. 2009b. Exposure dating and reinterpretation of coarse debris accumulations ('rock glaciers') in the Cairngorm Mountains, Scotland. Journal of Quaternary Science 24, 19-31

Ballantyne, C. K., Fabel, D., Gheorghiu, D., Rodés, Á., Shanks, R. \& Xu, S. 2017. Late Quaternary glaciation in the Hebrides sector of the continental shelf: cosmogenic nuclide dating of glacial events on the St Kilda archipelago. Boreas 46, 605-21.

Ballantyne, C. K. \& Hall, A. M. 2008. The altitude of the last ice sheet in Caithness and east Sutherland, Northern Scotland. Scottish Journal of Geology 44, 169-81. 
Ballantyne, C. K. \& Small, D. 2018. The last Scottish Ice Sheet. Earth and Environmental Science Transactions of the Royal Society of Edinburgh https://doi.org/10.1017/S1755691018000038

Barrow, G., Hinxman, L. W. \& Cunningham Craig, E. H. 1913. The geology of Upper Strathspey, Gaick and the Forest of Atholl. Memoir of the Geological Survey of Scotland, Sheet 64 (Scotland). Edinburgh: HMSO.

Bell, D. 1871. On the aspects of Clydesdale during the glacial period. Transactions of the Geological Society of Glasgow 4, 63-69.

Benn, D. I. \& Dawson, A. G. 1987. A Devensian glaciomarine sequence in western Islay, Inner Hebrides. Scottish Journal of Geology 23, 175-87.

Benn, D. I. \& Evans, D. J. A. 2010. Glaciers and Glaciation (2nd Edition). London: Hodder Education.

Bennett, M.R., Huddart, D. \& Thomas, G.S.P. 2007. The Newbigging Esker System, Lanarkshire, southern Scotland: a model for composite tunnel, subaqueous fan and supraglacial esker sedimentation. In Hambrey, M.J., Christoffersen, P., Glasser, N.F. \& Hubbard, B. (eds) Glacial Sedimentary Processes and Products. 177-202. WileyBlackwell. 436pp. DOI: 10.1002/9781444304435.ch12.

Bickerdike, H. L., Ó Cofaigh, C., Evans, D. J. A. \& Stokes, C. R. 2018. Glacial landsystems, retreat dynamics and controls on Loch Lomond Stadial (Younger Dryas) glaciation in Britain. Boreas 47, 202-24.

Birks, H. J. B. 1993a. Fugla Ness. In Gordon, J. E. \& Sutherland D. G. (eds) Quaternary of Scotland. Geological Conservation Review Series No. 6, 54-58. London: Chapman \& Hall.

Birks, H. J. B. 1993b. Sel Ayre. In Gordon, J. E. \& Sutherland D. G. (eds) Quaternary of Scotland. Geological Conservation Review Series No. 6, 58-60. London: Chapman \& Hall.

Birks, H. J. B. \& Peglar, S. M. 1979. Interglacial pollen spectra from Sel Ayre, Shetland. New Phytologist 83, 559-75.

Birks, H. J. B. \& Ransom, M. E. 1969. An interglacial peat at Fugla Ness, Shetland. New Phytologist 68, 777-96.

Birnie, J. 1983. Tolsta Head: further investigations of the interstadial deposit. Quaternary Newsletter 41, 18-25.

Bos, J. A. A., Dickson, J. H., Coope, G. R. \& Jardine, W. G. 2004. Flora, fauna and climate of Scotland during the Weichselian Middle Pleniglacial - palynological, macrofossil and coleopteran investigations. Palaeogeography, Palaeoclimatology, Palaeoecology 204, 65-100.

Boulton, G. S., Smith, G. D., Jones, A. S. \& Newsome, J. 1985. Glacial geology and glaciology of the last mid-latitude ice sheets. Journal of the Geological Society of London 142, 44774.

Boulton, G. S. \& Hagdorn, M. 2006. Glaciology of the British Isles Ice Sheet during the last glacial cycle: form, flow, streams and lobes. Quaternary Science Reviews 25, 3359-90.

Bowen, D. Q. 1978. Quaternary Geology. A Stratigraphic Framework for Multidisciplinary Work. Oxford: Pergamon Press. 
Bowen, D. Q. (ed.) 1999. A revised correlation of Quaternary deposits in the British Isles. Special Report of the Geological Society of London, No. 23.

Bowen, D. Q., Philips, F. M., McCabe, A. M., Knutz, P. C. \& Sykes, G.A. 2002. New data for the Last Glacial Maximum in Great Britain and Ireland. Quaternary Science Reviews 21, 89-101.

Bowen, D. Q. \& Sykes, G. A. 1988. Correlation of marine events and glaciations on the northeast Atlantic margin. Philosophical Transactions of the Royal Society of London B318, 619-635.

Bradwell, T. 2003. The Quaternary deposits and glacial history of the area around Inchnadamph, Sutherland. British Geological Survey Internal Report IR/03/120.

Bradwell, T. 2005. Bedrock megagrooves in Assynt, NW Scotland. Geomorphology 65, 195204.

Bradwell, T. 2010a. Allt an t-Srathain. In Lukas, S. \& Bradwell, T. (eds) The Quaternary of Western Sutherland and Adjacent Areas: Field Guide, 111-17. London: Quaternary Research Association.

Bradwell, T. 2010b. Strath Canaird: glaciofluvial terraces and Lateglacial sea levels. In Lukas, S. \& Bradwell, T. (eds) The Quaternary of Western Sutherland and Adjacent Areas: Field Guide, 123-27. London: Quaternary Research Association.

Bradwell, T., Stoker, M. \& Larter, R. 2007. Geomorphological signature and flow dynamics of The Minch palaeo-ice stream, northwest Scotland. Journal of Quaternary Science 22, 609-17.

Bradwell, T., Stoker, M. S., Golledge, N. R., Wilson, C., Merritt, J. W., Long, D., Everest, J. D., Hestvik, O. B., Stevenson, A., Hubbard, A., Finlayson, A. \& Mathers, H. 2008a. The northern sector of the Last British Ice Sheet: maximum extent and demise. EarthScience Reviews 88, 207-26.

Bradwell, T., Stoker, M. \& Krabbendam, M. 2008b. Megagrooves and streamlined bedrock in NW Scotland: the role of ice streams in landscape evolution. Geomorphology 97, 13556.

Bradwell, T. \& Stoker, M. S. 2010. Quaternary lithostratigraphy of the NW Highlands. In Lukas, S. \& Bradwell, T. (eds) The Quaternary of Western Sutherland and Adjacent Areas: Field Guide, 29-37. London: Quaternary Research Association.

Bradwell, T. \& Stoker, M. S. 2015. Submarine sediment and landform record of a palaeo-ice stream within the British-Irish Ice Sheet. Boreas 44, 255-76.

Brazier, V., Kirkbride, M. \& Gordon, J. E. 1998. Active ice sheet deglaciation and ice-dammed lakes in the northern Cairngorm Mountains, Scotland. Boreas 27, 297-310.

Bremner, A. 1928. Further problems in the glacial geology of north-eastern Scotland. Transactions of the Edinburgh Geological Society, 12, 147-164.

Bremner, A. 1929. The glaciation of the Cairngorms. The Deeside Field 4, 29-37.

Bremner A. 1934. The glaciation of Moray and ice movements in the north of Scotland. Transactions of the Edinburgh Geological Society 13, 17-56.

Bremner, A. 1939. The River Findhorn. Scottish Geographical Magazine 55, 65-85. 
Bremner A. 1943. The glacial epoch in the north-east. In Tocher, J. F. (ed.) The Book of Buchan (Jubilee Volume), 10-30. Aberdeen: P. Scrogie Ltd \& Aberdeen University Press.

British Geological Survey 1997. 1:50 000 Sheet 84W (Fortrose) of the Geological Map of Scotland. Keyworth, Nottingham: British Geological Survey.

British Geological Survey 2002. Dalwhinnie. Scotland Sheet 63E. Solid and Drift. 1:50 000. Keyworth, Nottingham: British Geological Survey.

British Geological Survey 2004. Tomatin. Scotland Sheet 74W. Bedrock and Superficial Deposits. 1:50 000. Keyworth, Nottingham: British Geological Survey.

British Geological Survey 2005. Solway West. Scotland Special Sheet. Superficial Deposits and Simplified bedrock. 1:50 000 Geology Series. Keyworth, Nottingham: British Geological Survey.

British Geological Survey 2006. Solway East. Scotland Special Sheet. Superficial Deposits and Simplified bedrock. 1:50 000 Geology Series. Keyworth, Nottingham: British Geological Survey.

British Geological Survey 2008a. 1:50 000 Sheet 64E (Ben Macdui) of the Geological Map of Scotland. Bedrock and Superficial Deposits. Keyworth, Nottingham: British Geological Survey.

British Geological Survey 2008b. 1:50 000 Sheet 64W (Newtonmore) of the Geological Map of Scotland. Bedrock and Superficial Deposits. Keyworth, Nottingham: British Geological Survey.

British Geological Survey 2012. 1:50 000 Sheet 73W (Invermoriston) of the Geological Map of Scotland. Bedrock and Superficial Deposits. Keyworth, Nottingham.

British Geological Survey 2013. 1:50 000 Sheet 74E (Aviemore) of the Geological Map of Scotland. Bedrock and Superficial Deposits. Keyworth, Nottingham: British Geological Survey.

Brookfield, M., Merritt, J. W. \& McMillan, A. A. 2010. The Powfoot boulder pavement. In Livingstone, S. J., Evans, D. J. A. \& Ó Cofaigh, C. (eds) The Quaternary of the Solway Lowlands and Pennine Escarpment: Field Guide, 113-15. Durham: Quaternary Research Association.

Brown, E. J., Rose, J., Coope, G. R. \& Lowe, J. J. 2007. An MIS 3 age organic deposit from Balglass Burn, central Scotland: palaeoenvironmental significance and implications for the timing of the onset of the LGM ice sheet in the vicinity of the British Isles. Journal of Quaternary Science 22, 295-308.

Browne, M.A.E. 2011. The physical geography and geology of the estuary and Firth of Forth. Proceedings of the Royal Society of Edinburgh. Section B. Biological Sciences 93, 235-44.

Browne, M. A .E., Harkness, D. D., Peacock, J. D. \& Ward, R. G. 1977. The date of deglaciation of the Paisley-Renfrew area. Scottish Journal of Geology 13, 301-303.

Browne, M. A. E., Graham, D.K. \& Gregory, D.M. 1984. Quaternary estuarine deposits in the Grangemouth area. Report of the British Geological Survey 16/3.

Browne, M. A. E. \& McMillan, A. A. 1989. Quaternary geology of the Clyde valley. British Geological Survey Research Report SA/89/1. 
Cameron, I.B., Aitken, A.A., Browne, M.A.E. \& Stephenson, D. 1998. Geology of the Falkirk District: Memoir for 1:50,000 Geological Sheet 31E (Scotland). British Geological Survey. London: HMSO.

Carr, S. J., Holmes, R., van der Meer, J. J. M. \& Rose, J. 2006. The Last Glacial Maximum in the North Sea Basin: micromorphological evidence of extensive glaciation. Journal of Quaternary Science 21, 131-53.

Carr, S. J. \& Hiemstra, J. F. 2013. Sedimentary evidence against a local ice-cap on the Shetland Isles at the Last Glacial Maximum. Proceedings of the Geologists' Association 124, 484-502.

Chandler, M.P., Lovell, H., Boston, C.M., Lukas, S., Barr, I.D., Benedicktsson, I.V., Benn, D.I., Clark, C.D., Darvill, C.M., Evans, D.J.A., Ewertowski, M.W., Loibl, D., Margold, M., Otto, J-C., Roberts, D.H., Stokes, C.R., Storrar, R.D. \& Stoeven, A.P. 2018. Glacial geomorphological mapping: A review of approaches and frameworks for best practice. Earth-Science Reviews 185, 806-846.

Chapelhowe, R. 1965. On the glaciation in North Roe, Shetland. Geographical Journal 131, 60-70.

Chesher, J. A., Smythe, D. K. \& Bishop, P. 1983. The geology of the Minches, inner Sound and Sound of Raasay. Report of the Institute of Geological Sciences No. 83/6.

Chiverrell, R. C., Smedley, R. K., Small, D., Ballantyne, C. K., Burke, M. J., Callard, S. L., Clark, C. D., Duller, G. A. T., Evans, D. J. A., Fabel, D., van Landeghem, K. J. J., Livingstone, S., Ó Cofaigh, C., Thomas, G. S. P, Roberts, D. H., Saher, M., Scourse, J. D. \& Wilson, P. 2018. Ice margin oscillations during deglaciation of the northern Irish Sea Basin. Journal of Quaternary Science 33, 739-762..

Chiverrell, R. C. \& Thomas, G. S. P. 2010. Extent and timing of the Last Glacial Maximum (LGM) in Britain and Ireland: a review. Journal of Quaternary Science 25, 535-549.

Clapperton, C. M. 1997. Greenland ice cores and North Atlantic sediments: implications for the Last Glaciation in Scotland. In Gordon, J. E. (ed.), Reflections on the Ice Age in Scotland, 45-58. Glasgow: Scottish Association of Geography Teachers; Edinburgh: Scottish Natural Heritage.

Clapperton, C. M. \& Sugden, D. E. 1977. The Late Devensian glaciation of north-east Scotland. In Gray, J. M. \& Lowe, J. J. (eds) Studies in the Scottish Lateglacial Environment, 1-13. Oxford: Pergamon Press.

Clark, C. D., Evans, D. J. A., Khatwa, A., Bradwell, T., Jordan, C. J., Marsh, S. H., Mitchell, W. A. \& Bateman, M. D. 2004. Map and GIS database of glacial landforms and features related to the last British Ice Sheet. Boreas 33, 359-75.

Clark, C. D., Hughes, A. L. C., Greenwood, S. L., Jordan, C. \& Sejrup, H. P. 2012. Pattern and timing of retreat of the last British-Irish Ice Sheet. Quaternary Science Reviews 44, 11246.

Clark, C. D., Ely, J. C., Greenwood, S. L., Hughes, A. L. C., Meehan, R., Barr, I. D., Bateman, M. D., Bradwell, T., Doole, J., Evans, D. J. A., Jordan, C. J., Monteys, X., Pellicer, X. M. \& Sheehy, M. 2018. BRITICE Glacial Map, version 2: a map and GIS database of glacial landforms of the last British-Irish Ice Sheet. Boreas 47, 11-27. 
Clark, J., McCabe, A. M., Bowen, D. Q. \& Clark, P. U. 2012. Response of the Irish Ice Sheet to abrupt climate change during the last deglaciation. Quaternary Science Reviews 35, 100-15.

Clark, P. U., Dyke, A. S., Shakun, J., Carlson, A. E., Clark, J., Wohlfarth, B., Mitrovica, J. X., Hostetler, S. W. \& McCabe, A. M. 2009. The Last Glacial Maximum. Science 325, 710-14.

Connell, E. R. 2000 Tofthead, Fochabers. In Merritt, J. W., Connell, E. R. \& Bridgland, D. R. (eds) The Quaternary of the Banffshire coast and Buchan: Field Guide, 38-39. London: Quaternary Research Association.

Connell, E. R. \& Hall, A. M. 1987. The periglacial stratigraphy of Buchan. In Boardman, J. (ed.) Periglacial Processes and Landforms in Britain and Ireland, 277-285. Cambridge: Cambridge University Press.

Cousins, R. 2012. The glaciation history of Islay: implications for ice sheet dynamics in southwest Scotland. Unpublished PhD Thesis, University of Edinburgh, UK.

Crampton, C. B. \& Carruthers, R. G. 1914. The Geology of Caithness. Memoirs of the Geological Survey of Scotland. Edinburgh: HMSO.

Croll, J. 1870. The boulder clay of Caithness a product of land ice. Geological Magazine 7, 209-14, 271-78.

Dahlgren, K. I. T. \& Vorren, T. O. 2003. Sedimentary environment and glacial history during the last $40 \mathrm{ka}$ of the Voring continental margin, mid-Norway. Marine Geology 193, 93127.

Davies, B. J., Roberts, D. H., Bridgland, D. R., Ó Cofaigh, C. \& Riding, J. B. 2011. Provenance and depositional environments of Quaternary sediments from the western North Sea Basin. Journal of Quaternary Science 26, 59-75.

Davison, S. 2004. Reconstructing the last Pleistocene (Late Devensian) glaciation on the continental margin of Northwest Britain. Unpublished PhD Thesis, University of Edinburgh, UK.

Dawson, A. G. 1982. Lateglacial sea-level changes and ice-limits in Islay, Jura and Scarba, Scottish Inner Hebrides. Scottish Journal of Geology 18, 253-65.

Dawson, A. G., Benn, D. I. \& Dawson, S. 1997. Late Quaternary glaciomarine sedimentation in the Rhinns of Islay, Scottish Inner Hebrides. In Dawson, A. G. \& Dawson, S. (eds) The Quaternary of Islay and Jura: Field Guide, 66-77. Cambridge: Quaternary Research Association.

Day, J. B. W. 1970. The geology of the country around Bewcastle. Geological Survey Memoir, England and Wales, Sheet 12. Institute of Geological Sciences. London: Her Majesty's Stationery Office.

Dixon, E. E. L., Maden, J., Trotter, F. M., Hollingworth, S. E. \& Tonks, L. H. 1926. The geology of the Carlisle, Longtown and Silloth District. Memoir of the Geological Survey. Explanation of Sheets 11, 16 and 17 (England and Wales). London: HMSO.

Duller, G. A. T., Wintle, A. F. \& Hall, A. M. 1995. Luminescence dating and its application to key pre-Late Devensian sites in Scotland. Quaternary Science Reviews 14, 495-519. 
Dunlop, P., Shannon, R., McCabe, A. M., Quinn, R. \& Doyle, E. 2010. Marine geophysical evidence for ice sheet extension and recession on the Malin Shelf: New evidence for the western limits of the British Irish Ice Sheet. Marine Geology 276, 86-99.

Entwisle, D. C. \& Wildman, G. 2010. Creation of the Till Thematic Layer. British Geological Survey Internal Report IR/10/041, $14 \mathrm{pp}$.

Evans, D. J. A., Clark, C. D. \& Mitchell, W. A. 2005. The last British ice sheet: a review of the evidence utilized in the compilation of the glacial map of Britain. Earth-Science Reviews 70, 253-312.

Everest, J., Bradwell, T. \& Golledge, N. 2005. Subglacial landforms of the Tweed Palaeo- Ice Stream. Scottish Landform Example, No. 35. Scottish Geographical Magazine 121, 16373.

Eyles, V. A., Simpson, J. B. \& MacGregor, A. G. 1949. Geology of Central Ayrshire. Memoirs of the Geological Survey Scotland. Edinburgh: HMSO.

Finlay, T. M. 1926. A tongsbergite boulder from the boulder-clay of Shetland. Transactions of the Edinburgh Geological Society 12, 180.

Finlayson, A. 2012. Ice dynamics and sediment movement: last glacial cycle, Clyde basin, Scotland. Journal of Glaciology 58, 487-500.

Finlayson, A., Merritt, J., Browne, M., Merritt, J., McMillan, A. \& Whitbread, K. 2010. Ice sheet advance, dynamics and decay configurations: evidence from west central Scotland. Quaternary Science Reviews 29, 969-88.

Finlayson, A., Fabel, D., Bradwell, T. \& Sugden, D. 2014. Growth and decay of a marine terminating sector of the last British Irish Ice Sheet. Quaternary Science Reviews 83, 28 45.

Firth, C.R., 1989. Late Devensian raised shorelines and ice limits in the inner Moray Firth area, northern Scotland. Boreas, 18, 5-21.

Firth, C. R. \& Haggart, B. A. 1989. Loch Lomond Stadial and Flandrian shorelines in the inner Moray Firth area, Scotland. Journal of Quaternary Science 4, 37-50.

Fletcher, T. P., Auton, C. A., Highton, A. J., Merritt, J. W., Robertson, S. \& Rollin, K. E. 1996. Geology of the Fortrose and Eastern Inverness District. Memoir of the British Geological Survey, Sheet 84W (Scotland). London: HMSO.

Flinn, D. 1978. The most recent glaciation of the Orkney-Shetland Channel and adjacent areas. Scottish Journal of Geology 14, 109-23.

Flinn, D. 1983. Glacial meltwater channels in the northern isles of Shetland. Scottish Journal of Geology 19, 311-20.

Flinn, D. 2009. The omission of conflicting evidence from the paper by Golledge et al. (2008). Geografiska Annaler 91A, 253-56.

Forsyth, I. H., Hall, I. H. S. \& McMillan, A. A. 1996. Geology of the Airdrie district. Memoir of the British Geological Survey, Sheet 31W (Scotland). London: HMSO.

Geikie, J. 1873. On the glacial phenomena of the Long Island or Outer Hebrides. First Paper. Quarterly Journal of the Geological Society 29, 532-45. 
Geikie, J. 1878. On the glacial phenomena of the Long Island or Outer Hebrides. Second Paper. Quarterly Journal of the Geological Society 34, 819-70.

Gemmell, A. M. D. 1973. The deglaciation of the Island of Arran, Scotland. Transactions of the Institute of British Geographers 59, 25-39.

Gemmell, A. M. D., Murray, A. S. \& Connell, E. R. 2007. Devensian glacial events in Buchan (NE Scotland): a progress report on new OSL dates and their implications. Quaternary Geochronology 2, 237-42.

Gemmell, A. M. D. \& Ralston, I. B. M. 1984. Some recent discoveries of ice-wedge cast networks in north-east Scotland. Scottish Journal of Geology 20, 115-18.

Gibbard, P. L. \& Clark, C. D. 2011. Pleistocene glaciation limits in Great Britain. In: Gibbard, P. L. \& Hughes, P. D. (eds) Quaternary Glaciations - Extent and Chronology. A Closer Look. Developments in Quaternary Science 15, 75-93. Amsterdam: Elsevier.

Gibbard, P. L. \& Lewin, J. 2016. Partitioning the Quaternary. Quaternary Science Reviews $151,127-39$.

Goldthwaite, R.P. 1979. Giant grooves made by concentrated basal ice streams. Journal of Glaciology 23, 297-307.

Golledge, N. R., Finlayson, A., Bradwell, T. \& Everest, J. D. 2008. The last glaciation of Shetland, North Atlantic. Geografiska Annaler 90A, 37-53.

Golledge, M. R. \& Stoker, M. S. 2006. A palaeo-ice stream of the British Ice Sheet in eastern Scotland. Boreas 35, 231-43.

Gordon, J. E. 1993a. The glaciation of Caithness. In Gordon, J. E. \& Sutherland D. G. (eds) Quaternary of Scotland. Geological Conservation Review Series No. 6, 87-91. London: Chapman \& Hall.

Gordon, J. E. 1993b. Baile an t'Sratha. In Gordon, J. E. \& Sutherland D. G. (eds) Quaternary of Scotland. Geological Conservation Review Series No. 6, 91-92. London: Chapman \& Hall.

Gordon, J. E. 1993c. Drumhollistan. In Gordon, J. E. \& Sutherland D. G. (eds) Quaternary of Scotland. Geological Conservation Review Series No. 6, 92-94. London: Chapman \& Hall.

Gordon, J. E. 1993d. Leavad. In Gordon, J. E. \& Sutherland D. G. (eds) Quaternary of Scotland. Geological Conservation Review Series No. 6, 94-95. London: Chapman \& Hall.

Gordon, J. E. 1993e. Clava. In Gordon, J. E. \& Sutherland D. G. (eds) Quaternary of Scotland. Geological Conservation Review Series No. 6, 165-70. London: Chapman \& Hall.

Gordon, J. E. 1993f. Boyne Quarry. In Gordon, J. E. \& Sutherland D. G. (eds) Quaternary of Scotland. Geological Conservation Review Series No. 6, 233-36. London: Chapman \& Hall.

Gordon, J. E. 1993g. Kippet Hills. In Gordon, J. E. \& Sutherland D. G. (eds) Quaternary of Scotland. Geological Conservation Review Series No. 6, 242-45. London: Chapman \& Hall.

Gordon, J. E. 1993h. The Cairngorms. In Gordon, J. E. \& Sutherland D. G. (eds) Quaternary of Scotland. Geological Conservation Review Series No. 6, 259-76. London: Chapman \& Hall. 
Gordon, J. E. 1993i. North-west coast of Lewis. In Gordon, J. E. \& Sutherland D. G. (eds) Quaternary of Scotland. Geological Conservation Review Series No. 6, 414-21. London: Chapman \& Hall.

Gordon, J. E. 1993j. Port of Ness. In Gordon, J. E. \& Sutherland D. G. (eds) Quaternary of Scotland. Geological Conservation Review Series No. 6, 421-23. London: Chapman \& Hall.

Gordon, J. E. 1993k. Afton Lodge. In Gordon, J. E. \& Sutherland D. G. (eds) Quaternary of Scotland. Geological Conservation Review Series No. 6, 538-41. London: Chapman \& Hall.

Gordon, J. E. 1993I. Carstairs Kames. In Gordon, J. E. \& Sutherland D. G. (eds) Quaternary of Scotland. Geological Conservation Review Series No. 6, 544-549. London: Chapman \& Hall.

Gordon, J. E. 1993m. The glaciation of the Edinburgh and Lothians area. In Gordon, J. E. \& Sutherland D. G. (eds) Quaternary of Scotland. Geological Conservation Review Series No. 6, 562-65. London: Chapman \& Hall.

Gordon, J. E., Hall, A. M. \& Ross, H. M. 1993. Introduction to the Quaternary of Shetland. In Birnie, J., Gordon, J. E., Bennett, K. D. \& Hall, A. M. (eds) The Quaternary of Shetland: Field Guide, 6-8. Cambridge: Quaternary Research Association.

Gordon, J. E. \& Sutherland, D. G. (eds) 1993a. Quaternary of Scotland. Geological Conservation Review Series No. 6. London: Chapman \& Hall.

Gordon, J. E. \& Sutherland, D. G. 1993b. Tolsta Head. In Gordon, J. E. \& Sutherland D. G. (eds) Quaternary of Scotland. Geological Conservation Review Series No. 6, 423-25. London: Chapman \& Hall.

Graham, A. G., Lonergan, L. \& Stoker, M. S. 2007. Evidence for Late Pleistocene ice stream activity in the Witch Ground Basin, central North Sea, from 3D seismic reflection data. Quaternary Science Reviews 26, 627-43.

Graham, A. G., Lonergan, L. \& Stoker, M. S. 2009. Seafloor glacial features reveal the extent and decay of the last British Ice Sheet, east of Scotland. Journal of Quaternary Science 24, 117-38.

Graham, A. G., Lonergan, L. \& Stoker, M. S. 2010. Depositional environments and chronology of Late Weichselian glaciation and deglaciation in the central North Sea. Boreas 39, 471-91.

Graham, A. G., Stoker, M. S., Lonergan, L., Bradwell, T. \& Stewart, M. A., 2011. The Pleistocene glaciations of the North Sea Basin. In Ehlers, J., Gibbard, P. L. \& Hughes, P. D. (eds) Quaternary Glaciations -Extent and Chronology. A Closer Look. Developments in Quaternary Science 15, 261-78. Amsterdam: Elsevier.

Gray, J. M. 1993. Glencardoch Point. In Gordon, J. E. \& Sutherland D. G. (eds) Quaternary of Scotland. Geological Conservation Review Series No. 6, 313-16. London: Chapman \& Hall. 
Greenwood, S. L. \& Clark, C. D. 2009. Reconstructing the last Irish Ice Sheet 2: a geomorphologically-driven model of ice sheet growth, retreat and dynamics. Quaternary Science Reviews 28, 3101-23.

Hall, A. M. (ed.) 1984. Buchan Field Guide. Cambridge: Quaternary Research Association.

Hall, A. M. 1995. Was all of Lewis glaciated in the Late Devensian? Quaternary Newsletter 76, 1-7.

Hall, A. M. 1996a. Quaternary geomorphology of the Outer Hebrides. In Gilbertson, D., Kent, M. \& Grattan, J. (eds) The Outer Hebrides: the last 14,000 years, 5-12. Sheffield: Sheffield Academic Press.

Hall, A. M. 1996b. Scara Taing. In Hall, A. M. (ed.) The Quaternary of Orkney: Field Guide, 122-123. Cambridge: Quaternary Research Association.

Hall, A. M. 2013. The last glaciation of Shetland: local ice cap or invasive ice sheet? Norwegian Journal of Geology 93, 229-242.

Hall, A. M., Gordon, J. E. \& Whittington, G. 1993a. Early Devensian interstadial peat at Sel Ayre, Shetland. In Birnie, J. F., Gordon, J. E., Bennett, K. D. \& Hall, A. M. (eds) The Quaternary of Shetland: Field Guide, 104-18. Cambridge: Quaternary Research Association.

Hall, A. M., Whittington, G. \& Gordon, J. E. 1993b. Interglacial peat at Fugla Ness, Shetland. In Birnie, J. F., Gordon, J. E., Bennett, K. D. \& Hall, A. M. (eds) The Quaternary of Shetland: Field Guide, 62-76. Cambridge: Quaternary Research Association.

Hall, A. M., Whittington, G., Duller, G. A. T. \& Jarvis J. 1995a. Late Pleistocene environments in lower Strathspey, Scotland. Transactions of the Royal Society of Edinburgh: Earth Sciences 85, 253-73.

Hall, A. M., Duller, G., Jarvis, J. \& Wintle, A. G. 1995b. Middle Devensian ice-proximal gravels at Howe of Byth, Grampian Region. Scottish Journal of Geology 31, 61-64.

Hall, A. M., Gordon, J. E., Whittington, G., Duller, G. A. T. \& Heijnis, H. 2002. Sedimentology, palaeoecology and geochronology of Marine Isotope Stage 5 deposits on the Shetland Isles, Scotland. Journal of Quaternary Science 17, 51-68.

Hall, A. M., Auton, C. A., Michie, U., Pearson, S. \& Riding, J. 2011. Switching flow patterns within the last ice sheet in northern Scotland. Scottish Journal of Geology 47, 157-67.

Hall, A. M., Riding, J. B. \& Brown, J. F. 2016a. The last glaciation in Orkney, Scotland: glacial stratigraphy, event sequence and flow paths. Scottish Journal of Geology 52, 90-101.

Hall, A. M., Binnie, S. A., Sugden, D. E., Dunai, T. J. \& Wood, C. 2016b. Late readvance and rapid final deglaciation of the last ice sheet in the Grampian Mountains, Scotland. Journal of Quaternary Science 31, 869-78.

Hall, A. M., Merritt, J. W. \& Connell, E. R. \& Hubbard, A. 2018. The terrestrial record of Early and Middle Pleistocene environments, landforms and sediments in Scotland. Transactions of the Royal Society of Edinburgh: Earth Sciences DOI $10.1017 / \mathrm{S} 1755691018000713$ 
Hall, A. M. \& Connell E. R. 1991. The glacial deposits of Buchan, northeast Scotland. In Ehlers, J., Gibbard, P. L. \& Rose, J. (eds) Glacial Deposits in Great Britain and Ireland, 129-36. Rotterdam: Balkema.

Hall, A. M. \& Connell, E. R. 2000. Howe of Byth Quarry. In Merritt, J. W., Connell, E. R. \& Bridgland, D. R. (eds) The Quaternary of the Banffshire Coast and Buchan: Field Guide, 72-74. London: Quaternary Research Association.

Hall, A. M. \& Fraser, P. A. 2014. The glacial erratics of Fair Isle. Shetland Naturalist 3, 52-59.

Hall, A. M. \& Glasser, N. F. 2003. Reconstructing the basal thermal regime of an ice stream in a landscape of selective linear erosion: Glen Avon, Cairngorm Mountains, Scotland. Boreas 32, 191-207.

Hall, A. M. \& Jarvis, J. 1989. A preliminary report on the Late Devensian glaciomarine deposits around St Fergus, Grampian Region. Quaternary Newsletter 59, 5-7.

Hall, A. M. \& Jarvis, J. 1993a. Kirkhill. In Gordon, J. E. \& Sutherland D. G. (eds) Quaternary of Scotland. Geological Conservation Review Series No. 6, 225-30. London: Chapman and Hall.

Hall, A. M. \& Jarvis, J. 1993b. Bellscamphie. In Gordon, J. E. \& Sutherland D. G. (eds) Quaternary of Scotland. Geological Conservation Review Series No. 6, 230-33. London: Chapman and Hall.

Hall, A. M. \& Jarvis, J. 1995. A multiple till sequence near Ellon, Grampian Region: T.F. Jamieson's 'indigo boulder clay' re-examined. Scottish Journal of Geology 31, 53-59.

Hall, A. M. \& Peacock, J. D. 2000. King Edward. In Merritt, J. W., Connell, E. R. \& Bridgland, D. R. (eds) The Quaternary of the Banffshire Coast and Buchan: Field Guide, 43-45. London: Quaternary Research Association.

Hall, A. M. \& Riding, J. 2016. The last glaciation in Caithness, Scotland: revised till stratigraphy and ice-flow paths indicate multiple ice flow phases. Scottish Journal of Geology 52, 77-89.

Hall, A. M. \& Sugden, D. E. 1987. Limited modification of mid-latitude landscapes by ice sheets. Earth Surface Processes and Landforms 12, 531-42.

Hall, A. M. \& Whittington, G. 1989. Late Devensian glaciation of southern Caithness. Scottish Journal of Geology 25, 307-24.

Hall, I. H. S., Browne, M. A. E. \& Forsyth, I. H. 1998. Geology of the Glasgow district. Memoir of the British Geological Survey, Sheet 30E (Scotland). Edinburgh: HMSO.

Hebdon, N. J., Atkinson, T. C., Lawson, T. J. \& Young, I. R. 1997. Rate of glacial valley deepening during the Late Quaternary in Assynt, Scotland. Earth Surface Processes and Landforms 22, 305-315.

Heijnis, H. \& van der Plicht, J. 1992. Uranium/thorium dating of late Pleistocene peat deposits in NW Europe, uranium/thorium systematics and open-system behaviour of peat layers. Chemical Geology 94, 161-71.

Helle, M., Sonstegaard, E., Coope, G. R. \& Rye, N. 1981. Early Weichselian peat at Brumunddal, southeastern Norway. Boreas 10, 369-79. 
Hibbert, F., Austin, W. E. N., Leng, M. J., Gatliffe, R. W. 2010. British Ice Sheet dynamics inferred from North Atlantic ice-rafted debris records spanning the last 175000 years. Journal of Quaternary Science 25, 461-82.

Hiemstra, J. F., Shakesby, R. A. \& Vieli, A. 2015. Late Quaternary glaciation in the Hebrides sector of the continental shelf: was St Kilda overrun by the British-Irish Ice Sheet? Boreas 44, 178-96.

Hinxman, L. W. \& Anderson, E. M. 1915. The geology of Mid-Strathspey and Strathdearn, including the country between Kingussie and Grantown. Explanation of Sheet 74. Memoir of the Geological Survey of Scotland. Edinburgh: HMSO.

Holden, W. G. \& Jardine, W. G. 1980. Greenock Mains and Nith Bridge. In Jardine, W. G. (ed.) Field Guide to the Glasgow Region, 18-21. Cambridge: Quaternary Research Association.

Hollingworth, S. E. 1931. Glaciation of western Edenside and adjoining areas and the drumlins of the Edenside and Solway basin. Quarterly Journal of the Geological Society of London 87, 281-359.

Hoppe, G. 1974. The glacial history of the Shetland Islands. Institute of British Geographers Special Publication 7, 197-210.

Horne, J. 1923. The geology of the Lower Findhorn and Lower Strath Nairn. Explanation of Sheet 84 and part of 94. Memoir of the Geological Survey of Great Britain (Scotland). Edinburgh: HMSO.

Horne, J. \& Hinxman, L. W. 1914. The geology of the country around Beauly and Inverness. Memoir of the Geological Survey of Great Britain, Sheet 83 (Scotland). Edinburgh: HMSO.

Houmark-Nielsen, M. \& Kjaer, K. H. 2003. Southwest Scandinavia, 40-15 kyr BP: palaeogeography and environmental change. Journal of Quaternary Science 18, 769-86.

Hubbard, A., Bradwell, T., Golledge, N., Hall, A., Patton, H., Sugden, D., Cooper, R. \& Stoker, M. 2009. Dynamic cycles, ice streams and their impact on the extent, chronology and deglaciation of the British-Irish ice sheet. Quaternary Science Reviews 28, 758-76.

Huddart, D. 1991. The glacial history and deposits of the North and West Cumbrian lowlands. In Ehlers, J., Gibbard, P. L. \& Rose, J. (eds) Glacial Deposits in Great Britain and Ireland, 151-67. Rotterdam: Balkema.

Huddart, D. \& Bennett, M.R. 1997. The Carstairs Kames (Lanarkshire, Scotland): morphology, sedimentology and formation. Journal of Quaternary Science 12, 467-84.

Hughes, A. L. C., Clark, C. D. \& Jordan, C. J. 2010. Subglacial bedforms of the last British Ice Sheet. Journal of Maps 6, 543-63.

Hughes, A. L. C., Clark, C. D. \& Jordan C. J. 2014. Flow-pattern evolution of the last British Ice Sheet. Quaternary Science Reviews 89, 148-68.

Hughes, A. L. C., Gyllencreutz, R., Lohne, Ø. S., Mangerud, J. \& Svendsen, J. I. 2016. The last Eurasian ice sheets - a chronological database and time-slice reconstruction, DATED-1. Boreas 45, 1-45. 
Hughes, P. D., Gibbard, P. L. \& Ehlers, J. 2013. Timing of glaciation during the last glacial cycle: evaluating the concept of a global 'Last Glacial Maximum' (LGM). Earth-Science Reviews 125, 171-98.

Hughes, P. D. \& Gibbard P. L. 2015. A stratigraphical basis for the Last Glacial Maximum (LGM). Quaternary International 383, 174-85.

Jacobi, R. M., Rose, J., MacLeod, A. \& Higham, T. F. G. 2009. Revised radiocarbon ages on woolly rhinoceros (Coelodonta antiquitatis) from western central Scotland: significance for timing the extinction of woolly rhinoceros in Britain and the onset of the LGM in central Scotland. Quaternary Science Reviews 28, 2551-56.

Jamieson, T. F. 1882. On the Red Clay of the Aberdeenshire coast and the direction of icemovement in that quarter. Quarterly Journal of the Geological Society of London 38, 160-77.

Jamieson, T. F. 1906. The glacial period in Aberdeenshire and the southern border of the Moray Firth. Quarterly Journal of the Geological Society of London 62, 13-39.

Jardine, W. G., Dickson, J. H., Haughton, P. D. W., Harkness, D. D., Bowen, D. Q. \& Sykes, G. A. 1988. A late Middle Devensian interstadial site at Sourlie, near Irvine, Strathclyde. Scottish Journal of Geology 24, 288-95.

Jehu, T. J. \& Craig, R. M. 1925. The geology of the Outer Hebrides- Part II. South Uist and Eriskay. Transactions of the Royal Society of Edinburgh 53, 615-41.

Johnson, H., Richards, P. C., Long, D. \& Graham, C. C. 1993. United Kingdon Offshore Regional Report: the Geology of the Northern North Sea. London: HMSO.

Kearsey, T.I., Lee, J.R., Finlayson, A., Garcia-Bajo, M. \& Irving, A.M. 2018. Examining the geometry, age and genesis of buried Quaternary valley systems in the Midland Valley of Scotland, UK. Boreas. DOI 10.1111/bor.12364

Kehew, A. E., Piotrowski, J.A. \& Jørgensen, F. 2012. Tunnel valleys: concepts and controversies - A review. Earth-Science Reviews 113, 33-58.

Kitchener, A. C. \& Bonsall, C. 1997. AMS radiocarbon dates on some extinct Scottish mammals. Quaternary Newsletter 83, 1-11.

Kleman, J. 1994. Preservation of landforms under ice sheets and ice caps. Geomorphology 9, 19-32.

Knutz, P. C., Austin, W. E. N. \& Jones, E. J. W., 2001. Millennial-scale depositional cycles related to British Ice Sheet variability and North Atlantic paleocirculation since $45 \mathrm{kyr}$ BP, Barra Fan, U.K. margin. Paleoceanography 16, 53-64.

Krabbendam, M., Eyles, N., Putkinen, N., Bradwell, T., Arbelaez-Moreno, L. 2016. Streamlined hard beds formed by palaeo-ice streams: A review. Sedimentary Geology 338, 24-50.

Krabbendam, M. \& Bradwell, T. 2014. Quaternary evolution of glaciated gneiss terrains: preglacial weathering vs. glacial erosion. Quaternary Science Reviews 95, 20-42.

Lambeck, K., Rouby, H., Purcell, A., Sun, Y. \& Sambridge, M. 2014. Sea level and global ice volumes from the Last Glacial Maximum to the Holocene. PNAS 111, 15296-303. 
Larsen, E. \& Mangerud, J. 1989. Marine caves: on-off signals for glaciation. Quaternary International 3/4, 13-19.

Larsen, N. K., Knudsen, K. L., Krohn, C. F., Kronborg, C., Murray, A. S. \& Nielsen, O. B. 2009. Late Quaternary ice sheet, lake and sea history of southwest Scandinavia -a synthesis. Boreas 38, 732-61.

Latham, A. \& Ford, D. 2013. Chronology of the caves. In Waltham, A. \& Lowe, D. (eds) Caves and Karst of the Yorkshire Dales, 169-80. Nottingham: British Cave Research Association.

Lawson, T. J. 1993. Creag nan Uamh. In Gordon, J. E. \& Sutherland D. G. (eds) Quaternary of Scotland. Geological Conservation Review Series No. 6, 54-58. London: Chapman \& Hall.

Lawson, T. J. 1995a. The Creag nan Uamh Caves. In Lawson, T. J. (ed.) The Quaternary of Assynt and Coigach: Field Guide, 87-103. Cambridge: Quaternary Research Association.

Lawson, T. J. 1995b. An analysis of sediments in caves in the Assynt area, N.W. Scotland. Cave and Karst Science 22, 3-30.

Lawson, T. J. 2010. The Allt nan Uamh valley and its caves: their significance for the chronology of glaciation and deglaciation of northern Scotland. In Lukas, S. \& Bradwell, T. (eds) The Quaternary of Western Sutherland and Adjacent Areas: Field Guide, 165-68. London: Quaternary Research Association.

Lawson, T. J., Young, I. R., Kitchener, A. C. \& Birch, S. 2014. Middle and Late Devensian radiocarbon dates from the Uamh an Claonaite cave system in Assynt, Scotland. Quaternary Newsletter 133, 4-10.

Lawson, T. J. \& Atkinson, T. C. 1995. Quaternary chronology. In Lawson, T. J. (ed.) The Quaternary of Assynt and Coigach: Field Guide, 12-18. Cambridge: Quaternary Research Association.

Lisiecki, L. E. \& Raymo, M. E. 2005. A Plio-Pleistocene stack of 57 globally distributed benthic $\delta^{18}$ O records. Paleoceanography 20, PA1003, doi: 10.1029/2004PA001071.

Livingstone, S. J., Ó Cofaigh, C. \& Evans, D. J. A. 2008. Glacial geomorphology of the central sector of the last British-Irish Ice Sheet. Journal of Maps 4, 358-77.

Livingstone, S. J., Ó Cofaigh, C., Evans, D. J. A. \& Palmer, A. 2010a. Glaciolacustrine sedimentation in the Solway Lowlands (Cumbria, UK): evidence for a major glacial oscillation during Late Devensian deglaciation. Boreas 39, 505-27.

Livingstone, S. J. Evans, D. J. A. \& Ó Cofaigh, C. 2010b. Re-advance of Scottish ice into the Solway Lowlands (Cumbria, UK) during the Main Late Devensian deglaciation. Quaternary Science Reviews 29, 2544-70.

Livingstone, S. J., Ó Cofaigh, C. \& Evans, D. J. A. 2010c. A major ice drainage pathway of the last British-Irish Ice Sheet: the Tyne Gap, northern England. Journal of Quaternary Science 25, 354-70.

Livingstone, S. J., Evans, D. J. A., O'Cofaigh, C., Davies, B. J., Merritt, J. W., Huddart, D., Mitchell, W. A., Roberts, D. H. \& Yorke, L. 2012. Glaciodynamics of the central sector of the last British-Irish Ice Sheet in Northern England. Earth-Science Reviews 111, 25-55. 
Livingstone, S. J., Roberts, D. H., Davies, B .J. \& Evans, D. J. A. 2017. Deglaciation of the Forth and Tay palaeo-ice stream corridors, southern Scotland. Quaternary Newsletter 143, $26-29$.

Long, D. \& Skinner, A. C. 1985. Glacial meltwater channels in the northern isles of Shetland: comment. Scottish Journal of Geology 21, 222-24.

Lowe, J. J., Albert, A., Hardiman, M., MacLeod, A., Blockley, S. \& Pyne-O’Donnell, S. 2008a. Tephrostratigraphical investigations of the basal sediment sequence at Loch Etteridge. In Palmer, A. P., Lowe, J. J. \& Rose, J. (eds) The Quaternary of Glen Roy and Vicinity: Field Guide, 60-73. London: Quaternary Research Association.

Lowe, J. J., Rasmussen, S. O., Björk, S., Hoek, W. Z., Steffensen, J. P., Walker, M. J. C., Yu, Z. C. $\&$ the INTIMATE group 2008b. Synchronisation of palaeoenvironmental events in the North Atlantic region during The Last Termination: a revised protocol recommended by the INTIMATE group. Quaternary Science Reviews 27, 6-17.

Lowe, J. \& Walker, M. 2015. Reconstructing Quaternary Environments (3rd Edition). Abingdon and New York: Routledge.

Lukas, S. 2010. Evidence of an ice-marginal oscillation during ice-sheet deglaciation: the Shinness moraine. In Lukas, S. \& Bradwell, T. (eds) The Quaternary of Western Sutherland and Adjacent Areas: Field Guide, 181-85. London: Quaternary Research Association.

Lukas, S. \& Bradwell, T. (eds) 2010. The Quaternary of Western Sutherland and Adjacent Areas: Field Guide. London: Quaternary Research Association.

Lumsden, G. I., Tulloch, W., Howells, M. F. \& Davies, A. 1967. The Geology of the neighbourhood of Langholm. Memoir of the Geological Survey of Great Britain, Sheet 11 (Scotland). Edinburgh: HMSO.

Mackie, W. 1905. Some notes on the distribution of erratics over eastern Moray. Transactions of the Edinburgh Geological Society 8, 91-97.

Mangerud, J. 2004. Ice sheet limits in Norway and on the Norwegian continental shelf. In Ehlers, J. \& Gibbard, P. L. (eds) Quaternary Glaciations - Extent and Chronology. Part I: Europe. Developments in Quaternary Science 2, 271-94. Amsterdam: Elsevier.

Mangerud, J., Gyllencreutz, R., Lohne, Ö. \& Svendsen, J. I. 2011. Glacial history of Norway. In Ehlers, J., Gibbard, P. L. \& Hughes, P. D. (eds) Quaternary Glaciations - Extent and Chronology. A Closer Look. Developments in Quaternary Science 15, 279-98. Amsterdam: Elsevier.

McCabe, A. M., Clark, P. U., Smith, D. E. \& Dunlop, P. 2007a. A revised model for the last deglaciation of eastern Scotland. Journal of the Geological Society of London 164, 31316.

McCabe, A. M., Clark, P. U., Clark. J. \& Dunlop, P. 2007b. Radiocarbon constraints on readvances of the British-Irish Ice Sheet in the northern Irish Sea Basin during the last deglaciation. Quaternary Science Reviews 26, 1204-11.

McCabe, A. M. \& Williams, G. D. 2012. Timing of the East Antrim Coastal Readvance: phase relationships between lowland Irish and upland Scottish ice sheets during the Last Glacial Termination. Quaternary Science Reviews 58, 18-29. 
McLeod, A., Palmer, A., Lowe, J. J., Rose, J., Bryant, C. \& Merritt, J. W. 2011. Timing of glacier response to Younger Dryas climatic cooling in Scotland. Global and Planetary Change 79, 264-74.

McMillan, A. A., Hamblin, R. J. O. \& Merritt, J. W. 2011a. A lithostratigraphical framework for onshore Quaternary and Neogene (Tertiary) superficial deposits of Great Britain and the Isle of Man. British Geological Survey Research Report RR/10/03.

McMillan, A. A., Merritt, J. W., Auton, C. A. \& Golledge, N. R. 2011b. The Quaternary Geology of the Solway. British Geological Survey Research Report RR/11/04.

McMillan, A.A. \& Browne, M.A.E. 1983. Glaciotectonic structures at Bellshill, east end of Glasgow. Quaternary Newsletter 40, 1-6.

McMillan, A. A. \& Merritt, J. W. 2012. A new Quaternary and Neogene lithostratigraphical framework for Great Britain and the Isle of Man. Proceedings of the Geologists' Association 123, 679-91.

Menzies, J. 1976. The glacial geomorphology of Glasgow with particular reference to the drumlins. Unpublished PhD thesis, University of Edinburgh.

Menzies, J. 1981. Investigations into the Quaternary deposits and bedrock topography of central Glasgow. Scottish Journal of Geology 17, 155-68.

Merritt, J. W. 1992. The high-level marine shell-bearing deposits of Clava, Inverness-shire, and their origin as glacial rafts. Quaternary Science Reviews 11, 759-77.

Merritt, J.W. 1993. Allt Odhar. In Gordon, J. E. \& Sutherland D. G. (eds) Quaternary of Scotland. Geological Conservation Review Series No. 6, 159-65. London: Chapman \& Hall.

Merritt, J. W. 1999. The Quaternary geology of the Dalwhinnie District. British Geological Survey Technical Report WA/99/14R.

Merritt, J. W. 2004a. The glacial stratigraphy along the southern margin of the Gaick Plateau. In Lukas, S., Merritt, J. W. \& Mitchell, W. A. (eds) The Quaternary of the Central Grampian Highlands: Field Guide, 58-67. London: Quaternary Research Association.

Merritt, J. W. 2004b. The pattern of deglaciation across the Gaick Plateau. In Lukas, S., Merritt, J. W. \& and Mitchell, W. A. (eds) The Quaternary of the Central Grampian Highlands: Field Guide, 133-38. London: Quaternary Research Association.

Merritt, J. W. 2010. Evidence for a stillstand or minor glacial readvance at Powfoot, near Annan. In Livingstone, S. J., Evans, D. J. A. \& Ó Cofaigh, C. (eds) The Quaternary of the Solway Lowlands and Pennine Escarpment: Field Guide, 109-12. London: Quaternary Research Association.

Merritt, J. W. 2017a. The Beum a' Chlaidheimh Breach and the Dulnain-Findhorn divide. In Merritt, J. W., Auton, C. A. \& Phillips, E. R. (eds) The Quaternary around Nairn and the Inverness Firth, Scotland: Field Guide, 212-21. London: Quaternary Research Association,.

Merritt, J. W. 2017b. The Allt Odhar (Moy) Interstadial site. In Merritt, J. W., Auton, C. A. \& Phillips, E. R. (eds) The Quaternary around Nairn and the Inverness Firth, Scotland: Field Guide, 176-83. London: Quaternary Research Association. 
Merritt, J. W., Auton, C. A. \& Firth, C. R. 1995. Ice-proximal glaciomarine sedimentation and sea-level change in the Inverness area, Scotland: A review of the deglaciation of a major ice stream of the British Late Devensian ice sheet. Quaternary Science Reviews 14, 289329.

Merritt, J. W., Auton, C. A., Connell, E .R., Hall, A. M. \& Peacock, J. D. 2003. Cainozoic Geology and Landscape Evolution of North-East Scotland. Memoir of the British Geological Survey (Scotland). Edinburgh: British Geological Survey.

Merritt, J. W., Lukas, S. \& Mitchell, W. A. 2004. Introduction. In Lukas, S., Merritt, J. W. \& and Mitchell, W. A. (eds) The Quaternary of the Central Grampian Highlands: Field Guide, 1-17. London: Quaternary Research Association.

Merritt, J. W., Auton, C. A., Boston, C. M., Everest, J. D. \& Merritt, J. E. 2013. An overview of main Late Devensian glaciation of the Central Grampian Highlands. In Boston, C. M., Lukas, S. \& Merritt, J. W. (eds) The Quaternary of the Monadhliath Mountains and the Great Glen: Field Guide, 25-40. London: Quaternary Research Association.

Merritt, J. W., Akhurst, M. C., Wilkinson, I. P., Riding, J. B., Phillips, E. R., Smith, R. A., Finlayson, A. \& Dean, M. T. 2014. The Late Pleistocene Afton Lodge Clay Formation, Ayrshire, Scotland: Evidence for Early to Middle Devensian climatic changes and Late Devensian onshore ice flow and rafting from the Firth of Clyde. Proceedings of the Geologists' Association 125, 195-214.

Merritt, J. W., Connell, E. R. \& Hall, A. M. 2017a. Middle to Late Devensian glaciation of north-east Scotland: implications for the north-eastern quadrant of the last British-Irish ice sheet. Journal of Quaternary Science 32, 276-94.

Merritt, J. W., Auton, C. A. and Firth, C. R. 2017b. An introduction to the history of glaciation and sea-level around Nairn and south of the Inner Moray Firth. In Merritt, J.W., Auton, C. A. \& Phillips, E. R. (eds) The Quaternary around Nairn and the Inverness Firth, Scotland: Field Guide, 28-53. London: Quaternary Research Association.

Merritt, J. W., Auton, C. A. \& Firth, C. R. 2017c. Ardersier Peninsula and the Ardersier Silts Formation. In Merritt, J. W., Auton, C. A. \& Phillips, E. R. (eds) The Quaternary around Nairn and the Inverness Firth, Scotland: Field Guide, 62-76. London: Quaternary Research Association.

Merritt, J. W., Auton, C. A. \& Finlayson, A. 2017d. Transverse ridges around Mosstowie, near Elgin, and elsewhere around the Inner Moray Firth. In Merritt, J. W., Auton, C. A. \& Phillips, E. R. (eds) The Quaternary around Nairn and the Inverness Firth, Scotland: Field Guide, 101-107. London: Quaternary Research Association.

Merritt, J. W., Merritt, J. E. \& Bradwell, T. 2017e. The glaciolacustrine and roches moutonnées sites at Dulnain Bridge. In Merritt, J. W., Auton, C. A. \& Phillips, E. R. (eds) The Quaternary around Nairn and the Inverness Firth, Scotland: Field Guide, 222-30. London: Quaternary Research Association.

Merritt, J. W., Roberson, S. \& Cooper, M. R. 2018. A critical review and re-investigation of the Pleistocene deposits between Cranfield Point and Kilkeel, Northern Ireland: Implications for regional sea-level models and glacial reconstructions of the northern Irish Sea basin. Proceedings of the Geologists Association 129, 583-609. 
Merritt, J. W. \& Auton, C.A. 1993. Notes on exposures and natural sections in drift deposits occurring on Geological Sheet 84W (Fortrose), SE of Inverness, Scotland. British Geological Survey Technical Report WA/93/28R, 237pp.

Merritt, J. W. \& Auton, C. A. 2000. An outline of the lithostratigraphy and depositional history of Quaternary deposits in the Sellafield district, west Cumbria. Proceedings of the Yorkshire Geological Society 53, 129-154.

Merritt, J. W. \& Auton, C. A. 2017. The Dalcharn Interglacial site. In Merritt, J. W., Auton, C. A. \& Phillips, E. R. (eds) The Quaternary around Nairn and the Inverness Firth, Scotland: Field Guide, 132-44. London: Quaternary Research Association.

Merritt, J. W. \& Connell, E. R. 2000a. Oldmill Quarry. In Merritt, J. W., Connell, E. R. \& Bridgland, D. R. (eds) The Quaternary of the Banffshire Coast and Buchan: Field Guide, 68-71. London: Quaternary Research Association.

Merritt, J. W. \& Connell, E. R. 2000b. The Ardglassie rafts. In Merritt, J. W., Connell, E. R. \& Bridgland, D. R. (eds) The Quaternary of the Banffshire Coast and Buchan: Field Guide, 75-78. London: Quaternary Research Association.

Merritt, J. W. \& Firth, C. R. 2017. Alturlie Point and the Alturlie Gravels Formation. In Merritt, J. W., Auton, C. A. \& Phillips, E. R. (eds) The Quaternary around Nairn and the Inverness Firth, Scotland: Field Guide, 54-61. London: Quaternary Research Association.

Merritt, J. W. \& Peacock, J. D. 2000. Glacial meltwater channels in Banffshire and Buchan. In Merritt, J. W., Connell, E. R. \& Bridgland, D. R. (eds) The Quaternary of the Banffshire Coast and Buchan: Field Guide, 46-48. London: Quaternary Research Association.

Merritt, J. W. \& Phillips, E. R. 2010. Plumpe Farm Section: stratigraphic evidence for the Scottish Readvance. In Livingstone, S. J., Evans, D. J. A. \& Ó Cofaigh, C. (eds) The Quaternary of the Solway Lowlands and Pennine Escarpment: Field Guide, 104-108. London: Quaternary Research Association.

Merritt, J. W. \& Phillips, E. R. 2017. The glacial rafts at Clava. In Merritt, J. W., Auton, C. A. \& Phillips, E. R. (eds) The Quaternary around Nairn and the Inverness Firth, Scotland: Field Guide, 145-68. London: Quaternary Research Association.

Miller, G. H., Jull, A.J.T., Linick, T., Sutherland, D., Sejrup, H.P., Brigham, J.K., Bowen, D.Q., Mangerud, J. 1987. Racemization-derived late Devensian temperature reduction in Scotland. Nature 326, 593-95.

Milne-Home, D. 1881. V. On the glaciation of the Shetlands. Geological Magazine (Decade II) 8, 205-12.

Mitchell, W. A. 2008. Quaternary geology of part of the Kale Water catchment, Western Cheviot Hills, southern Scotland. Scottish Journal of Geology 44, 51-63.

Mitchell, W. A. 2013. Glaciation and Quaternary evolution. In Waltham, A. \& Lowe, D. (eds) Caves and Karst of the Yorkshire Dales, 29-64. Nottingham: British Cave Research Association.

Mykura, W. \&, Phemister, J. 1976. The Geology of Western Shetland. London: HMSO.

NGRIP Members 2004. High-resolution record of Northern Hemisphere climate extending into the last interglacial; period. Nature 431, 147-51. 
Nickless, E. F. P., Aitken, A. M. \& McMillan, A. A. 1978. The Sand and Gravel Resources of the Country around Darvel, Strathclyde. Description of Parts of 1:20,000 Sheets NS 53, 54, 63 \& 64. Mineral Assessment Report 35. London: Institute of Geological Sciences, HMSO.

Omand, D. 1973. The glaciation of Caithness. Unpublished MSc thesis, University of Strathclyde.

Otvos, E. G. 2015 The Last Interglacial Stage: definitions and marine highstand, North America and Eurasia. Quaternary International 383, 158-73.

Parthasarathy, A. \& Blyth, G.H. 1959. The superficial deposits of the buried valley of the River Devon near Alva, Clackmannan, Scotland. Proceedings of the Geologists' Association 70, 33-50.

Paterson, I. B., McAdam, A. D. \& MacPherson, K. A. T. 1998. Geology of the Hamilton District. Memoir for 1:50,000 Geological Sheet 23W (Scotland). London: British Geological Survey, HMSO.

Patton, H., Hubbard, A., Andreassen, K., Winsbarrow, M., Stroeven, A. P. 2016. The build-up, configuration and dynamical sensitivity of the Eurasian ice-sheet complex to Late Weichselian climatic and oceanic forcing. Quaternary Science Reviews 153, 97-121.

Patton, H., Hubbard, A., Andreassen, K., Auriac, A., Whitehouse, P. L., Stroeven, A. P., Shackleton, C., Winsbarrow, M., Heyman, J. \& Hall, A. M. 2017. Deglaciation of the Eurasian ice sheet complex. Quaternary Science Reviews 169, 148-72.

Peach, B. N., 1909. Boulder distribution from Lennoxtown, Scotland. Geological Magazine 46, 26-31.

Peach, B. N. \& Horne, J. 1879. The glaciation of the Shetland Isles. Quarterly Journal of the Geological Society 35, 778-811.

Peach, B. N. \& Horne, J. 1880. The glaciation of the Orkney Islands. Quarterly Journal of the Geological Society 36, 648-63.

Peach, B. N. \& Horne, J. 1881. The glaciation of Caithness. Proceedings of the Royal Physical Society of Edinburgh 6, 316-52.

Peach, B. N. \& Horne, J. 1893. On the occurrence of shelly boulder clay in North Ronaldshay, Orkney. Transactions of the Edinburgh Geological Society 6, 309-13.

Peacock, J. D. 1970. Some aspects of the glacial geology of west Inverness-shire. Bulletin of the Geological Survey of Great Britain 33, 43-56.

Peacock, J. D. 1971. Marine shell radiocarbon dates and the chronology of deglaciation in western Scotland. Nature Physical Science 230, 43-45.

Peacock, J.D. 1981. Report and excursion guide - Lewis and Harris. Quaternary Newsletter 35, 45-54.

Peacock, J. D. 1984. Quaternary geology of the Outer Hebrides. Report of the British Geological Survey 16(2), 1-26.

Peacock J. D. 1995. Late Devensian to Early Holocene palaeoenvironmental changes in the Viking Bank area, northern North Sea. Quaternary Science Reviews 14, 1029-42. 
Peacock, J. D. 1999. The pre-Windermere Interstadial (Late Devensian) raised marine strata of eastern Scotland and their macrofauna: a review. Quaternary Science Reviews 18, 1655-80.

Peacock, J. D. 2000a. A comment on the faunas from the Whitehills Glacigenic Formation. In Merritt, J. W., Connell, E. R. \& Bridgland, D. R. (eds) The Quaternary of the Banffshire Coast and Buchan: Field Guide, 44-45. London: Quaternary Research Association.

Peacock, J. D. 2000b. A glaciated pavement and crossing striations between Fraserburgh and Rattray Head. In Merritt, J. W., Connell, E. R. \& Bridgland, D. R. (eds) The Quaternary of the Banffshire Coast and Buchan: Field Guide, 56. London: Quaternary Research Association.

Peacock, J. D. 2003. Late Quaternary sea level change and raised marine deposits of the western Highland Boundary. A) The deglaciation of the lower Clyde valley: a brief review. In Evans, D. J. A. (ed.) The Quaternary of the Western Highland Boundary: Field Guide, 30-41. London: Quaternary Research Association.

Peacock, J. D. 2008. Late Devensian palaeoenvironmental changes in the sea area adjacent to Islay, SW Scotland: implications for the deglacial history of the island. Scottish Journal of Geology 44, 183-90.

Peacock, J. D., Berridge, N. G., Harris, A. L. \& May, F. 1968. The geology of the Elgin district. Memoir of the Geological Survey, Sheet 95 (Scotland). Edinburgh: HMSO.

Peacock, J. D., Graham, D. K., Robinson, J. E. \& Wilkinson, I. 1977. Evolution and chronology of Lateglacial marine environments at Lochgilphead, Scotland. In Gray, J. M. \& Lowe, J. J. (eds) Studies in the Scottish Lateglacial Environment, 83-100. Oxford: Pergamon.

Peacock, J. D., Armstrong, M., Browne, M. A. E. \& Stoker, M. S. 2007. Discussion on a revised model for the last deglaciation of eastern Scotland. Journal of the Geological Society of London 164, 1261-63.

Peacock, J. D. \& Connell, E. R. 2000. Glacial lakes in the valleys of the North Ugie and South Ugie. In Merritt, J. W., Connell, E. R. \& Bridgland, D. R. (eds) The Quaternary of the Banffshire Coast and Buchan: Field Guide, 49-52. London: Quaternary Research Association.

Peacock, J. D. \& Everest, J. D. 2016. Pre-Late Devensian high-arctic marine deposits in SW Scotland. Scottish Journal of Geology 46, 89-92.

Peacock, J. D. \& Merritt, J. W. 1997. Glacigenic rafting at Castle Hill, Gardenstown, and its significance for the glacial history of northern Banffshire, Scotland. Journal of Quaternary Science 12, 283-94.

Peacock, J. D. \& Merritt, J. W. 2000. Glacial deposits at the Boyne Limestone Quarry, Portsoy, and the late-Quaternary history of coastal Banffshire. Journal of Quaternary Science 15, 543-55.

Peters, C., Walden, J. \& Austin, W. E. N. 2008. Magnetic signature of European margin sediments: provenance of ice-rafted debris and the climatic response of the British ice sheet during Marine Isotope Stages 2 and 3. Journal of Geophysical Research - Earth Surface 113, F03007, doi: 10.1029/2007JF000836. 
Phillips, E. R., Merritt, J. W., Auton, C. A. \& Golledge, N. R. 2007. Microstructures in subglacial and proglacial sediments: understanding faults, folds and fabrics, and the influence of water on the style of deformation. Quaternary Science Reviews 26, 14991528.

Phillips, E., Everest, J. \& Diaz-Doce, D. 2009. Bedrock controls on subglacial distribution and geomorphological process: Evidence from the Late Devensian Irish Sea Ice Stream. Sedimentary Geology 232, 98-118.

Phillips, E. R., Hodgson, D. M. \& Emery, A. R. 2017. The Quaternary geology of the North Sea basin. Journal of Quaternary Science 32, 117-26.

Phillips, E. R. \& Auton, C. A. 2000. Micromorphological evidence for polyphase deformation of glaciolacustrine sediments from Strathspey, Scotland. In Maltman, A. J., Hubbard, B. \& Hambrey, M. J. (eds) Deformation of Glacial Materials. Geological Society, London, Special Publications 176, 279-92.

Phillips, E. R. \& Auton, C. A. 2013. Evidence for active ice retreat and ice-dammed lake formation during deglaciation at Raitts Burn. In Boston, C. M., Lukas, S. \& Merritt, J. W. (eds) The Quaternary of the Monadhliath Mountains and the Great Glen: Field Guide, 153-64. London: Quaternary Research Association.

Phillips, E. R. \& Merritt, J. W. 2008. Evidence for multiphase water-escape during rafting of shelly marine sediments at Clava, Inverness-shire, NE Scotland. Quaternary Science Reviews 27, 988-1011.

Phillips, W. M., Hall, A. M., Mottram, R., Fifield, L. K. \& Sugden, D. E. 2006. Cosmogenic ${ }^{10} \mathrm{Be}$ and ${ }^{26} \mathrm{Al}$ exposure ages of tors and erratics, Cairngorm Mountains, Scotland: Timescales for the development of a classic landscape of selective linear glacial erosion. Geomorphology 73, 222-45.

Phillips, W. M., Hall, A. M., Ballantyne, C. K., Binnie, S., Kubik, P. K. \& Freeman, S. 2008. Extent of the last ice sheet in northern Scotland tested with cosmogenic ${ }^{10} \mathrm{Be}$ exposure ages. Journal of Quaternary Science 23, 101-107.

Porter, S. C. 1989. Some geological implications of average Quaternary glacial conditions. Quaternary Research 32, 245-61.

Price, R. J. 1975. The glaciation of west central Scotland - a review. Scottish Geographical Magazine 91, 134-45.

Price, R. J. 1983. Scotland's Environment during the Last 30,000 Years. Edinburgh: Scottish Academic Press.

Rae, D. A. 1976. Aspects of glaciation in Orkney. Unpublished PhD Thesis, University of Liverpool, UK.

Railsback, L. B., Gibbard, P. L., Head, M. J., Voarintsoa, N. R. G. \& Toucanne, S. 2015. An optimized scheme of lettered marine isotope substages for the last 1.0 million years, and the climatostratigraphic nature of isotope stages and substages. Quaternary Science Reviews 111, 94-106.

Rasmussen, S. O., Bigler, M., Blockley, S. P., Blunier, T., Buchardt, S. L., Clausen, H. B., Cvijanovic, I., Dahl-Jensen, D., Johnsen, S. J., Fischer, H., Gkinis, V., Guillevic, M., Hoek, W. Z., Lowe, J. J., Pedro, J. B., Popp, T., Seierstad, I. K., Steffensen, J. P., Svensson, A. M., 
Vallelonga, P., Vinther, B. M., Walker, M. J. C., Wheatley, J. J. \& Winstrup, M. 2014. A stratigraphic framework for abrupt climatic changes during the Last Glacial period based on three synchronized Greenland ice-core records: refining and extending the INTIMATE event stratigraphy. Quaternary Science Reviews 106, 14-28.

Read, H. H. 1923. The geology of the country around Banff, Huntly and Turriff (Lower Banffshire and North-west Aberdeenshire). Memoir of the Geological Survey, Scotland, Sheets 86 and 96. Edinburgh: HMSO.

Reimer, P. J., Bard, E., Bayliss, A., Beck, J. W., Blackwell, P. G., Bronk Ramsey, C., Buck, C. E., Cheng, H., Edwards, R. L., Friedrich, M., Grootes, P. M., Guilderson, T. P., Haflidason, H., Hajdas, I., Hatté, C., Heaton, T.J., Hoffmann, D.L., Hogg, A. G., Hughen, K. A., Kaiser, K. F., Kromer, B., Manning, S. W., Niu, M., Reimer, R. W., Richards, D. A., Scott, E. M., Southon, J. R., Staff, R. A., Turney, C. S. M. \& van der Plicht, J. 2013. IntCal13 and Marine13 radiocarbon age calibration curves $0-50,000$ years cal BP. Radiocarbon 55 , 1869-87.

Rolfe, W. D. I. 1966. Woolly rhinoceros from the Scottish Pleistocene. Scottish Journal of Geology 2, 253-58.

Romans, J. C. C., Stevens, J. H. \& Robertson, I. 1966. Alpine soils of north-east Scotland. Journal of Soil Science 17, 184-99.

Rose, J. 1981. Field guide to the Quaternary geology of the south-eastern part of the Loch Lomond basin. Proceedings of the Geological Society of Glasgow 122/123, 12-28.

Rose, J. 1987. Drumlins as part of a glacier bedform continuum. In Menzies, J. \& Rose, J. (eds) Drumlin Symposium, 103-16. Rotterdam: Balkema.

Rose, J. 1989. Stadial type sections in the British Quaternary. In Rose, J. \& Schlüchter, C. (eds) Quaternary Type Sections: Imagination or Reality, 45-67. Rotterdam: Balkema.

Rose, J. 2003. Geilston: Lateglacial and Holocene sea level change In Evans, D. J. A. (ed.) The Quaternary of the Western Highland Boundary: Field Guide, 30-41. London: Quaternary Research Association.

Rose, J., Lowe, J. J. \& Switsur, R. 1988. A radiocarbon date on plant detritus beneath till from the type area of the Loch Lomond Readvance. Scottish Journal of Geology 24, 113-124.

Rose, J. \& Letzer, J.M. 1977. Superimposed drumlins. Journal of Glaciology 18, 471-80.

Rose, J. \& Smith, M. J. 2008. Glacial geomorphological maps of the Glasgow region, western central Scotland. Journal of Maps 4, 399-416.

Ross, H. M. 1996. The last glaciation of Shetland. Unublished PhD Thesis, University of St. Andrews, UK.

Ross, H. M., Hall, A. M. \& Gordon, J. E. 1993. Patterns of ice flow on Shetland. In Birnie, J., Gordon, J. E., Bennett, K. D. \& Hall, A. M. (eds) The Quaternary of Shetland: Field Guide, 9-14. Cambridge: Quaternary Research Association.

Salt, K. E. \& Evans, D. J. A. 2004. Scottish landform example 32: superimposed subglacially streamlined landforms of southwest Scotland. Scottish Geographical Journal 120, 133147. 
Scourse, J. D., Haapaniemi, A. I., Colmenero-Hidalgo, E., Peck, V. L., Hall, I. R., Austin, W. E. N., Knutz, P. C. \& Zahn, R. 2009. Growth, dynamics and deglaciation of the last BritishIrish ice sheet: the deep-sea ice-rafted detritus record. Quaternary Science Reviews $\mathbf{2 8}$ 3066-84.

Sejrup, H. P., Nygard, A., Hall, A. M. \& Haflidason, H. 2009. Middle and Late Weichselian (Devensian) glaciation history of south-western Norway, North Sea and eastern UK. Quaternary Science Reviews 28, 370-80.

Sejrup, H. P., Hjelstuen, B. O., Nygård, A., Haflidason, H. \& Mardal, I. 2015. Late Devensian ice-marginal features in the central North Sea - processes and chronology. Boreas 44, 1-13.

Sejrup, H. P., Clark, C. D. \& Hjelstuen, B. O. 2016. Rapid ice sheet retreat triggered by ice stream debuttressing: Evidence from the North Sea. Geology 44, 355-58.

Selby, I C. 1987. Glaciated shorelines in Barra and Vatersay. Quaternary Newsletter 53, 1622.

Shackleton, N. J. 1987. Oxygen isotopes, ice volume and sea level. Quaternary Science Reviews 6, 183-90.

Shakesby, R. A. 1978. Dispersal of glacial erratics from Lennoxtown, Stirlingshire. Scottish Journal of Geology 14, 81-86.

Shaw, A.J. \& Merritt, J.W. 1981. The sand and gravel resources of the country around Biggar, Strathclyde Region: Description of 1:25,000 sheets NS93 and NT03 and parts of NS92 and NT02. Mineral Assessment Report of the Institute of Geological Sciences 95. 92pp.

Shennan, I., Bradley, S., Milne, G., Brooks, A. J., Bassett, S., Hamilton, S., Hilier, C., Hunter, A. \& Woodal, R. 2006. Relative sea level changes, glacial isostatic modelling and ice sheet reconstructions from the British Isles since the Last Glacial Maximum. Journal of Quaternary Science 21, 585-99.

Simpson, S. 1948. The glacial deposits of Tullos and Bay of Nigg, Aberdeen. Transactions of the Royal Society of Edinburgh 61, 687-687.

Simpson, S. 1955. A re-interpretation of the drifts of north-east Scotland. Transactions of the Edinburgh Geological Society 16, 189-199.

Sissons, J. B. 1963. The Perth readvance in central Scotland. Part I. Scottish Geographical Magazine 79, 151-63.

Sissons, J. B. 1964. The Perth readvance in central Scotland. Part II. Scottish Geographical Magazine 80, 28-36.

Sissons, J. B. 1967a. The Evolution of Scotland's Scenery. Edinburgh: Oliver and Boyd.

Sissons, J. B. 1967b. Glacial stages and radiocarbon dates in Scotland. Scottish Journal of Geology 3, 175-81.

Sissons, J. B. 1980. The glaciation of the Outer Hebrides. Scottish Journal of Geology 16, 8184.

Sissons, J. B. 1983. The Quaternary geomorphology of the Inner Hebrides: a review and reassessment. Proceedings of the Geologists' Association 94, 165-75. 
Sissons, J. B. \& Smith, D. E. 1965. Raised shorelines associated with the Perth Readvance in the Forth valley and their relation to glacial isostasy. Transactions of the Royal Society of Edinburgh 66, 143-68.

Small, D., Benetti, S., Dove, D., Ballantyne, C. K., Fabel, D., Clark, C. D., Gheorghiu, D. M., Newall, J. \& Xu S. 2017. Cosmogenic exposure age constraints on deglaciation and flow behaviour of a marine-based ice stream in western Scotland, 21-16 ka. Quaternary Science Reviews 167, 30-46.

Smith, D. E., Barlow, N., Bradley, S., Firth, C. R., Hall, A. M., Jordan, C. J. \& Long, D. 2018. Quaternary sea level change. Earth and Environmental Science Transactions of the Royal Society of Edinburgh https://doi.org/10.1017/S1755691017000469

Stewart, H. A., Carter, G. D. O., Dove, D., Stewart, M. A., Green, S. L., Cooper, R. M., Cotterill, C. J. \& Gafeira, J. 2019 in press. The Quaternary stratigraphy of Scotland: the offshore record. Earth and Environmental Science Transactions of the Royal Society of Edinburgh

Stewart, M. 1933. Notes on the geology of Sula Sgeir and the Flannan Islands. Geological Magazine 70, 110-16.

Stoker, M. S., Hitchen, K. \& Graham, C. C. 1993. United Kingdom Offshore Regional Report: the geology of the Hebrides and the West Shetland shelves, and adjacent deep water areas. London: HMSO.

Stoker, M. S., Bradwell, T., Howe, J. A., Wilkinson, I. P. \& Mclntyre, K. 2009. Lateglacial icecap dynamics in NW Scotland: evidence from the fjords of the Summer Isles region. Quaternary Science Reviews 28, 3161-3184.

Stoker, M. \& Bradwell, T. 2005. The Minch palaeo-ice stream, NW sector of the British-Irish ice sheet. Journal of the Geological Society, London 163, 425-28.

Stone, P., Millward, D., Young, B., Merritt, J. W., Clarke, S. M., McCormac, M. \& Lawrence, D. J. D. 2010 British Regional Geology: North England (5th Edition). Keyworth, Nottingham: British Geological Survey.

Stuiver, M. \& Grootes, P. M. 2000. GISP2 oxygen isotope ratios. Quaternary Research 53, 277-84.

Sugden, D. E. 1968. The selectivity of glacial erosion in the Cairngorm Mountains, Scotland. Transactions of the Institute of British Geographers 45, 79-92.

Sugden, D. E. 1970. Landforms of deglaciation in the Cairngorm Mountains. Transactions of the British Institute of Geographers 51, 201-19.

Sutherland, D. G. 1981. The high-level marine shell beds of Scotland and the build-up of the last Scottish ice sheet. Boreas 10, 247-54.

Sutherland, D. G. 1984. The Quaternary deposits and landforms of Scotland and the neighbouring shelves - a review. Quaternary Science Reviews 3, 157-254.

Sutherland, D. G. 1993a. Muckle Head and Selwick. In Gordon, J. E. \& Sutherland, D. G. (eds) Quaternary of Scotland. The Geological Conservation Review Series No. 6, 74-76. London: Chapman \& Hall. 
Sutherland, D. G. 1993b. North-west Highlands: introduction. In Gordon, J. E. \& Sutherland, D. G. (eds) Quaternary of Scotland. The Geological Conservation Review Series No. 6, 101-103. London: Chapman \& Hall.

Sutherland, D. G. 1993c. Teindland Quarry. In Gordon, J. E. \& Sutherland, D. G. (eds) Quaternary of Scotland. The Geological Conservation Review Series No. 6, 236-40. London: Chapman \& Hall.

Sutherland, D. G. 1993d. Castle Hill. In Gordon, J. E. \& Sutherland, D. G. (eds) Quaternary of Scotland. The Geological Conservation Review Series No. 6, 240-42. London: Chapman \& Hall.

Sutherland, D. G. 1993e. Eastern Grampian Highlands. Introduction In Gordon, J. E. \& Sutherland, D. G. (eds) Quaternary of Scotland. The Geological Conservation Review Series No. 6, 257-59. London: Chapman \& Hall.

Sutherland, D. G. 1993f. Tangy Glen. In Gordon, J. E. \& Sutherland, D. G. (eds) Quaternary of Scotland. The Geological Conservation Review Series No. 6, 310-13. London: Chapman \& Hall.

Sutherland, D. G. 1993g. Nith Bridge. In Gordon, J. E. \& Sutherland, D. G. (eds) Quaternary of Scotland. The Geological Conservation Review Series No. 6, 541-42. London: Chapman \& Hall.

Sutherland, D. G. 1993h. Port Logan. In Gordon, J. E. \& Sutherland, D. G. (eds) Quaternary of Scotland. The Geological Conservation Review Series No. 6, 593-94. London: Chapman \& Hall.

Sutherland, D. G. 1993i. Eastern Highland Boundary. Introduction. In Gordon, J. E. \& Sutherland, D. G. (eds) Quaternary of Scotland. The Geological Conservation Review Series No. 6, 477-79. London: Chapman \& Hall.

Sutherland, D. G. 1993j. Fife and Lower Tay. Introduction. In Gordon, J. E. \& Sutherland, D. G. (eds) Quaternary of Scotland. The Geological Conservation Review Series No. 6, 50911. London: Chapman \& Hall.

Sutherland, D. G. 1999. Scotland. In Bowen, D. Q. (ed.) A Revised Correlation of Quaternary Deposits in the British Isles. Special Report of the Geological Society of London No. 23, 99-114.

Sutherland, D. G., Ballantyne, C. K., Walker, M. J. C. 1982. A note on the Quaternary deposits and landforms of St Kilda. Quaternary Newsletter 37, 1-5.

Sutherland, D. G., Ballantyne, C. K., Walker, M. J. C. 1984. Late Quaternary glaciation and environmental change on St. Kilda, Scotland, and their palaeoclimatic significance. Boreas 13, 261-72.

Sutherland, D. G. \& Gordon, J. E. 1993a. The Quaternary in Scotland. In Gordon, J. E. \& Sutherland, D. G. (eds) Quaternary of Scotland. The Geological Conservation Review Series No. 6, 11-47. London: Chapman \& Hall.

Sutherland, D. G. \& Gordon, J. E. 1993b. The Shetland Islands. Introduction. In Gordon, J. E. \& Sutherland, D. G. (eds) Quaternary of Scotland. The Geological Conservation Review Series No. 6, 51-54. London: Chapman \& Hall. 
Sutherland, D. G. \& Gordon, J. E. 1993c. Inverness area. Introduction. In Gordon, J. E. \& Sutherland, D. G. (eds) Quaternary of Scotland. The Geological Conservation Review Series No. 6, 149-52. London: Chapman \& Hall.

Sutherland, D. G. \& Gordon, J. E. 1993d. North-east Scotland. Introduction. In Gordon, J. E. \& Sutherland, D. G. (eds) Quaternary of Scotland. The Geological Conservation Review Series No. 6, 213-216. London: Chapman \& Hall.

Sutherland, D. G. \& Gordon, J. E. 1993e. Western Central Lowlands. Introduction. In Gordon, J. E. \& Sutherland, D. G. (eds) Quaternary of Scotland. The Geological Conservation Review Series No. 6, 535-38. London: Chapman \& Hall.

Sutherland, D. G. \& Walker, M. J. C. 1984. A late Devensian ice-free area and possible interglacial site on the Isle of Lewis, Scotland. Nature 309, 701-703.

Synge, F. M. 1956. The glaciation of north-east Scotland. Scottish Geographical Magazine 72, 129-43.

Synge, F. M. 1963. The Quaternary succession around Aberdeen, North-East Scotland. Report on the 6th International Congress on the Quaternary, Warsaw, 1961, Vol. 3, Geomorphological Section, 353-61. Łódź: International Union for Quaternary Research.

Synge F. M. \& Stephens, N. 1966. Late- and post-glacial shorelines and ice limits in Argyll and north-east Ulster. Transactions of the Institute of British Geographers 39, 101-25.

Tait, D. 1912. On a large glacially transported mass of Lower Cretaceous rock at Leavad in the county of Caithness. Transactions of the Geological Society of Edinburgh 10, 1-9.

Thierens, M., Pirlet, H., Colin, C., Latruwe, K., Vanhaecke, F., Lee, J. R., Stuut, J. B., Titschack, J., Huvenne, V. A. I., Dorschel, B., Wheeler, A. J. \& Henriet, J. P. 2012. Ice-rafting from the British-Irish ice sheet since the earliest Pleistocene (2.6 million years ago): implications for long-term mid-latitudinal ice-sheet growth in the North Atlantic region. Quaternary Science Reviews 44, 229-40.

Thomas, G.S.P. \& Montague, E. 1997. The morphology, stratigraphy and sedimentology of the Carstairs Esker, Scotland, UK. Quaternary Science Reviews 16, 661-74.

Toucanne, S., Soulet, G., Freslon, N., Silva Jacinto, R., Dennielou, B., Zaragosi, S., Eynaud, F., Bourillet, J.-F. \& Bayon, G. 2015. Millennial-scale fluctuations of the European Ice Sheet at the end of the last glacial, and their potential impact on global climate. Quaternary Science Reviews 123, 113-33.

Trotter, F. M. 1929. The glaciation of the Eastern Edenside, the Alston Block, and the Carlisle Plain. Quarterly Journal of the Geological Society of London 85, 549-612.

Trotter, F. M. \& Hollingworth, S. E. 1932a. The glacial sequence in the North of England. Geological Magazine 69, 374-80.

Trotter, F. M. \& Hollingworth, S. E. 1932b. The geology of the Brampton district. Memoir of the Geological Survey of Great Britain, Sheet 18 (England and Wales). London: HMSO.

Trotter, F.M., Hollingworth, S.E., Eastwood, T. \& Rose, W.C.C. 1937. Gosforth District. Geological Survey Memoir, England and Wales, Sheet 37.

Turner, A. J., Woodward, J., Dunning, S. A., Shine, A. J., Stokes, C. R. \& Ò Cofaigh, C. 2012. Geophysical Surveys of the sediments of Loch Ness, Scotland: implications for the 
deglaciation of the Moray Firth Ice Stream, British-Irish Ice Sheet. Journal of Quaternary Science 27, 221-32.

Valen, V., Larsen, E. \& Mangerud, J. 1995. High-resolution paleomagnetic correlation of Middle Weichselian ice-dammed lake sediments in two coastal caves, western Norway. Boreas 24, 141-53.

Valen, V., Mangerud, J., Larsen, E. \& Hufthammer, A. K. 1996. Sedimentology and stratigraphy in the cave Hamnsundhelleren, western Norway. Journal of Quaternary Science 11, 185-201.

von Weymarn, J. 1979. A new concept of glaciation in Lewis and Harris, Outer Hebrides. Proceedings of the Royal Society of Edinburgh 77B, 97-105.

von Weymarn, J. \& Edwards, K. J. 1973. Interstadial site on the island of Lewis, Scotland. Nature 246, 473-74.

Wager, L. 1953. The extent of glaciation in the island of St. Kilda. Geological Magazine 90, $177-81$.

Walker, M. J. C. 1984. A pollen diagram from St Kilda, Outer Hebrides, Scotland. New Phytologist 97, 99-113.

Walker, M. J. C., Merritt, J. W., Auton, C. A., Coope, G. R., Field, M. H., Heijnis, H. \& Taylor, B. J. 1992. Allt Odhar and Dalcharn: two pre-Late Devensian (Late Weichselian) sites in northern Scotland. Journal of Quaternary Science 7, 69-86.

Whittington, G. 1990. The Dalcharn interglacial site, near Cawdor, Nairnshire. Results of pollen analysis on the Dalcharn Biogenic member. In Auton, C. A., Firth, C. R. \& Merritt, J. W. (eds) Beauly to Nairn: Field Guide, 74-96. Cambridge: Quaternary Research Association.

Whittington, G. 1994. Bruckenthalia spiculifolia (Salisb.) Reichenb. (Ericaceae) in the Late Quaternary of Western Europe. Quaternary Science Reviews 13, 761-68.

Whittington, G., Hall, A.M. \& Jarvis, J. 1993. A pre-Late Devensian pollen site at Camp Fauld, Buchan, north-east Scotland. New Phytologist 125, 867-74.

Whittington, G., Connell, E. R., Coope, G. R., Edwards, K. J., Hall, A. M., Hulme, P. D. \& Jarvis, J. 1998. Devensian organic interstadial deposits and glacier extent in Buchan, Scotland. Journal of Quaternary Science 13, 309-24.

Whittington, G. \& Hall, A. M. 2002. The Tolsta Interstadial, Scotland: correlation with D-O cycles GI-8 to GI-5? Quaternary Science Reviews 21, 901-15.

Wilson, G. V., Edwards, W., Knox, J., Jones, R. C. B. \& Stephens, J. V. 1935. The Geology of the Orkneys. Memoir of the Geological Survey of Scotland. Edinburgh: HMSO.

Young, J. A. T. 1974. Ice wastage in the Glenmore, upper Spey Valley, Inverness-shire. Scottish Journal of Geology 10, 147-57.

Young, J. A. T. 1975a. Ice wastage in Glen Feshie, Inverness-shire. Scottish Geographical Magazine 91, 91-101.

Young, J. A. T. 1975b. A re-interpretation of the deglaciation of Abernethy Forest, Invernessshire. Scottish Journal of Geology 11, 193-205. 
Young, J. A. T. 1977a. Glacial geomorphology of the Aviemore-Loch Garten area, Strathspey, Inverness-shire. Geography 62, 25-34.

Young, J. A. T. 1977b. Glacial geomorphology of the Dulnain Valley, Inverness-shire. Scottish Journal of Geology 13, 59-74.

Young, J A T. 1978. The Landforms of Upper Strathspey. Scottish Geographical Magazine 94, 76-94.

\section{Late Pleistocene Figure and Table captions}

\section{Figures}

1. Summary of Late Quaternary chronostratigraphic stages (Great Britain) and their correlation with Marine Isotope Stages (MIS) (after Lisiecki \& Raymo 2005; Bradwell et al. 2008a; Otvos 2015). The approximate timings of the local Last Glacial Maximum (LLGM) (c. 30-27 ka) (Ballantyne \& Small 2018) and global LGM (23-21 ka) (Hughes et al. 2016) are shown. Note that some terrestrial stage boundaries are not coincident with MIS boundaries. DS: Dimlington Stadial. WI: Windermere Interstadial. LLS: Loch Lomond Stadial.

2. Greenland oxygen isotope record from the NGRIP ice core (NGRIP Members 2004) and the main event stratigraphy (Rasmussen et al. 2014). The age scale is based on the GIC05 age model. GI: Greenland Interstadials; GS: Greenland Stadials. MIS boundaries are based on Lisiecki \& Raymo (2005), Railsback et al. (2015) and Otvos (2015). The indicative presence of glaciers in Scotland is adapted from Clapperton (1997): MIF: mountain icefields; IS: Ice sheets; MIC: mountain ice caps; MG: small mountain glaciers.

3. Distribution of glacigenic subgroups $(A)$ and superficial till units $(B)$ (modified from McMillan et al. 2011). C: Cairngorms. G: Gaick. R: Rannoch Moor.

4. Evidence for the pattern of ice flow on Shetland (modified from Hall 2013). A. Directions of glacial erratic carry. B. Measurements of striae, excluding disputed early records (from Peach \& Horne 1879). C. Palynomorph records for till matrix at key sites (J.B. Riding, pers. comm. 2016) [Sample sites: 1. Vidlin Voe; 2. Sand Voe; 3. Colla Firth; 4. South Nesting; 5. Salt Wick; 6. Wick of Collaster; 7. Norwick; 8. Westing; 9. The Bugg; 10. Sand Wick; 11-13. Breiwick; 14. Little Bixter; 15. Sand of Hayes; 16. Da Ristie Nessies]. D. Ice flow directions from roches moutonnées.

1. The stratigraphy at Fugla Ness, Shetland (modified from Hall et al. 2002).

6. The stratigraphy at Sel Ayre, Shetland (modified from Hall et al. 1993a).

7. Till stratigraphy (A) and striae (B) in Caithness and Orkney (modified from Hall \& Riding 2016 and Hall et al. 2016a). 1. Unconformity or disconformity within a till unit. 2. Sand or gravel layer. 3. Western limit of the Forse Till derived from the inner Moray Firth in Caithness and Sutherland.

8. Sections of stacked tills on Orkney (modified from Hall et al. 2016a). 
9. Records of glacial erratics in Caithness and Orkney (modified from Hall \& Riding 2016 and Hall et al. 2016a).

10. Domains and transport directions for glacial erratics recorded on Caithness, Orkney and Shetland. WG Witch Ground. Shetland rocks (blue arrows) are confined to Shetland, including Fair Isle, and the surrounding shelf. Scandinavian erratics (dark green arrows) occur on N Orkney, Fair Isle and at one location in southernmost Shetland. Carboniferous limestone, sandstone and volcanic clasts from the Firth of Forth and eastern Scotland (pale green arrows) are recorded only from Fair Isle and N Orkney. Igneous and metamorphic erratics from NE Scotland (orange arrows) occur along the shores of the Pentland Firth, in N Orkney and on Fair Isle. Erratics from the Northern Highlands (red arrows) are recorded as far north as N Ronaldsay. Jurassic and Lower Cretaceous rocks and fossils from the inner Moray Firth (purple arrows) occur in Caithness and N Orkney. Erratics of Late Cretaceous chalk and flint (yellow arrows and outcrop) are found $\mathrm{N}$ of Wick and along the Pentland Firth, locally in high concentrations, and in N Orkney. Flint is found in tills on Fair Isle, but may be derived originally from sources in the Danish sector of the North Sea.

11. The stratigraphy at Wester Clett, Caithness (from Hall et al. 2011). See Table 4 for abbreviations.

12. Time frame and glaciation curve for the main events of the last ice sheet on the AtlanticNorth Sea Divide. GISP2 ice core data from Stuiver \& Grootes (2000); binge-purge cycles and ice extent from Hubbard et al. (2009); till stratigraphy from Hall \& Riding (2016) and Hall et al. (2016a). DT: Dunbeath Till; DHT: Drumhollistan Till; FT: Forse Till; PST: Portskerra Till; QT: Quendale Till; STT: Scara Taing Till; WT: Wick Till.

13 Physiography of the NW Highlands and Outer Hebrides showing the position of the former Minch Ice Stream (modified after Bradwell \& Stoker 2015). Hill-shaded surface model built from Intermap Technologies NEXTMap Britain elevation data.

14. The Galson Raised Beach on NW Lewis. A. South Galson. Undisturbed storm beach gravel of likely MIS $5 e$ age at $\sim 5 \mathrm{~m}$ OD overlain by cryoturbated gravel with erect clasts and layers of gravel-rich diamicton (Lewis Till) deposited by local ice. B. Eoropie. A small raft of Galson Raised Beach gravel within brown mud-rich diamicton (Port Beag Till) deposited by the Minch Ice Stream.

15. Generalized stratigraphy at Tolsta Head on NW Lewis (modified from Gordon \& Sutherland 1993b).

16. Hirta, St Kilda, looking SW to Dùn, showing tor landforms mantled by thick periglacial slope deposits.

17. Transport paths of some indicator erratics across the inner Moray Firth (after Mackie 1905; Sissons 1967a; Fletcher et al. 1996; Merritt et al. 2017a). Hill-shaded surface model built from Intermap Technologies NEXTMap Britain elevation data.

18. Megagrooves on the western flank of Suidhe Ghuirmain in the Endrick valley, $\mathrm{N}$ of the Great Glen, looking SE. Inset: rock drumlin associated with the megagrooves. Ice flowed towards the Moray Firth, to the NE (left). See preceding figure for location.

19. Summary logs of sections recorded at Dalcharn (modified after Walker et al. 1992). 
20. The Allt Odhar section showing details of the Odhar Peat Formation and the position of the sampling points for pollen, insect and plant macrofossil remains (modified from Walker et al. 1992). The terminology follows McMillan et al. (2011a).

21. Transport paths of some indicator erratics in NE Scotland (after Read 1923; Bremner 1928; Synge 1956; Sissons 1967a; Merritt et al. 2003). Hill-shaded surface model built from Intermap Technologies NEXTMap Britain elevation data.

22. Summary logs of sections recorded at the Howe of Byth Quarry, SW of Fraserburgh (modified after Hall \& Connell 2000).

23. Conceptual glacial reconstructions depicting stages in the evolution of the NE quadrant of the last BIIS (modified after Merritt et al. 2017a). (A) Reconstruction similar to that of Boulton et al. (1985, fig. 10) (stage 1); (B) LLGM (stage 2); (C) Considerable thinning and glacial reorganisation during stages 3 and 4; (D) Re-expansion following possible marine ingression into the Witch Ground basin during stage 5, followed by probable coalescence of BIIS and the Norwegian Channel Ice Stream at the Tampen Ridge (see cartoon 6 for limits); (E) Marine ingression to Lunan Bay during Stage 7; (F) Stages 8-12 and other limits after Clark et al. (2012, fig. 12 and 13). Red hexagons show the centre of the Witch Ground basin. Ice divides shown by thick black lines with open diamonds; single filled ticks denote ice divide receding by ice stream headward scavenging.

24. Generalised stratigraphy recorded at Boyne Quarry in 2014, E of Portsoy: encircled letters refer to units described by Peacock \& Merritt (2000a).

25. Subglacially streamlined features and ice marginal glacial drainage channels around Boyne Quarry and the Howe of Byth sites (modified after Merritt et al. 2017a). Flowsets (fs) after Hughes et al. 2014. Hill-shaded surface model built from Intermap Technologies NEXTMap Britain elevation data.

26. Reconstruction of ice-free enclaves and proglacial lakes in Buchan (modified after Merritt et al. 2017): (a) confluence between ice lobes during stage 5, creation of $80 \mathrm{~m}$ Glacial Lake Ugie (GLU) followed by the 'Logie-Buchan Readvance' and creation of $50 \mathrm{~m}$ GLU during stage 6; (b) decay of the Logie-Buchan ice lobe, further retreat of East Grampian ice followed by re-advance of Moray Firth ice during stages 7-9; (c) St. Fergus Readvance and subsequent ponding during glacial retreat along the Banffshire coast during stages 10-11.

27. Growth and decay of the last BIIS over western Scotland, the North Channel and NE Ireland (modified after Finlayson et al. 2014). Diagonal shading denotes probable cold-based ice. Dashed lines denote ice divides. Age estimates modified in respect of the recently published age of the Scottish Readvance determined by Chiverrell et al. (2018). Hill-shaded surface model built from Intermap Technologies NEXTMap Britain elevation data.

28. Simplified glacial lithostratigraphy for the Clyde and Ayrshire basins (after McMillan et al. 2011a). Fm: formation; Mbr: member; LLS: Loch Lomond Stadial; LI: Lateglacial Interstadial. Greenland Ice Core GICC05 Chronology events after Lowe et al. (2008b); GS: Greenland Stadial; GI: Greenland Interstadial. 
29. Reconstructed stages of glaciation in the West Central Lowlands (modified from Finlayson 2012). Clyde basin outlined in red. AF: Afton Lodge; CE: Carstairs Eskers; G: Grangemouth; GG: Glengavel; FF: Firth of Forth. Hill-shaded surface model built from Intermap Technologies NEXTMap Britain elevation data.

30. Glacial geomorphology and geology of the Clyde and Ayrshire basins (modified from Finlayson et al. 2010). Erratic limits are from Eyles et al. (1949) and glacial striations from Paterson et al. (1998).

31. Reconstructed stages of glaciation around the Solway Firth (modified from Livingstone et al. 2012). Dashed-dotted lines refer to ice divides (with the thick dotted lines indicating possible ice-saddles) and the arrows indicate ice flow vectors (dotted arrows indicate alternative ice flow scenarios). Hill-shaded surface model built from Intermap Technologies NEXTMap Britain elevation data.

\section{Tables}

1. Summary details of the groups within the Great Britain Superficial Deposits Supergroup represented in Scotland (from McMillan et al. 2011a).

2. Summary of events in the Shetland Islands. B: glacial 'binge'; C: cold-periglacial; I: Interglacial; IS: Interstadial; P: glacial 'purge'; R: glacial readjustment.

3. Summary of events in Caithness and on the islands of Orkney (see Table 2 for abbreviations).

4. Stratigraphy at Wester Clett, Caithness (after Hall et al. 2011).

5. Summary of events in the Outer Hebrides (see Table 2 for abbreviations).

6. Summary of events in the NW Highlands (see Table 2 for abbreviations).

7. Summary of events in the Central Highlands (see Table 2 for abbreviations).

8. Summary of events around Inverness and Moray (see Table 2 for abbreviations). Estimated ages after Merritt et al. (2017a).

9. The lithostratigraphy in the vicinity of Teindland Quarry, near Elgin.

10. Summary of events in NE Scotland. See Table 2 for abbreviations. Stages and estimated ages after Merritt et al. (2017a).

11. The lithostratigraphy at Kirkhill and Leys quarries relating to the last glacial-interglacial cycle. Note: due to the position of the sites in eastern Buchan, and the accommodation space available in channels/basins, this complex stratigraphy does not exceed $2.5-3.0 \mathrm{~m}$ in total thickness.

12. Summary of events in Argyll. See Table 2 for abbreviations. Stages and ages modified after Finlayson et al. (2014) and Chiverrell et al. (2018). 
13. Summary of events in western central Scotland and Ayrshire. See Table 2 for abbreviations. Stages and estimated ages modified after Finlayson et al. (2010) and Finlayson (2012).

14. Summary of events in the Solway Lowlands. See Table 2 for abbreviations. Stages and estimated ages after Livingstone et al. (2012) and Chiverrell et al. (2018). 


\section{Late Pleistocene Tables}

Table 1. Summary details of the groups within the Great Britain Superficial Deposits Supergroup represented in Scotland (from McMillan et al. 2011a). MIS = Marine Isotope Stage.

\begin{tabular}{|c|c|c|c|}
\hline $\begin{array}{l}\text { Group } \\
\text { name }\end{array}$ & Genesis & Lithologies and textures & Age \\
\hline $\begin{array}{l}\text { Britannia } \\
\text { Catchments } \\
\text { Group }\end{array}$ & $\begin{array}{l}\text { Fluvial, } \\
\text { organic } \\
\text { and mass } \\
\text { movement }\end{array}$ & $\begin{array}{l}\text { Clastic deposits; boulder, } \\
\text { gravel, sand, silt and clay } \\
\text { grades; periglacial slope } \\
\text { deposits/gelifluctate/'head' }\end{array}$ & $\begin{array}{l}\text { Holocene to } \\
\text { pre-Anglian, } \\
\text { MIS 1-pre-12 }\end{array}$ \\
\hline $\begin{array}{l}\text { Caledonia } \\
\text { Glacigenic } \\
\text { Group }\end{array}$ & Glacigenic & $\begin{array}{l}\text { Clastic deposits; boulder, } \\
\text { gravel, sand, silt and clay } \\
\text { grades; diamictons } \\
\text { (including till) }\end{array}$ & $\begin{array}{l}\text { Devensian } \\
\text { (Weichselian), } \\
\text { MIS 2-5d }\end{array}$ \\
\hline $\begin{array}{l}\text { Albion } \\
\text { Glacigenic } \\
\text { Group }\end{array}$ & Glacigenic & $\begin{array}{l}\text { Clastic deposits; boulder, } \\
\text { gravel, sand, silt and clay } \\
\text { grades; diamictons } \\
\text { (including till) }\end{array}$ & $\begin{array}{l}\text { pre- } \\
\text { Devensian } \\
\text { (pre- } \\
\text { Weichselian), } \\
\text { pre-MIS 5e }\end{array}$ \\
\hline $\begin{array}{l}\text { Residual } \\
\text { Deposits } \\
\text { Group }\end{array}$ & $\begin{array}{l}\text { Residual } \\
\text { and } \\
\text { weathering } \\
\text { products }\end{array}$ & $\begin{array}{l}\text { Clastic deposits; gravel, } \\
\text { sand, silt and clay grades }\end{array}$ & $\begin{array}{l}\text { Tertiary to } \\
\text { Early } \\
\text { Pleistocene }\end{array}$ \\
\hline $\begin{array}{l}\text { British } \\
\text { Coastal } \\
\text { Deposits } \\
\text { Group }\end{array}$ & $\begin{array}{l}\text { Marine } \\
\text { and coastal }\end{array}$ & $\begin{array}{l}\text { Clastic deposits; gravel, } \\
\text { sand, silt, and clay grades }\end{array}$ & $\begin{array}{l}\text { Holocene to } \\
\text { pre-Anglian, } \\
\text { MIS 1-pre-12 }\end{array}$ \\
\hline
\end{tabular}

Table 2. Summary of events in the Shetland Islands. B: glacial 'binge'; C: cold-periglacial; I: Interglacial; IS: Interstadial; P: glacial 'purge'; R: glacial readjustment.

\begin{tabular}{|c|c|c|}
\hline Age & \multicolumn{2}{|l|}{ Events, palaeo-environments, important sites \& units } \\
\hline MIS 5e & Formation of the Fugla Ness Peat under a warm, humid climate. & $\mathbf{I}$ \\
\hline MIS 5d & $\begin{array}{l}\text { Climatic deterioration with development of periglacial slope deposits } \\
\text { at Fugla Ness and Sel Ayre during MIS } 5 \mathrm{~d} \text {. }\end{array}$ & C \\
\hline MIS 5c & $\begin{array}{l}\text { Climatic amelioration and formation of the Sel Ayre Organic Sand \& } \\
\text { Gravel. }\end{array}$ & IS \\
\hline MIS 5a-b & $\begin{array}{l}\text { Climatic deterioration and renewed periglacial activity, with multiple } \\
\text { phases of periglacial deposition at Sel Ayre. }\end{array}$ & C/IS \\
\hline MIS 4 & \multirow[t]{4}{*}{ No deposits firmly attributable to these intervals. } & \\
\hline MIS 3 & & \\
\hline LLGM & & \\
\hline GI-2 & & \\
\hline LGM & $\begin{array}{l}\text { Development of a large ice cap over Shetland laying down the Burrier } \\
\text { Wick Till. Ice confluent with the FIS along the western edge of the } \\
\text { Norwegian Channel and extending towards the shelf edge. }\end{array}$ & B \\
\hline c. $15 \mathrm{ka}$ & Active retreat of an independent Shetland ice cap. & $\mathbf{P}$ \\
\hline
\end{tabular}


Table 3. Summary of events in Caithness and on the islands of Orkney (see Table 2 for abbreviations).

\begin{tabular}{|c|c|c|}
\hline Age & \multicolumn{2}{|l|}{ Events, palaeo-environments, important sites \& units } \\
\hline MIS 5e & $\begin{array}{l}\text { Raised rock platforms in Caithness (till covered) and on Hoy beneath } \\
\text { raised beach deposits (Muckle Head Gravel). }\end{array}$ & 1 \\
\hline MIS 5a-d & Periglacial deposits on Hoy resting on Muckle Head Gravel. & C \\
\hline MIS 4 & \multirow[t]{2}{*}{ No deposits are known from these intervals. } & \\
\hline MIS 3 & & \\
\hline LLGM & $\begin{array}{l}\text { Ice advances NW across Orkney depositing the Digger Till. Advance of } \\
\text { NW Highland ice to Reay and onto the plain of Caithness laying down } \\
\text { the Portskerra Till. }\end{array}$ & B \\
\hline GI-3 & Withdrawal of NW Highland ice from Caithness & $\mathbf{P}$ \\
\hline $\begin{array}{l}\text { GI-3 to GI- } \\
2\end{array}$ & $\begin{array}{l}\text { Three advances of Moray Firth ice into Caithness depositing the } \\
\text { Drumhollistan, Eastern Gully and Wester Clett tills at Wester Clett. }\end{array}$ & P/B \\
\hline LGM & $\begin{array}{l}\text { Major expansion of ice from the Moray Firth across Caithness and } \\
\text { Orkney reaching the shelf edge, depositing the Scara Taing Till in } \\
\text { Orkney and the Forse Till in Caithness. }\end{array}$ & B \\
\hline $\begin{array}{l}\sim 18-\sim 15 \\
k a\end{array}$ & Partial deglaciation of Orkney and Caithness. & $\mathbf{P}$ \\
\hline 15 ka & $\begin{array}{l}\text { Final readvance of ice NW across Orkney and Caithness laying down } \\
\text { the Quendale Till on Orkney and the Wick Till in Caithness. }\end{array}$ & B \\
\hline $15-14 \mathrm{ka}$ & $\begin{array}{l}\text { Ice retreat towards the Inner Moray Firth interrupted by local } \\
\text { readvances towards Thurso and Wick and by final stillstands at Strath } \\
\text { More (Dalemore) and Berriedale. }\end{array}$ & $\mathbf{P}$ \\
\hline
\end{tabular}

Table 4. Stratigraphy at Wester Clett, Caithness (after Hall et al. 2011).

\begin{tabular}{|c|c|c|c|c|c|c|c|}
\hline Group & $\begin{array}{l}\text { Sub- } \\
\text { Group }\end{array}$ & Formation & Member & $\begin{array}{l}\text { Beds (identified at } \\
\text { Wester Clett }\end{array}$ & Member & Formation & $\begin{array}{l}\text { Sub- } \\
\text { Group }\end{array}$ \\
\hline \multirow{6}{*}{ 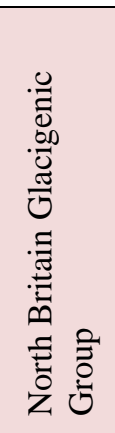 } & \multirow{6}{*}{ 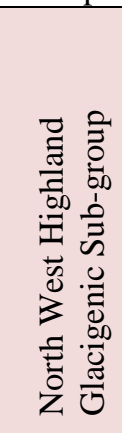 } & \multirow{5}{*}{$\begin{array}{l}\text { Reay Burn } \\
\text { Till }\end{array}$} & $\begin{array}{l}\text { Thormaid } \\
\text { Till }\end{array}$ & $\begin{array}{l}\text { Cnoc a' Mhàil Till } \\
\text { (CNAMT) }\end{array}$ & \multirow{6}{*}{$\begin{array}{c}\text { Forse } \\
\text { Till }\end{array}$} & \multirow{6}{*}{$\begin{array}{l}\text { Reisgill } \\
\text { Burn Till }\end{array}$} & \multirow{6}{*}{ 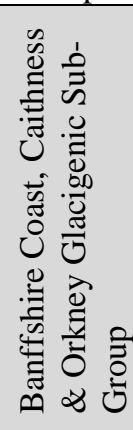 } \\
\hline & & & \multirow{4}{*}{$\begin{array}{l}\text { Broubster } \\
\text { Till }\end{array}$} & $\begin{array}{l}\text { Wester Clett Till } \\
(\boldsymbol{W C T})\end{array}$ & & & \\
\hline & & & & Eastern Gulley Till (EGT) & & & \\
\hline & & & & $\begin{array}{l}\text { Geodh' Easgaidh } \\
\text { Gravel (GEG) }\end{array}$ & & & \\
\hline & & & & Drumhollistan Till (DHT) & & & \\
\hline & & $\begin{array}{l}\text { Dunbeath } \\
\text { Till }\end{array}$ & $\begin{array}{l}\text { Portskerra } \\
\text { Till }\end{array}$ & Stack Till(PST) & & & \\
\hline
\end{tabular}


Table 5. Summary of events in the Outer Hebrides (see Table 2 for abbreviations).

\begin{tabular}{|l|l|l|}
\hline Age & Events, palaeo-environments, important sites \& units \\
\hline MIS 5e & $\begin{array}{l}\text { Re-occupation and weathering of shore platforms at 4-10 m OD } \\
\text { (excluding St Kilda). Creation of the Galson Raised Beach. Marine } \\
\text { transgression and storm beach progradation on Lewis, Barra and } \\
\text { Vatersay (Selby 1987). }\end{array}$ & I \\
\hline MIS 5a-d & Establishment of interstadial grassland at Sgarbh Sgeir. & C/IS \\
\hline MIS 4 & Cryoturbation of the Galson Raised Beach. & C \\
\hline MIS 3 & $\begin{array}{l}\text { Establishment of grassland at Tolsta Head and on St Kilda during the } \\
\text { 'Tolsta Interstadial'. Marine and glaciomarine sedimentation in The } \\
\text { Minch to provide shell fragments in later glacial deposits }\end{array}$ & C/IS \\
\hline LLGM & $\begin{array}{l}\text { Growth of a local ice cap between Lewis and Barra, with episodic ice } \\
\text { stream development in the Sounds of Harris and Barra. Deposition } \\
\text { of the Lewis Till. Cirque glaciers on St Kilda deposit the Village Bay } \\
\text { Till. }\end{array}$ & B \\
\hline LGM & $\begin{array}{l}\text { Incursion of the Minch Ice Stream into NE Lewis to deposit the Port } \\
\text { Beag Till. }\end{array}$ & P \\
\hline $\begin{array}{l}\text { 18.9-17.1 } \\
\text { katreat of ice into the mountains of Harris. Deglaciation of Mingulay } \\
\text { and Barra. }\end{array}$ & $\mathbf{P}$ \\
\hline
\end{tabular}

Table 6. Summary of events in the NW Highlands (see Table 2 for abbreviations).

\begin{tabular}{|l|l|l|}
\hline Age & Events, palaeoenvironments, important sites \& units \\
\hline MIS 5e & $\begin{array}{l}\text { Speleothem growth in the Allt nan Uamh caves indicate fully ice-free } \\
\text { conditions. }\end{array}$ & I \\
\hline MIS 5a-d & $\begin{array}{l}\text { Intermittent growth of speleothems in the Allt nan Uamh caves } \\
\text { indicate mainly ice-free conditions, especially during MIS 5a-b. }\end{array}$ & C/IS \\
\hline MIS 4 & $\begin{array}{l}\text { Intermittent growth of speleothems in the Allt nan Uamh caves } \\
\text { indicate mainly ice-free conditions. }\end{array}$ & C/IS \\
\hline MIS 3 & $\begin{array}{l}\text { Intermittent speleothem growth in the Traligill caves and radiocarbon } \\
\text { dates on reindeer antlers and brown bear bones from the Allt nan } \\
\text { Uamh caves indicate periods of ice-free conditions. }\end{array}$ & C/IS \\
\hline LLGM? & $\begin{array}{l}\text { Speleothem growth in the Allt nan Uamh caves and radiocarbon dates } \\
\text { on reindeer antlers and brown bear bones from the Allt nan Uamh } \\
\text { caves suggest ice-free conditions 36-26 ka. }\end{array}$ & C/IS \\
\hline LGM & $\begin{array}{l}\text { Westward expansion of the last ice sheet with ice streams flowing } \\
\text { offshore (e.g., MPIS). Deposition of the Loch Broom Till. }\end{array}$ & B \\
\hline $\begin{array}{l}\text { c.21-15.3 } \\
\text { ka }\end{array}$ & $\begin{array}{l}\text { Partial deglaciation accompanied by deposition of moraines and } \\
\text { outwash of the Assynt Glacigenic Formation. }\end{array}$ & P \\
\hline 15.3 ka & Wester Ross Readvance. & B \\
\hline $\begin{array}{l}\text { 15.3-14.7 } \\
\text { ka }\end{array}$ & $\begin{array}{l}\text { Renewed deglaciation interrupted by local readvances and deposition } \\
\text { of moraines, outwash and deltaic deposits. }\end{array}$ & P \\
\hline
\end{tabular}


Table 7. Summary of events in the Central Highlands (see Table 2 for abbreviations).

\begin{tabular}{|l|l|l|}
\hline Age & Events, palaeoenvironments, important sites \& units & \\
\hline MIS 5e & No reported evidence. & B \\
\hline MIS 5a-d & No reported evidence. \\
\hline MIS 4 & $\begin{array}{l}\text { Possible deposition of the Pattack Till during an Early Devensian } \\
\text { glaciation. }\end{array}$ & B \\
\hline MIS 3 & No reported evidence. & B \\
\hline LLGM & $\begin{array}{l}\text { Ice advanced from W ponding lakes into which the Ceardaich Sand \& } \\
\text { Gravel and Linn of Pattack Silt were deposited as fan-deltas. }\end{array}$ & $\begin{array}{l}\text { Most of district excepting the Cairgorms and eastern Gaick engulfed } \\
\text { by ice from W depositing the Ardverikie Till. }\end{array}$ \\
\hline LGM & $\begin{array}{l}\text { Ice streamed N from upper Strathspey across the Spey-Findhorn } \\
\text { divide through a narrow corridor centred on Lochindorb (Fig. 17). }\end{array}$ & P \\
\hline 18-15 ka & $\begin{array}{l}\text { A huge outlet glacier becomes established in upper Strathspey when } \\
\text { ice could no longer flow across the Spey-Findhorn divide. }\end{array}$ & P \\
\hline 15.1 ka & $\begin{array}{l}\text { Local readvance of Strathspey glacier into Rothiemurchus followed } \\
\text { by active retreat towards Loch Etteridge. }\end{array}$ & B \\
\hline
\end{tabular}

Table 8. Summary of events around Inverness and Moray (see Table 2 for abbreviations). Estimated ages after Merritt et al. (2017a).

\begin{tabular}{|c|c|c|}
\hline Age & Events, palaeo-environments, important sites \& units & \\
\hline MIS 5e & Formation of palaeosols at Dalcharn and Teindland & IG \\
\hline MIS 5a-d & Accumulation of the Odhar Peat at Moy, probably during MIS 5c. & C/IS \\
\hline MIS 4 & $\begin{array}{l}\text { Possible deposition of the Woodside Diamicton at Teindland and } \\
\text { concealed sandy tills around Dalcharn and Moy during an Early } \\
\text { Devensian glaciation. }\end{array}$ & B \\
\hline MIS 3 & $\begin{array}{l}\text { Possible accumulation of the Odhar Peat early in MIS 3. Deposition } \\
\text { of the Clava Shelly Clay in the Loch Ness basin. }\end{array}$ & C/IS \\
\hline LLGM & $\begin{array}{l}\text { ESE flow across the Great Glen and inner Moray Firth lays down } \\
\text { the sandy Athais Till. Dislocation and transport of rafts to Clava. }\end{array}$ & B \\
\hline 24 ka? & Ice flow to E deposits the Cantray Till at Dalcharn (Fig. 19). & $\mathbf{R}$ \\
\hline $23 \mathrm{ka?}$ & $\begin{array}{l}\text { Northward flow across the Spey-Findhorn divide lays down the } \\
\text { Ruallan Till at Dalcharn (Fig.19). }\end{array}$ & $\mathbf{P}$ \\
\hline LGM & $\begin{array}{l}\text { Long period of glaciation laying down Beinn an Uain Till and } \\
\text { Finglack Till in part. }\end{array}$ & B \\
\hline \multirow[t]{2}{*}{ 16-15 ka } & $\begin{array}{l}\text { Partial deglaciation of the Middle Findhorn and establishment of } \\
\text { the Moray Firth Ice Stream (MFIS) that lays down the Finglack Till } \\
\text { around the inner Moray Firth following the Elgin Oscillation. }\end{array}$ & $\mathbf{P}$ \\
\hline & $\begin{array}{l}\text { Minor oscillations of the MFIC during retreat. Deposition of the } \\
\text { glaciomarine Ardersier Silts at } \sim 30 \mathrm{~m} \text { OD. }\end{array}$ & $\mathbf{P}$ \\
\hline \multirow[t]{2}{*}{$\begin{array}{l}15-14.7 \\
\text { ka }\end{array}$} & $\begin{array}{l}\text { Major readvance of the MFIS at Ardersier lays down the Baddock } \\
\text { Till on top of the Ardersier Silts. }\end{array}$ & $R / B$ \\
\hline & Stillstand at Alturlie and deposition of the Bothyhill Gravels. & $\mathbf{R}$ \\
\hline
\end{tabular}


Table 9. The lithostratigraphy in the vicinity of Teindland Quarry, near Elgin.

\begin{tabular}{|r|l|ll|c|}
\hline Unit & Formal name (Merritt et al. 2003) & Original name (Hall et al. 1995a) & $\begin{array}{l}\text { Depositional } \\
\text { environment }\end{array}$ & MIS \\
\hline 9 & Waterworks Till Formation & Glacial & 2 \\
8 & Tofthead Till Formation & Glacial & 2 \\
7 & Altonside Till Formation & Glacial & $? 2$ \\
6 & Woodside Diamicton Formation & Teindland Till & Glacial & $? 4$ \\
5 & Badentinian Sand Bed & Teindland Upper Sand & Slopewash & $5 a / 4$ \\
4 & Teindland Palaeosol Bed & Teindland Buried Soil & Interglacial soil & $5 e$ \\
3 & Orbliston Sand Bed & Teindland Lower Sand & Glaciofluvial & 6 \\
2 & Deanshillock Gravel Formation & Teindland Gravel & 6 \\
1 & Red Burn Till Formation & & Glacial & 6 \\
\hline
\end{tabular}

Table 10. Summary of events in NE Scotland. See Table 2 for abbreviations. Stages and estimated ages after Merritt et al. (2017a).

\begin{tabular}{|c|c|c|c|}
\hline \multirow[t]{2}{*}{ Stage } & \multirow{2}{*}{$\begin{array}{l}\text { Age } \\
\text { MIS } 5 e\end{array}$} & \multicolumn{2}{|l|}{ Events, palaeo-environments, important sites and units } \\
\hline & & Formation of palaeosols at Kirkhill and Leys. & $\mathbf{I}$ \\
\hline & MIS 5a-d & $\begin{array}{l}\text { Cold \& cool stages represented at the Kirkhill, Camp Fauld, Crossbrae } \\
\& \text { Burn of Benholm sites. }\end{array}$ & C/IS \\
\hline & MIS 4 & $\begin{array}{l}\text { Periglacial phenomena at Kirkhill \& Leys. ESE flow from shelf edge } \\
\text { parallel ice sheet with outwash at Oldmill \& Nigg Bay? }\end{array}$ & C/B \\
\hline 1 & MIS 3 & $\begin{array}{l}\text { No known organic deposits, but early advance from NW deposited } \\
\text { the Howe of Byth Gravel? }\end{array}$ & C/IS \\
\hline 2 & $\begin{array}{c}\text { 32-24 ka } \\
\text { LLGM }\end{array}$ & $\begin{array}{l}\text { SE flow of ice from across the Moray Firth towards Aberdeen } \\
\text { depositing Whitehills Glacigenic Formation at Boyne Quarry, } \\
\text { Gardenstown, Oldmill, Ardglassie \& King Edward. }\end{array}$ & B \\
\hline 3 & $\sim 24 \mathrm{ka}$ & $\begin{array}{l}\text { Ice flow swings E or ENE across Buchan depositing Byth Till at Howe of } \\
\text { Byth, Hythie Till at Oldmill \& Kirkhill. }\end{array}$ & $\mathbf{R}$ \\
\hline 4 & $\sim 23 \mathrm{ka}$ & $\begin{array}{l}\text { Possible northward drawdown towards the Moray Firth when an ice } \\
\text { divide stretches from the Cairngorms towards Buchan. }\end{array}$ & $\mathbf{P}$ \\
\hline 5 & $\begin{array}{l}\text { 22-19 ka } \\
\text { LGM }\end{array}$ & $\begin{array}{l}\text { Thickening ice in Moray Firth and Strathmore coalesces in E Buchan } \\
\text { where a small enclave is occupied by } 80 \mathrm{~m} \text { Glacial Lake Ugie. } \\
\text { Deposition of Banchory, Essie (part), Hatton \& Mill of Forest tills. }\end{array}$ & B \\
\hline 6.1 & \multirow[t]{3}{*}{$\begin{array}{l}\text { 22-19 ka } \\
\text { LGM }\end{array}$} & $\begin{array}{l}\text { East Grampian ice retreats slowly in periglacial climate W across } \\
\text { Buchan leaving reticulate channel system. Enclave in E Buchan } \\
\text { enlarges, occupied by } 50 \mathrm{~m} \text { Lake Ugie. }\end{array}$ & C \\
\hline 6.2 & & $\begin{array}{l}\text { Strathmore ice re-advances onshore into Logie-Buchan and Glacial } \\
\text { Lake Ugie. End moraines formed at Cross-Stone }\end{array}$ & $\mathbf{R}$ \\
\hline 6.3 & & $\begin{array}{l}\text { Stagnation and decay of the Logie-Buchan ice lobe with deposition of } \\
\text { Kippet Hills S \& G. }\end{array}$ & $R / P$ \\
\hline 7.1 & \multirow[t]{2}{*}{$\sim 19 \mathrm{ka}$} & $\begin{array}{l}\text { Strathmore and East Grampian ice unzips down the eastern coast. } \\
\text { Widespread outwash. RSL at } 30 \text { OD. Tullos Clay. }\end{array}$ & $\mathbf{P}$ \\
\hline 7.2 & & $\begin{array}{l}\text { Minor readvance } \mathrm{N} \text { of Montrose? RSL at } 22 \mathrm{~m} \text { OD. Deposition of } \\
\text { glaciomarine Lunan Bay Clay. }\end{array}$ & $\mathbf{R}$ \\
\hline
\end{tabular}




\begin{tabular}{|c|c|l|l|}
\hline 8 & $18-17.5$ ka & $\begin{array}{l}\text { Fladen 1 Readvance SE into the Witch Ground, but contemporaneous } \\
\text { events in NE Scotland are unclear. }\end{array}$ & $\mathbf{B}$ \\
\hline 9 & $\begin{array}{c}17.5-16.2 \\
\mathrm{ka}\end{array}$ & $\begin{array}{l}\text { Fladen 2 Readvance SE towards Bosies Bank. Subsequent minor } \\
\text { readvance of Moray Firth ice around Fraserburgh? }\end{array}$ & $\mathbf{B}$ \\
\hline 10 & $\sim 16 \mathrm{ka}$ & $\begin{array}{l}\text { Moray Firth ice advances onshore at St Fergus. RSL at 12 m OD. } \\
\text { Deposition of glaciomarine St Fergus Silts. }\end{array}$ & $\mathbf{R}$ \\
\hline 11 & $\sim 16-15 \mathrm{ka}$ & $\begin{array}{l}\text { Moray Firth ice pinned along Banffshire coast damming ice-marginal } \\
\text { lakes. Retreat of East Grampian ice interrupted by limited re-advance } \\
\text { to N depositing the 'Northern Drift' and Blairdaff Moraine Fm. }\end{array}$ & $\mathbf{B / C}$ \\
\hline 12 & $\sim 14-15$ & Elgin Oscillation. Ponding in the lower reaches of Strathspey. & $\mathbf{R}$ \\
\hline
\end{tabular}

Table 11. The lithostratigraphy at Kirkhill and Leys quarries relating to the last glacial-interglacial cycle. Note: Due to the position of the sites in eastern Buchan, and the accommodation space available in channels/basins, this complex stratigraphy does not exceed $2.5-3.0 \mathrm{~m}$ in total thickness.

\begin{tabular}{|l|l|l|l|}
\hline Unit & Formal name (McMillan et al. 2011a) & Old name (Hall \& Jarvis 1993a) & MIS \\
\hline 16 & Manse Gelifluctate Bed & Kirkhill Gelifluctate 5 & 2 \\
\hline 15 & Kirkhill Church Sand Formation & Kirkhill Upper Sands & 2 \\
\hline 14 & East Leys Till Formation & East Leys Till & 2 \\
\hline 13 & Hythie Till Formation & Kirkhill Upper Till & $3 / 2$ \\
\hline 12 & Corse Diamicton Formation & Corse Diamicton & $3 / 2$ \\
\hline 11 & Corsend Gelifluctate Bed & Kirkhill Gelifluctate 4 & $4 ?$ \\
\hline 10 & Fernieslack Palaeosol Bed & Kirkhill Upper Buried Soil & 5 e \\
\hline
\end{tabular}

Table 12. Summary of events in Argyll. See Table 2 for abbreviations. Stages and ages modified after Finlayson et al. (2014) and Chiverrell et al. (2018).

\begin{tabular}{|l|l|l|l|}
\hline Stage & Age & Events, palaeo-environments and important units \\
\hline & MIS 5e & $\begin{array}{l}\text { Raised rock platforms and overlying beach gravels probably formed } \\
\text { in western Kintyre (now till covered). }\end{array}$ & I \\
\hline & MIS 5a-d & No evidence reported. & \\
\hline 1 & MIS 4 & $\begin{array}{l}\text { Early Devensian glaciation likely, but no indisputable evidence. } \\
\text { Raised glaciomarine deposits claimed to occur in W Islay. }\end{array}$ & B \\
\hline 2 & MIS 3 & Cold-water marine sediment laid down off Kintyre later to be rafted. & \\
\hline $32-25$ ka? & $\begin{array}{l}\text { Ice advance against reverse slopes along western Kintyre with } \\
\text { emplacement of glacial rafts of shelly marine sediment at Tangy } \\
\text { Glen. }\end{array}$ & $\begin{array}{l}\text { Ice sheets over western Highlands and Southern Uplands merge with } \\
\text { N-S divide across the Outer Firth of Clyde from which ice flows WNW } \\
\text { towards Malin Shelf. Scottish ice advances into Belfast Lough in } \\
\text { Northern Ireland before an ice divide forms across over the North } \\
\text { Channel linking Scottish and Irish ice sheets. }\end{array}$ & B \\
\hline 3 & $25-22$ ka? & $\begin{array}{l}\text { Enhanced drawdown towards shelf edge causes ice divide over the } \\
\text { Outer Firth of Clyde to migrate some 60 km to E. Cold-based ice } \\
\text { protects mountains of Arran. The ice divide sits across the Clyde } \\
\text { basin during the LGM. }\end{array}$ & P/B \\
\hline 4 & $\begin{array}{l}22-19 \text { ka? } \\
\text { LGM }\end{array}$ & $\begin{array}{l}\text { Main N-S ice divide migrates W towards Arran following substantial } \\
\text { thickening. E-W divide links Southern Uplands with Irish ice sheet } \\
\text { over Antrim. Cold-based ice protects mountains of Arran. }\end{array}$ & B \\
\hline
\end{tabular}




\begin{tabular}{|l|l|l|l|}
\hline SR & $\begin{array}{l}19.2-18.2 \\
\mathrm{ka}\end{array}$ & $\begin{array}{l}\text { Scottish Readvance, as established across the northern Irish Sea } \\
\text { basin and Solway. }\end{array}$ & $\mathbf{B}$ \\
\hline 5 & $\sim 16.5 \mathrm{ka}$ & $\begin{array}{l}\text { Eastern half of E-W divide breaches and ice flows SSW through } \\
\text { Outer Firth of Clyde. Eventual collapse of western half of the divide } \\
\text { allows Scottish ice to advance SW into Northern Ireland. }\end{array}$ & $\mathbf{P}$ \\
\hline 6 & $\begin{array}{l}\sim 16.5-16.2 \\
\mathrm{ka}\end{array}$ & $\begin{array}{l}\text { Ice becomes topographically constrained. Minor re-advances of } \\
\text { locally-sourced ice on Arran at c. 16.2 ka BP followed its separation } \\
\text { from outlet glaciers occupying the Kilbrannan Sound and Firth of } \\
\text { Clyde. }\end{array}$ & $\mathbf{P}$ \\
\hline 7 & $\sim 16.2 \mathrm{ka}$ & Deglaciation of the Outer Firth of Clyde. & $\mathbf{P}$ \\
\hline
\end{tabular}

Table 13. Summary of events in western central Scotland and Ayrshire. See Table 2 for abbreviations. Stages and estimated ages modified after Finlayson et al. (2010) and Finlayson (2012).

\begin{tabular}{|c|c|c|c|}
\hline Stage & Age & Events, palaeo-environments, important sites \& units & \\
\hline & MIS 5e & Raised rock platforms form around the Firth of Clyde (till covered). & $\mathbf{I}$ \\
\hline & MIS5a-d & No reported evidence. & \\
\hline & MIS 4 & $\begin{array}{l}\text { Possible ice flow from NW depositing Ballieston and Littlestone tills } \\
\text { during an Early Devensian glaciation. }\end{array}$ & B \\
\hline & MIS 3 & $\begin{array}{l}\text { Deposition of the Afton Lodge Clay in the Firth of Clyde basin. } \\
\text { Biogenic sediments deposited at Sourlie and Balglass. Bones } \\
\text { deposited in the Cadder Sand around Bishopbriggs. }\end{array}$ & C/IS \\
\hline A & $\sim 35-32$ & $\begin{array}{l}\text { Ice advances from NW against reverse slopes forming ribbed moraine. } \\
\text { Laminated Broomhill Clay laid down in proglacial lakes prior to being } \\
\text { over-ridden. Rafting of Afton Lodge Clay and deposition of Eglinton } \\
\text { Shelly Till in Ayrshire. Growth of Southern Uplands ice centre. }\end{array}$ & B \\
\hline B & $\begin{array}{l}32-25 \text { ka } \\
\text { LLGM }\end{array}$ & $\begin{array}{l}\text { N-S ice divide develops over the Firth of Clyde from which wide } \\
\text { corridor of fast-flowing flows E towards the Firth of Forth depositing } \\
\text { the Wilderness Till across central Scotland. }\end{array}$ & B \\
\hline C & $\begin{array}{l}25-22 \text { ka } \\
\text { LGM }\end{array}$ & $\begin{array}{l}\text { Enhanced drawdown to W causes eastward migration and lowering of } \\
\text { the N-S divide linking W Highlands and Southern Uplands ice centres. } \\
\text { The ice divide sits across the Clyde basin during the LGM. }\end{array}$ & P/B \\
\hline $\mathrm{D}$ & $22-19 \mathrm{ka}$ & $\begin{array}{l}\text { The N-S ice divide migrates back towards W and thickens over W } \\
\text { Highlands and the Firth of Clyde. }\end{array}$ & B \\
\hline & $\begin{array}{l}19-16.5 \\
\mathrm{ka}\end{array}$ & $\begin{array}{l}\text { Deglaciation commences with widespread cutting of ice-marginal } \\
\text { glacial drainage channels and ponding to } \mathrm{W} \text { of the regional E-W } \\
\text { watershed. }\end{array}$ & $\mathbf{P}$ \\
\hline $\mathrm{E}$ & $\begin{array}{l}16.5- \\
16.2 \mathrm{ka}\end{array}$ & $\begin{array}{l}\text { Ice streams E and SE into the Clyde basin during deglaciation. Ice-front } \\
\text { oscillations at Blantyreferme causes extensive ponding in the Clyde } \\
\text { valley upstream. }\end{array}$ & $\mathbf{P} / \mathbf{R}$ \\
\hline
\end{tabular}


Table 14. Summary of events in the Solway Lowlands. See Table 2 for abbreviations. Stages and estimated ages after Livingstone et al. (2012) and Chiverrell et al. (2018).

\begin{tabular}{|c|c|c|c|}
\hline Stage & Age & Events, palaeo-environments, important sites \& units & \\
\hline & MIS 5e & $\begin{array}{l}\text { Raised rock platforms formed around Port Logan at c. } 10 \mathrm{~m} \text { OD (now } \\
\text { till covered) (Sutherland 1993h). }\end{array}$ & I \\
\hline & MIS 5a-d & No reported evidence. & \\
\hline & MIS 4 & $\begin{array}{l}\text { Possible 'Early Advance' of Scottish ice up the Vale of Eden during an } \\
\text { Early Devensian glaciation. }\end{array}$ & B \\
\hline & MIS 3 & No reported evidence. & \\
\hline 1 & $\begin{array}{l}28-25 \text { ka } \\
\text { LLGM }\end{array}$ & $\begin{array}{l}\text { Likely time of 'Early Advance' of Scottish ice up the Vale of Eden laying } \\
\text { down the Chapelknowe Till near Gretna. }\end{array}$ & B \\
\hline 2 & $\begin{array}{l}25-22 \text { ka } \\
\text { LLGM }\end{array}$ & $\begin{array}{l}\text { An ice divide links the Cumbrian Mountains and Galloway Hills across } \\
\text { the Solway Firth, forcing ice E through the Tyne Gap and over } \\
\text { Stainmore, and probably NE into the Tweed catchment, laying down } \\
\text { the Gretna Till. Cold-based ice over the Langholm and Cheviot Hills. }\end{array}$ & B \\
\hline 3 & $\begin{array}{l}\sim 22-20 \mathrm{ka} \\
\mathrm{LGM}\end{array}$ & $\begin{array}{l}\text { Flow over Stainmore stops, but ice continues to flow } E \text { through the } \\
\text { Tyne Gap. }\end{array}$ & $\mathbf{P}$ \\
\hline 4 & $\sim 20 \mathrm{ka}$ & $\begin{array}{l}\text { The ice divide over the Solway Firth breaches followed by partial } \\
\text { deglaciation of the Solway Lowlands where varved clays are deposited } \\
\text { near Carlisle (Blackhall Wood Glaciolacustrine Fm). Cessation of flow } \\
\text { through the Tyne Gap. }\end{array}$ & $\mathbf{P}$ \\
\hline 5 & $\begin{array}{l}\sim 20-19.2 \\
\mathrm{ka}\end{array}$ & $\begin{array}{l}\text { Ice re-advances into the Solway Lowlands and streams towards the } \\
\text { Irish Sea basin partially remoulding the Gretna Till (Blackhall Wood } \\
\text { Readvance). }\end{array}$ & B \\
\hline 6 & $\begin{array}{l}\text { 19.2-18.2 } \\
\mathrm{ka}\end{array}$ & $\begin{array}{l}\text { Another partial deglaciation and glacial reorganisation in the Solway } \\
\text { Lowlands. Deposition of the Plumpe Sand and Gravel near Gretna. }\end{array}$ & $\mathbf{P}$ \\
\hline 7 & $\begin{array}{l}\text { 18.2- } 17 \\
\mathrm{ka}\end{array}$ & $\begin{array}{l}\text { Ice readvances SE across the inner Solway laying down the Plumpe } \\
\text { Bridge Till } M b \text { of the Gretna Till (Scottish Readvance). Ponding of ice } \\
\text { marginal lakes including 'Glacial Lake Carlisle'. }\end{array}$ & B \\
\hline 8 & 17-16 ka & $\begin{array}{l}\text { Deglaciation punctuated by minor readvances of Southern Upland ice } \\
\text { near Langholm and Powfoot (Fig. 31F). Widespread ponding and } \\
\text { glaciofluvial deposition. Galloway Hills deglaciated by } 15.2 \mathrm{ka} \text {. }\end{array}$ & $\mathbf{P}$ \\
\hline
\end{tabular}




\section{Late Pleistocene Figure captions}

\section{Figures}

1. Summary of Late Quaternary chronostratigraphic stages (Great Britain) and their correlation with Marine Isotope Stages (MIS) (after Lisiecki \& Raymo 2005; Bradwell et al. 2008a; Otvos 2015). The approximate timings of the local Last Glacial Maximum (LLGM) (c. 30-27 ka) (Ballantyne \& Small 2018) and global LGM (23-21 ka) (Hughes et al. 2016) are shown. Note that some terrestrial stage boundaries are not coincident with MIS boundaries. DS: Dimlington Stadial. WI: Windermere Interstadial. LLS: Loch Lomond Stadial.

2. Greenland oxygen isotope record from the North Greenland Ice Core Project (NGRIP) ice core (NGRIP Members 2004) and the main event stratigraphy (Rasmussen et al. 2014). The age scale is based on the GIC05 age model as plotted by Abbott et al. (2012) (Reprinted from Quaternary Science Reviews, 36, 59-77, P. M. Abbott et al. 'A detailed framework of marine Isotope Stages 4 and 5 volcanic events recorded in two Greenland ice-cores', Copyright (2012), with permission from Elsevier). GI: Greenland Interstadials; GS: Greenland Stadials. MIS boundaries are based on Lisiecki \& Raymo (2005), Railsback et al. (2015) and Otvos (2015). The indicative presence of glaciers in Scotland is adapted from Clapperton (1997): MIF: mountain icefields; IS: Ice sheets; MIC: mountain ice caps; MG: small mountain glaciers.

3. Distribution of glacigenic subgroups (A) and superficial till units (B) (modified from McMillan et al. 2011a). C: Cairngorms. G: Gaick. R: Rannoch Moor.

4. Evidence for the pattern of ice flow on Shetland (modified from Hall 2013). A. Directions of glacial erratic carry. B. Measurements of striae, excluding disputed early records (from Peach \& Horne 1879). C. Palynomorph records for till matrix at key sites (J.B. Riding, pers. comm. 2016) [Sample sites: 1. Vidlin Voe; 2. Sand Voe; 3. Colla Firth; 4. South Nesting; 5. Salt Wick; 6. Wick of Collaster; 7. Norwick; 8. Westing; 9. The Bugg; 10. Sand Wick; 11-13. Breiwick; 14. Little Bixter; 15. Sand of Hayes; 16. Da Ristie Nessies]. D. Ice flow directions from roches moutonnées.

1. The stratigraphy at Fugla Ness, Shetland (modified from Hall et al. 2002).

6. The stratigraphy at Sel Ayre, Shetland (modified from Hall et al. 1993a).

7. Till stratigraphy (A) and striae (B) in Caithness and Orkney (modified from Hall \& Riding 2016 and Hall et al. 2016a). 1. Unconformity or disconformity within a till unit. 2. Sand or gravel layer. 3. Western limit of the Forse Till derived from the inner Moray Firth in Caithness and Sutherland.

8. Sections of stacked tills on Orkney (modified from Hall et al. 2016a).

9. Records of glacial erratics in Caithness and Orkney (modified from Hall \& Riding 2016 and Hall et al. 2016a).

10. Domains and transport directions for glacial erratics recorded on Caithness, Orkney and Shetland. WG Witch Ground. Shetland rocks (blue arrows) are confined to Shetland, including Fair Isle, and the surrounding shelf. Scandinavian erratics (dark green arrows) occur on N Orkney, Fair Isle and at one location in southernmost Shetland. Carboniferous limestone, sandstone and volcanic clasts from the Firth of Forth and eastern Scotland (pale 
green arrows) are recorded only from Fair Isle and N Orkney. Igneous and metamorphic erratics from NE Scotland (orange arrows) occur along the shores of the Pentland Firth, in N Orkney and on Fair Isle. Erratics from the Northern Highlands (red arrows) are recorded as far north as N Ronaldsay. Jurassic and Lower Cretaceous rocks and fossils from the inner Moray Firth (purple arrows) occur in Caithness (Gordon 1993d) and N Orkney. Erratics of Late Cretaceous chalk and flint (yellow arrows and outcrop) are found $\mathrm{N}$ of Wick and along the Pentland Firth, locally in high concentrations, and in N Orkney. Flint is found in tills on Fair Isle, but may be derived originally from sources in the Danish sector of the North Sea.

11. The stratigraphy at Wester Clett, Caithness (from Hall et al. 2011). See Table 4 for abbreviations.

12. Time frame and glaciation curve for the main events of the last ice sheet on the AtlanticNorth Sea Divide. GISP2 ice core data from Stuiver \& Grootes (2000); binge-purge cycles and ice extent from Hubbard et al. (2009); till stratigraphy from Hall \& Riding (2016) and Hall et al. (2016a). DT: Dunbeath Till; DHT: Drumhollistan Till; FT: Forse Till; PST: Portskerra Till; QT: Quendale Till; STT: Scara Taing Till; WT: Wick Till.

13 Physiography of the NW Highlands and Outer Hebrides showing the position of the former Minch Ice Stream (modified after Bradwell \& Stoker 2015). Hill-shaded surface model built from Intermap Technologies NEXTMap Britain elevation data.

14. The Galson Raised Beach on NW Lewis. A. South Galson. Undisturbed storm beach gravel of likely MIS 5 e age at $\sim 5 \mathrm{~m}$ OD overlain by cryoturbated gravel with erect clasts and layers of gravel-rich diamicton (Lewis Till) deposited by local ice. B. Eoropie. A small raft of Galson Raised Beach gravel within brown mud-rich diamicton (Port Beag Till) deposited by the Minch Palaeo Ice Stream.

15. Generalized stratigraphy at Tolsta Head on NW Lewis (modified from Gordon \& Sutherland 1993b).

16. Hirta, St Kilda, looking SW to Dùn, showing tor landforms mantled by thick periglacial slope deposits.

17. Transport paths of some indicator erratics across the inner Moray Firth (after Mackie 1905; Sissons 1967a; Fletcher et al. 1996; Merritt et al. 2017a). Hill-shaded surface model built from Intermap Technologies NEXTMap Britain elevation data.

18. Megagrooves on the western flank of Suidhe Ghuirmain in the Endrick valley, $\mathrm{N}$ of the Great Glen, looking SE. Inset: rock drumlin associated with the megagrooves. Ice flowed towards the Moray Firth, to the NE (left). See preceding figure for location.

19. Summary logs of sections recorded at Dalcharn (modified after Walker et al. 1992).

20. The Allt Odhar section showing details of the Odhar Peat Formation and the position of the sampling points for pollen, insect and plant macrofossil remains (modified from Walker et al. 1992). The terminology follows McMillan et al. (2011a).

21. Transport paths of some indicator erratics in NE Scotland (after Read 1923; Bremner 1928; Synge 1956; Sissons 1967a; Merritt et al. 2003). Hill-shaded surface model built from Intermap Technologies NEXTMap Britain elevation data. 
22. Summary logs of sections recorded at the Howe of Byth Quarry, SW of Fraserburgh (modified after Hall \& Connell 2000).

23. Conceptual glacial reconstructions depicting stages in the evolution of the NE quadrant of the last BIIS (from Merritt et al. 2017a with minor modification). (Reprinted from Journal of Quaternary Science, 32, 276-94, Merritt, J. W., Connell, E. R. \& Hall, A. M., 'Middle to Late Devensian glaciation of north-east Scotland: implications for the north-eastern quadrant of the last British-Irish ice sheet'. Copyright (2017), with permission from Wiley). (A) Reconstruction similar to that of Boulton et al. (1985, fig. 10) (stage 1); (B) LLGM (stage 2); (C) Considerable thinning and glacial reorganisation during stages 3 and 4; (D) Re-expansion following possible marine ingression into the Witch Ground basin during stage 5, followed by probable coalescence of BIIS and the Norwegian Channel Ice Stream at the Tampen Ridge (see cartoon 6 for limits); (E) Marine ingression to Lunan Bay during Stage 7; (F) Stages 8-12 and other limits after Clark et al. (2012, fig. 12 and 13). Red hexagons show the centre of the Witch Ground basin. Ice divides shown by thick black lines with open diamonds; single filled ticks denote ice divide receding by ice stream headward scavenging.

24. Generalised stratigraphy recorded at Boyne Quarry in 2014, E of Portsoy: encircled letters refer to units described by Peacock \& Merritt (2000a).

25. Subglacially streamlined features and ice marginal glacial drainage channels around Boyne Quarry and the Howe of Byth sites (modified after Merritt et al. 2017a). Flowsets (fs) after Hughes et al. 2014. Hill-shaded surface model built from Intermap Technologies NEXTMap Britain elevation data.

26. Reconstruction of ice-free enclaves and proglacial lakes in Buchan (modified after Merritt et al. 2017a): (a) confluence between ice lobes during stage 5, creation of $80 \mathrm{~m}$ Glacial Lake Ugie (GLU) followed by the 'Logie-Buchan Readvance' and creation of $50 \mathrm{~m} \mathrm{GLU}$ during stage 6; (b) decay of the Logie-Buchan ice lobe, further retreat of East Grampian ice followed by re-advance of Moray Firth ice during stages 7-9; (c) St. Fergus Readvance and subsequent ponding during glacial retreat along the Banffshire coast during stages 10-11.

27. Eight stages $(\mathrm{A}-\mathrm{H})$ of the growth and decay of the last BIIS over western Scotland, the North Channel and NE Ireland (modified after Finlayson et al. 2014). Diagonal shading denotes probable cold-based ice. Dashed lines denote ice divides. Age estimates modified in respect of the recently published age of the Scottish Readvance determined by Chiverrell et al. (2018). Hill-shaded surface model built from Intermap Technologies NEXTMap Britain elevation data.

28. Simplified glacial lithostratigraphy for the Clyde and Ayrshire basins (after McMillan et al. 2011a). Fm: formation; Mbr: member; LLS: Loch Lomond Stadial; LI: Lateglacial Interstadial. Greenland Ice Core GICC05 Chronology events after Lowe et al. (2008b); GS: Greenland Stadial; GI: Greenland Interstadial.

29. Reconstructed stages (A-F) of glaciation in the West Central Lowlands (modified from Finlayson 2012). Clyde basin outlined in red. AF: Afton Lodge; CE: Carstairs Eskers; G: 
Grangemouth; GG: Glengavel; FF: Firth of Forth. Hill-shaded surface model built from Intermap Technologies NEXTMap Britain elevation data.

30. Glacial geomorphology and geology of the Clyde and Ayrshire basins (from Finlayson et al. 2010 with minor modification). (Reprinted from Quaternary Science Reviews, 29, 969-88, Finlayson, A., Merritt, J.W. Browne, M., Merritt, J.E., McMillan, A. \& Whitbread, K. Ice sheet 'advance, dynamics and decay configurations: evidence from west central Scotland'. Copyright (2010), with permission from Elsevier). Erratic limits are from Eyles et al. (1949) and glacial striations from Paterson et al. (1998).

31. Reconstructed stages (A-F) of glaciation around the Solway Firth (from Livingstone et al. 2012, trimmed and with minor modification). (Reprinted from Earth-Science Reviews, 111, 25-55, Livingstone, S. J., Evans, D. J. A., O’Cofaigh, C., Davies, B. J., Merritt, J. W., Huddart, D., Mitchell, W. A., Roberts, D. H. \& Yorke, L., 'Glaciodynamics of the central sector of the last British-Irish Ice Sheet in Northern England'. Copyright (2012), with permission of Elsevier). Dashed-dotted lines refer to ice divides (with the thick dotted lines indicating possible ice-saddles) and the arrows indicate ice flow vectors (dotted arrows indicate alternative ice flow scenarios). Hill-shaded surface model built from Intermap Technologies NEXTMap Britain elevation data. 


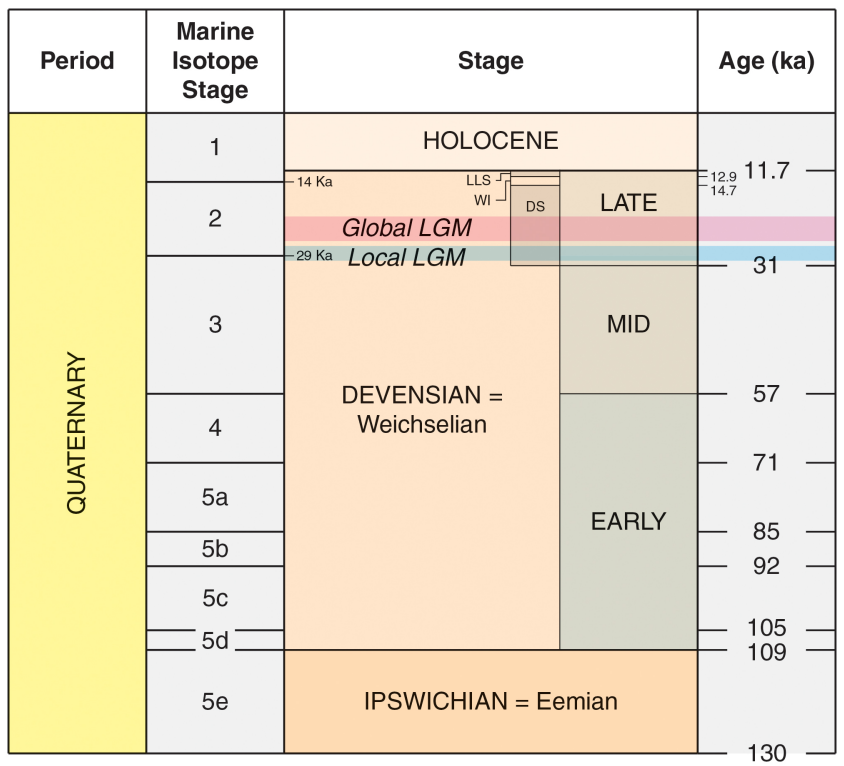




\section{A}

\section{Caledonia Glacigenic Group}

\begin{tabular}{|c|c|c|c|}
\hline Shetland & Mearns & C & Cairngorms \\
\hline Western Isles & Midland Valley & $\mathbf{G}$ & Gaick \\
\hline $\begin{array}{l}\text { North West } \\
\text { Highlands }\end{array}$ & Borders & $\mathbf{R}$ & Rannoch Moor \\
\hline $\begin{array}{l}\text { Banffshire Coast, } \\
\text { Caithness and Orkney }\end{array}$ & Southern Uplands & & \\
\hline Inverness & Irish Sea Coast & & \\
\hline East Grampian & Cheviot & & \\
\hline Logie-Buchan & North Pennine & & \\
\hline Central Grampian & North Sea Coast & & \\
\hline
\end{tabular}

Cross-hatching shown where deposits of more than one subgroup are known to interdigitate.

Major overlaps are identified by stripes, where the thin bands represent the concealed units.

Some simplification necessary at this scale.

\section{B}

\section{Surficial till units within subgroups}

SHETLAND

1 Burrier Wick Till

WESTERN ISLES

\begin{tabular}{|c|l}
\hline $\mathbf{2}$ & Lewis Till Fm \\
\hline $\mathbf{3}$ & Port Beag Till Fm \\
\hline
\end{tabular}

NORTH WEST HIGHLANDS

\begin{tabular}{|c|l}
\hline 4 & Assynt Glacigenic Fm \\
\cline { 1 - 1 } 5 & $\begin{array}{l}\text { Thormaid Till Mb } \\
\text { (Reay Burn Till Fm) }\end{array}$ \\
\hline
\end{tabular}

BANFFSHIRE COAST

and CAITHNESS

\begin{tabular}{|c|l}
\hline 6 & $\begin{array}{l}\text { Reisgill Burn } \\
\text { Till Fm }\end{array}$ \\
\cline { 1 - 1 } 7 & \multirow{2}{*}{ Essie Till Fm } \\
\hline
\end{tabular}

\section{INVERNESS}

8 Finglack Till Fm
EAST GRAMPIAN

9 Banchory Till Fm

LOGIE-BUCHAN

10 Hatton Till Fm

CENTRAL GRAMPIAN

11 Ardverikie Till Fm

12 Till Fm Uain

13 Gartocharn Till Fm

MEARNS

$14 \begin{aligned} & \text { Mill of Forest } \\ & \text { Till Fm }\end{aligned}$

MIDLAND VALLEY

15 Wilderness Till Fm BORDERS

16 Norham Till Fm
SOUTHERN UPLANDS

\begin{tabular}{|c|l}
17 & Langholm Till Fm \\
\cline { 1 - 1 } 18 & $\begin{array}{l}\text { New Abbey Till Mb } \\
\text { (Langolm Till Fm) }\end{array}$ \\
\hline
\end{tabular}

IRISH SEA COAST

\begin{tabular}{|r|l}
\hline 19 & Jurby Fm \\
\cline { 1 - 1 } 20 & \multirow{2}{*}{ Gretna Till Fm } \\
\hline
\end{tabular}

CHEVIOT

21 Kale Water Till Fm

NORTH PENNINE

\begin{tabular}{|r|l}
\hline 22 & Acklinton Till \\
\cline { 1 - 1 } 23 & Wear Till Fm \\
\hline
\end{tabular}

NORTH SEA COAST

24 Horden Till Fm

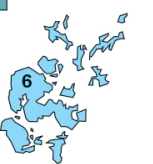

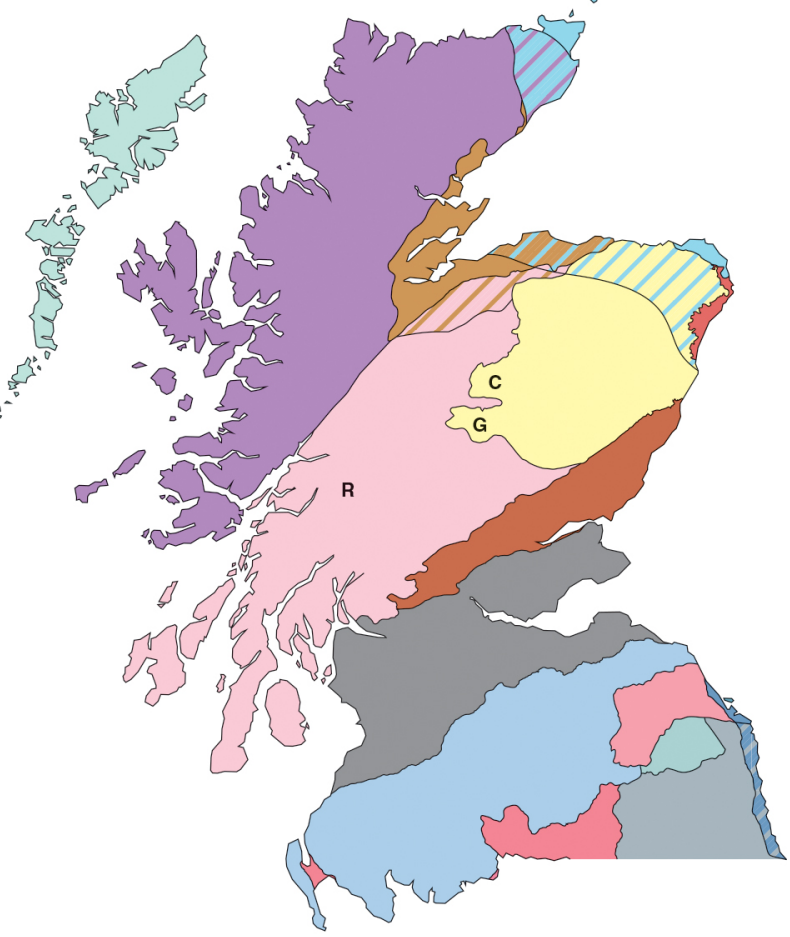

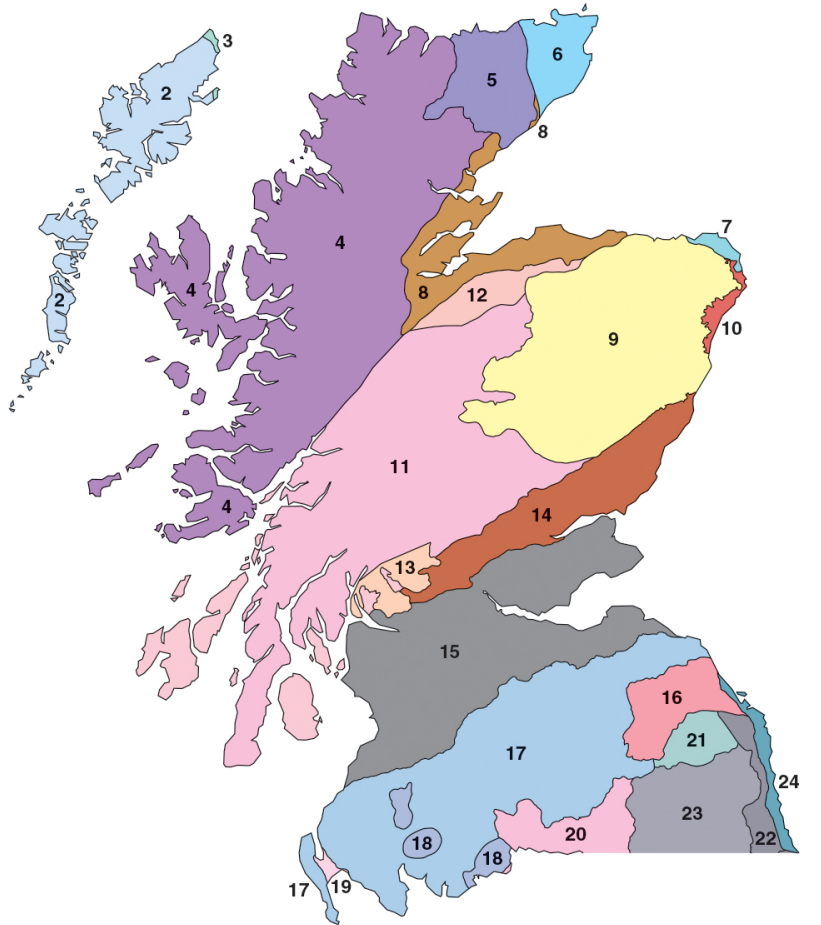




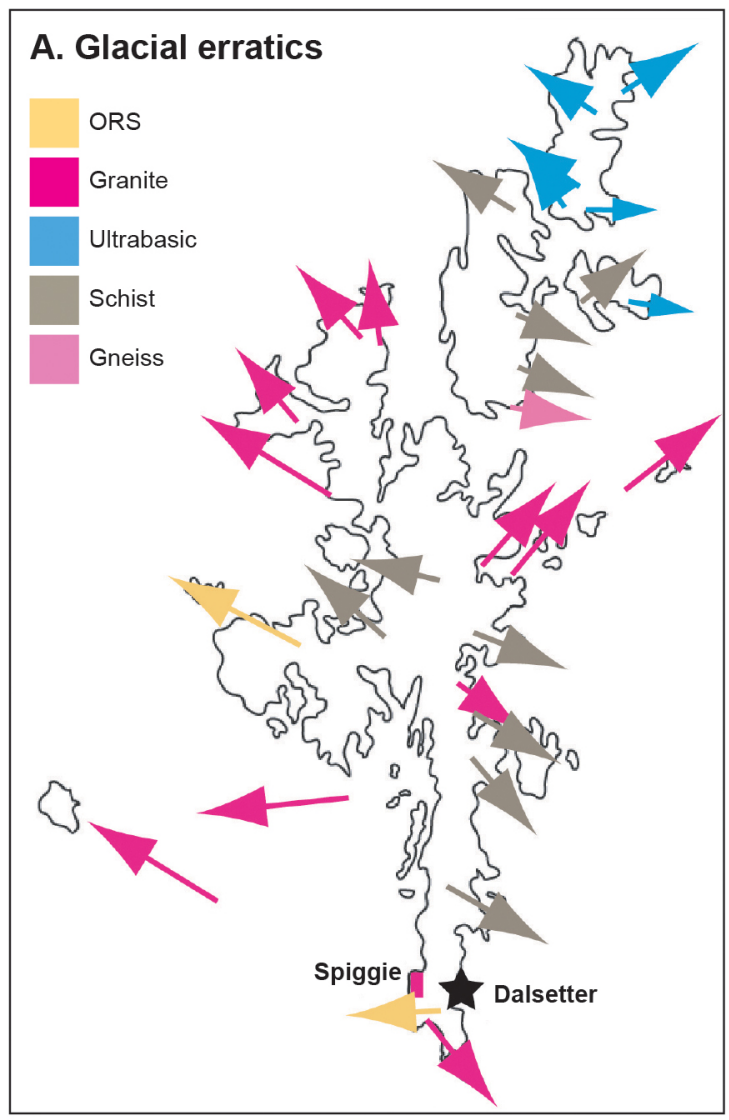

B. Striae

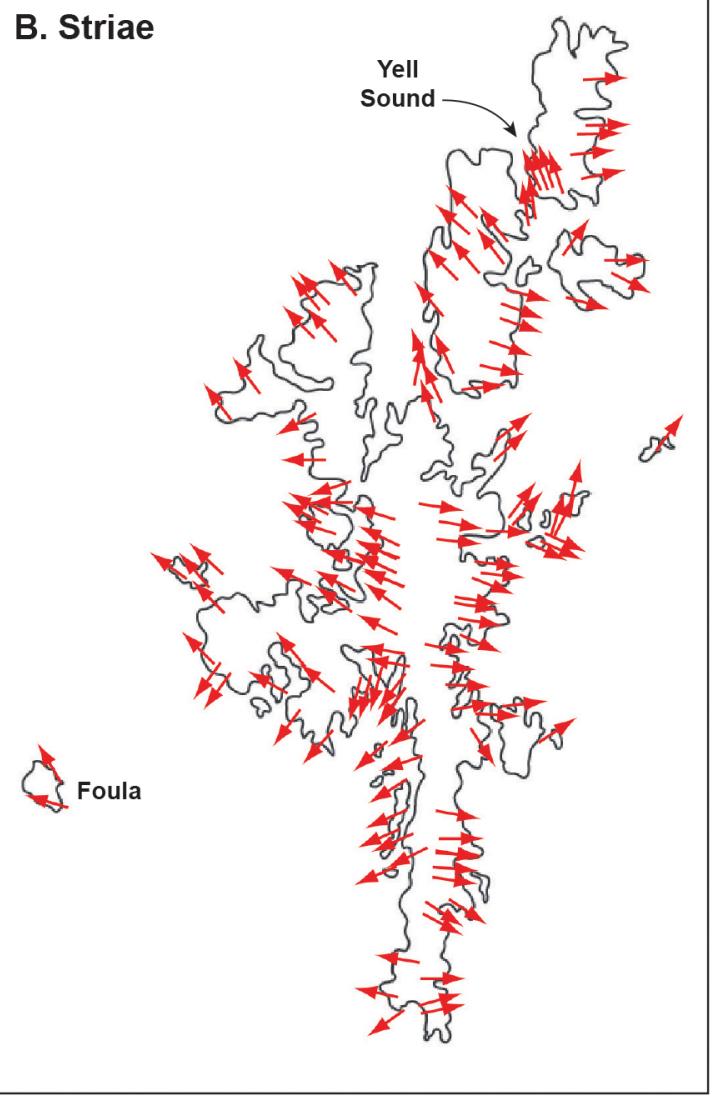

\section{Palynomorphs}

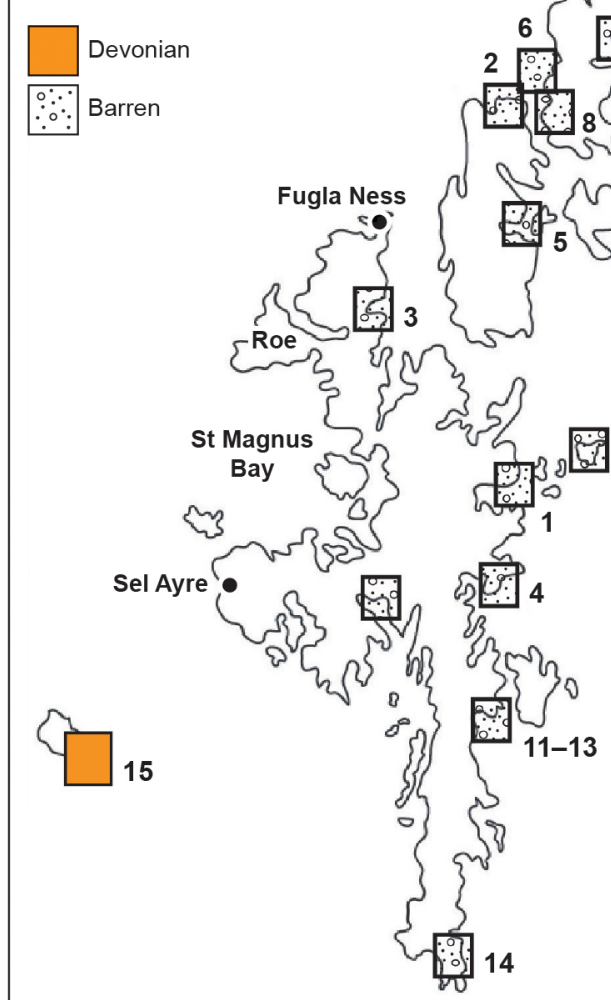

D. Roches Moutonnées

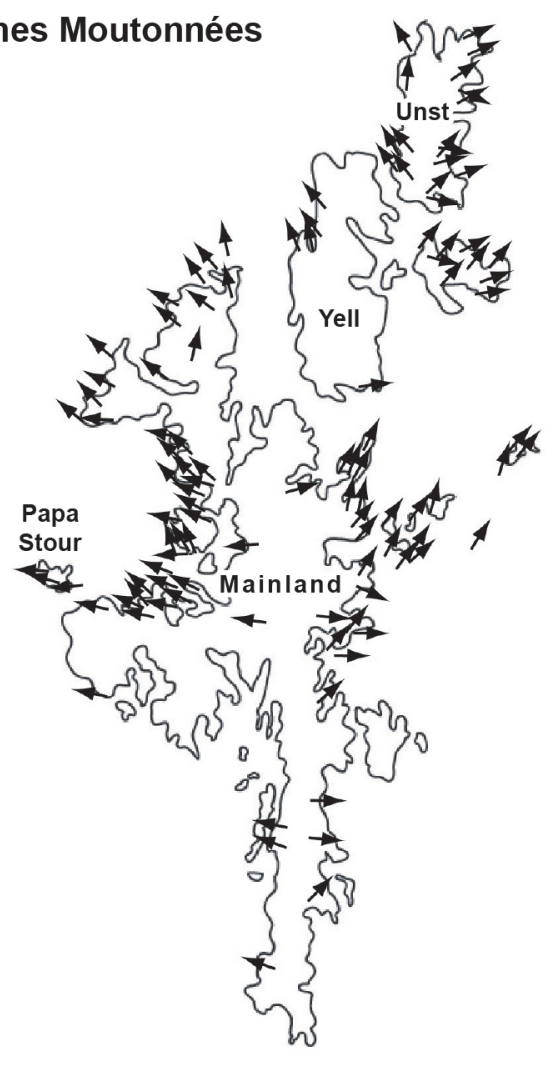




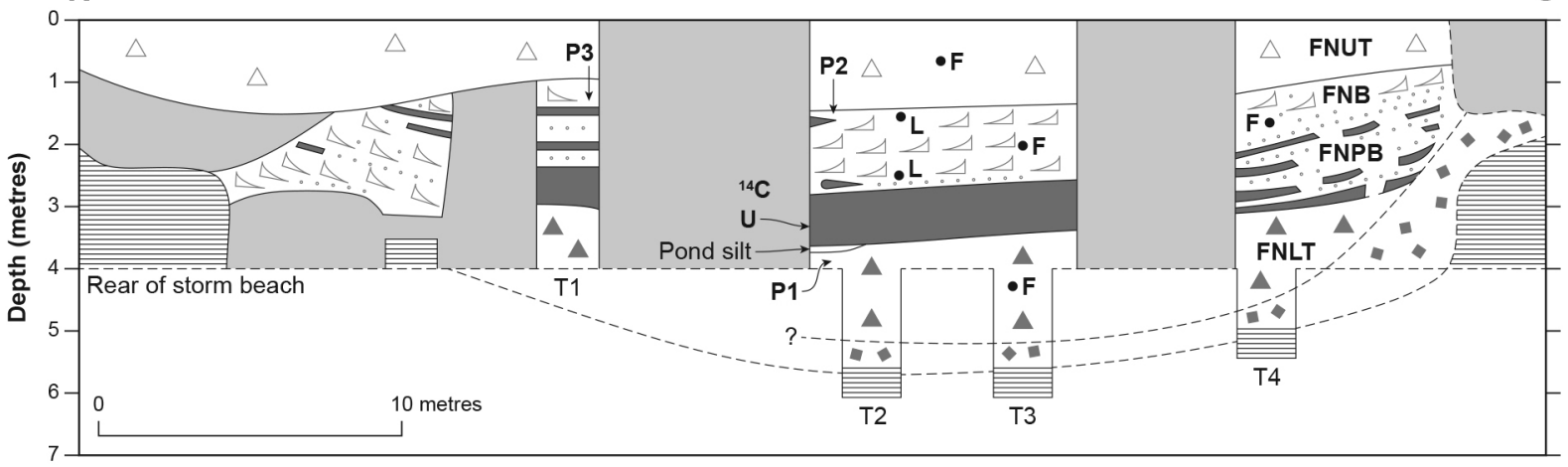
$\square$ Talus
Fugla Ness Peat Bed (FNPB)
${ }^{14} \mathrm{C} ・$ Radiocarbon sample
Fugla Ness Lower Till (FNLT)
L- Luminescence sample
Fugla Ness Upper Till (FNUT)
Rock face breccia
F - Fabric sample
Fugla Ness Breccia (FNB)
Bedrock
U Uranium series sample
P Pollen sample 


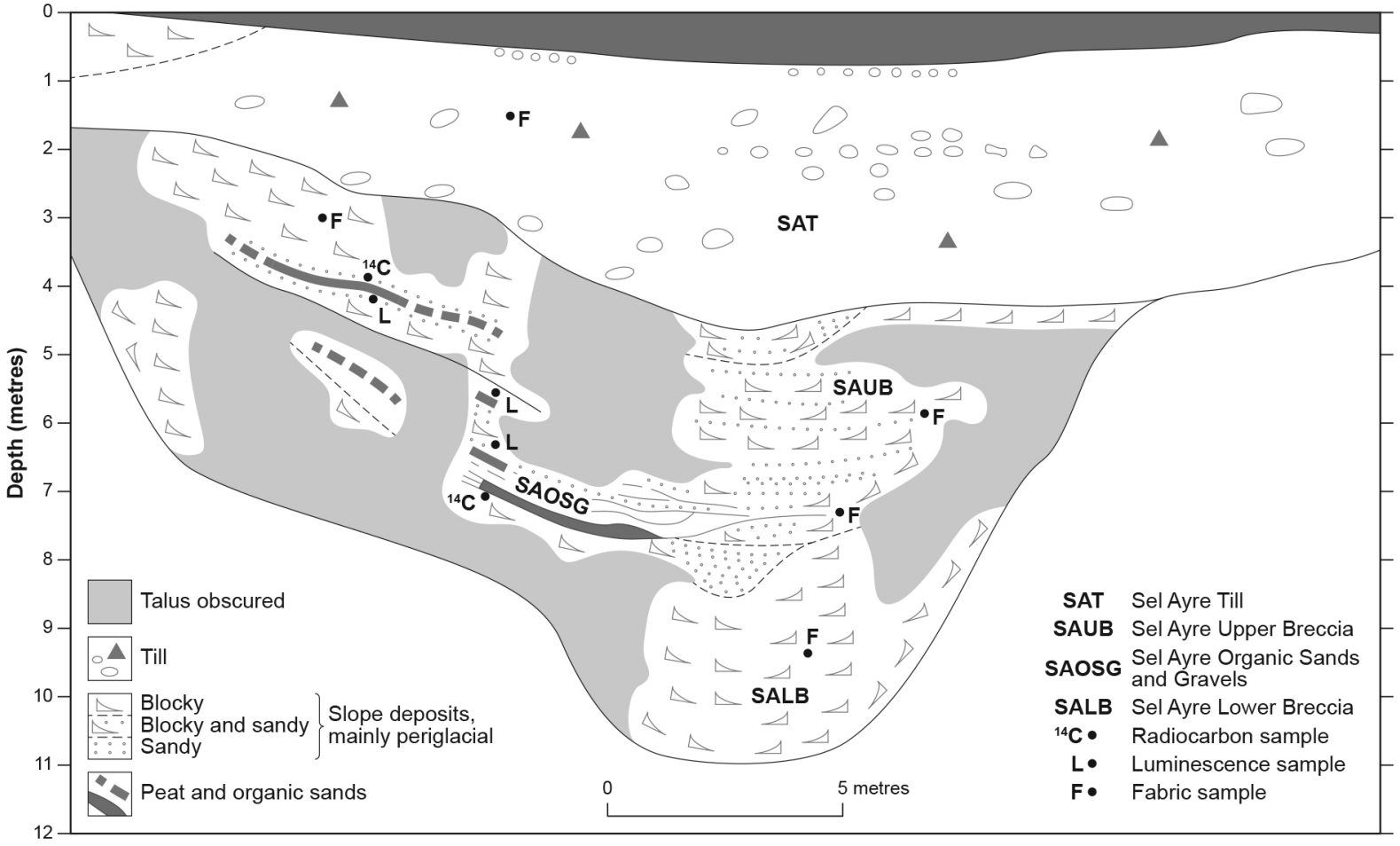




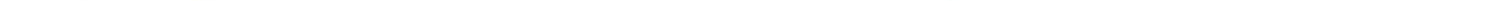


Den Wick

Eastern Mainland

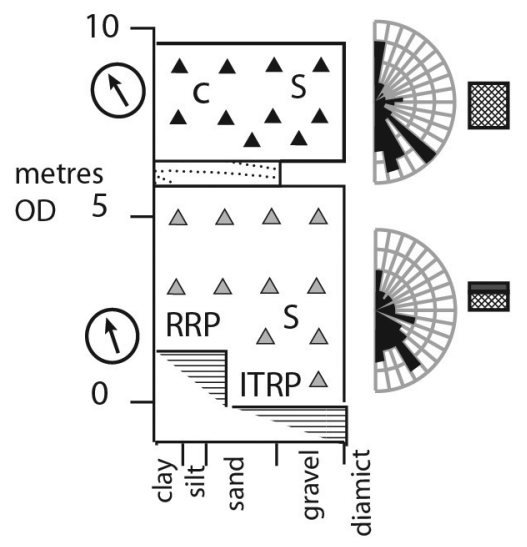

Sands of Mussetter

Eday

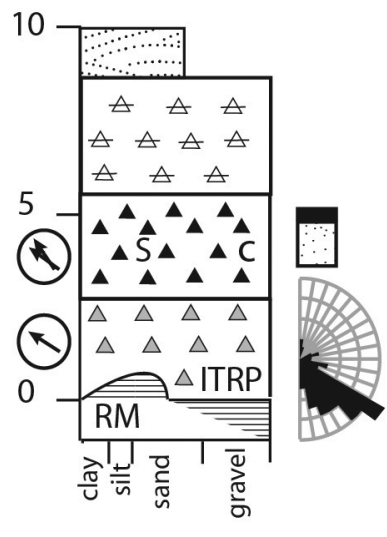

Bay of Newark

Eday

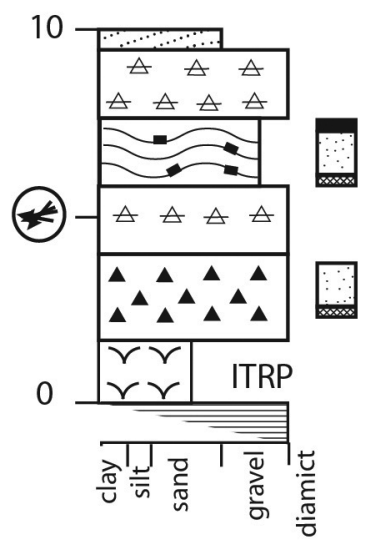

Scara Taing Rousay

Moraine ridges

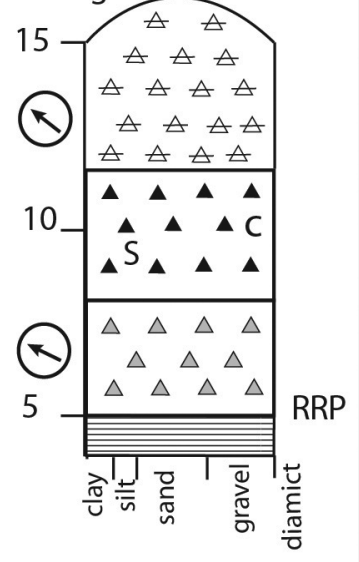

$\Delta \Delta$ Quendal Till $\Delta \Delta$ Scara Taing Till $\Delta \Delta$ Digger Till $\because$ ITRP Inter-tidal rock platform RRP Raised Rock Platform RM Roche moutonnée c Chalk clasts S Shell fragments
ITRinated mud-rich diamicton 


\section{Inner Moray Firth}

F Upper Cretaceous flint and chalk

$\square$ Lower Cretaceous

Jurassic fossils

Carboniferous limestone and sandstone

\section{Northern Highlands}

- Cambrian Pipe Rock

- Helmsdale Granite

- Inchbae augen gneiss

- Dark grey biotite gneiss

\section{Grampian Highlands}

A Gabbro

$\triangle$ Serpentinite

$\triangle$ Marble

$\triangle$ Pelitic schist and gneiss

\section{Orkney}

$\because$ ORS Eday Group

\section{Fennoscandia}

* Rhomb porphyry and other indicators

is Light grey gneisses, likely derived from southern Norway and Sweden
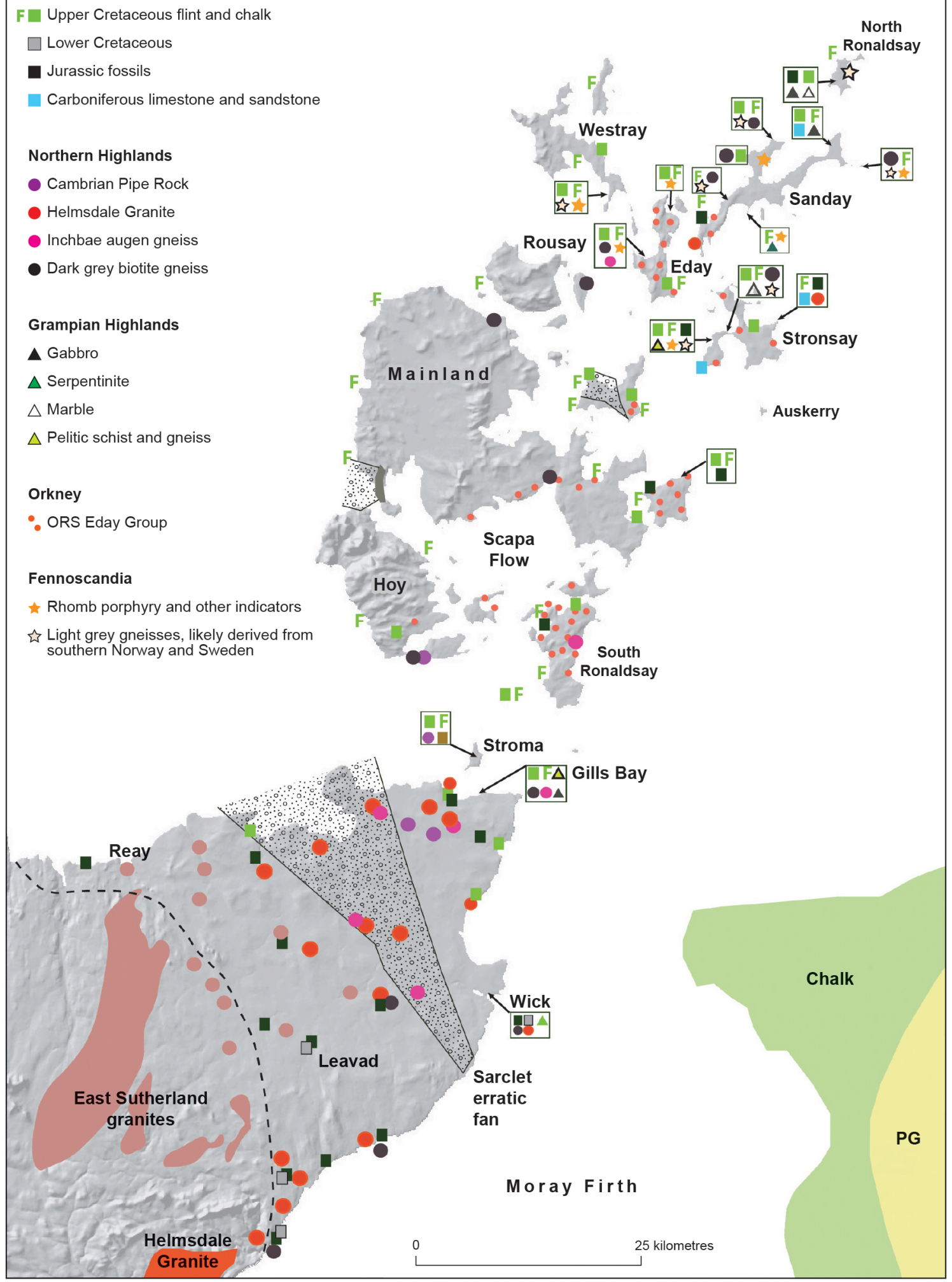

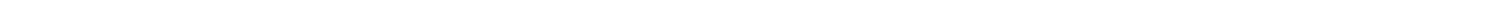


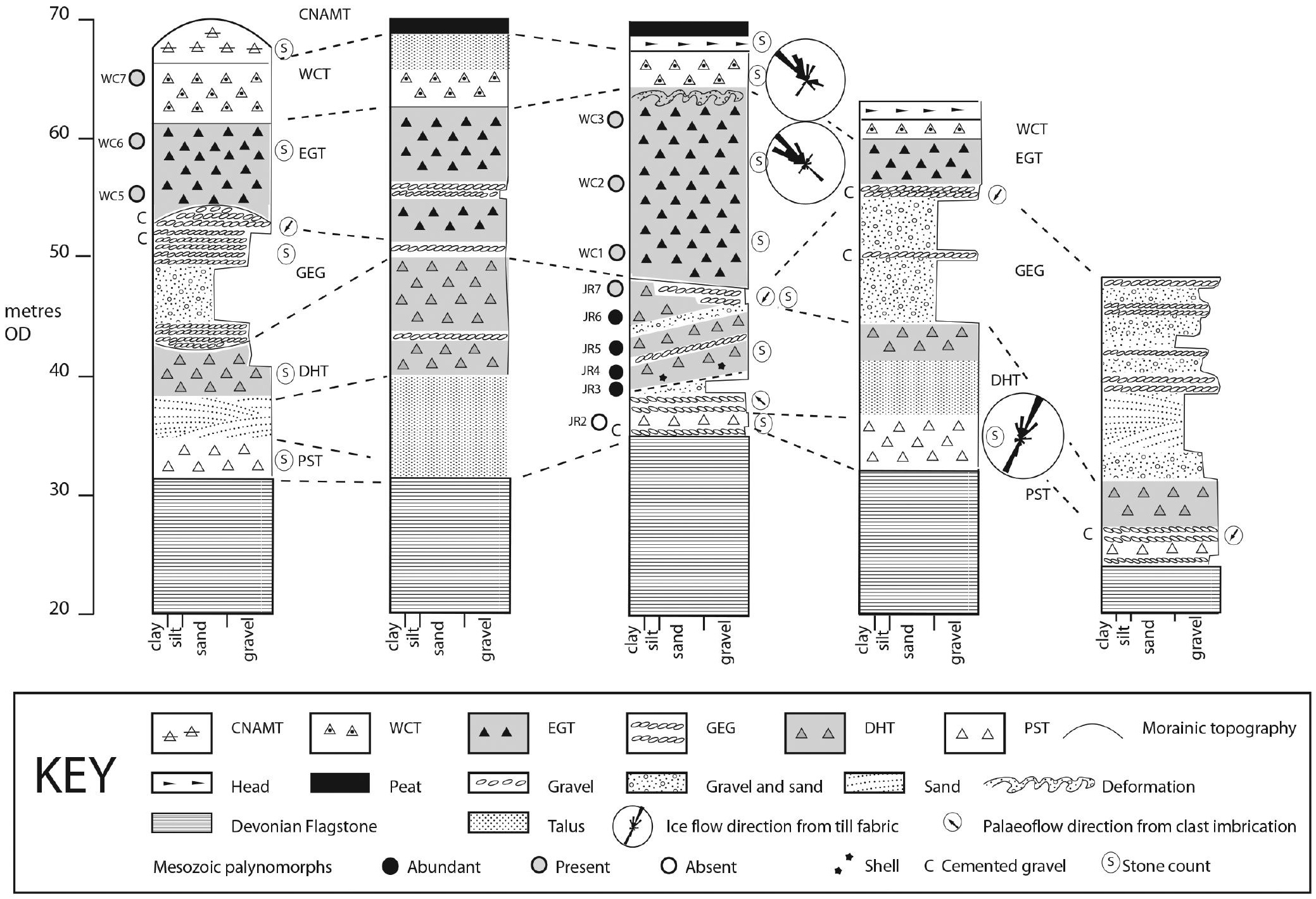



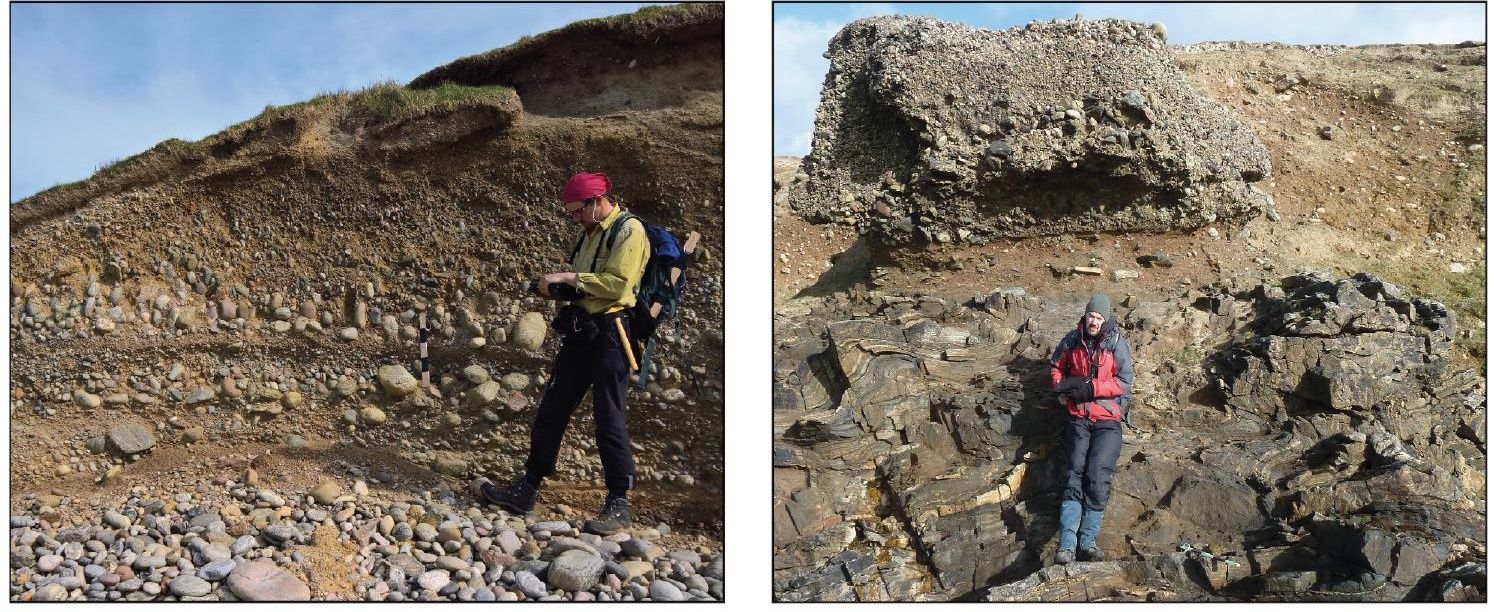


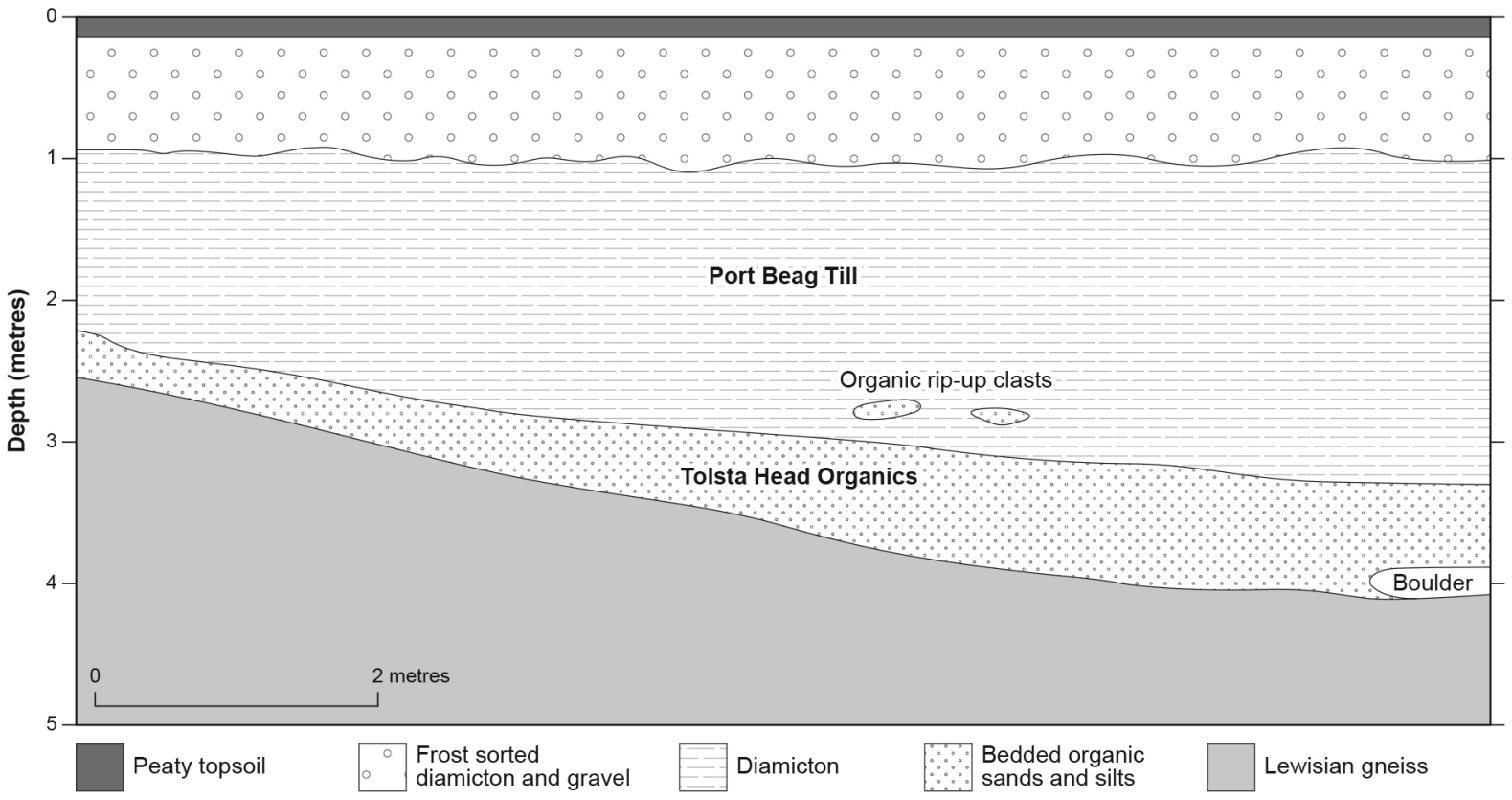




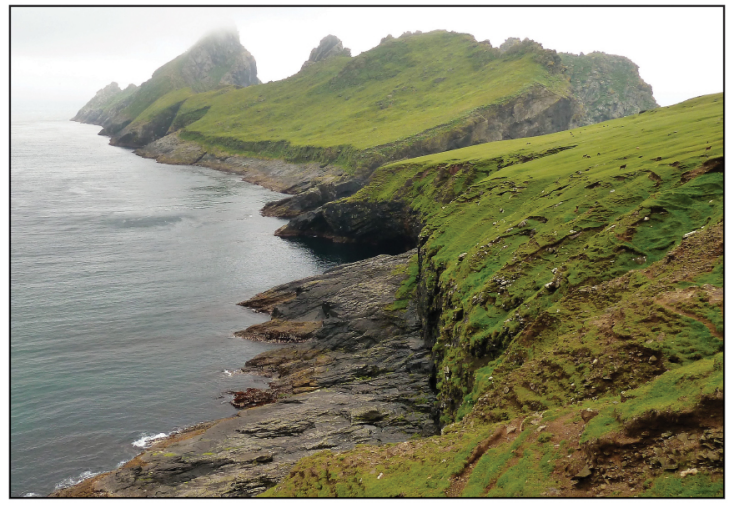




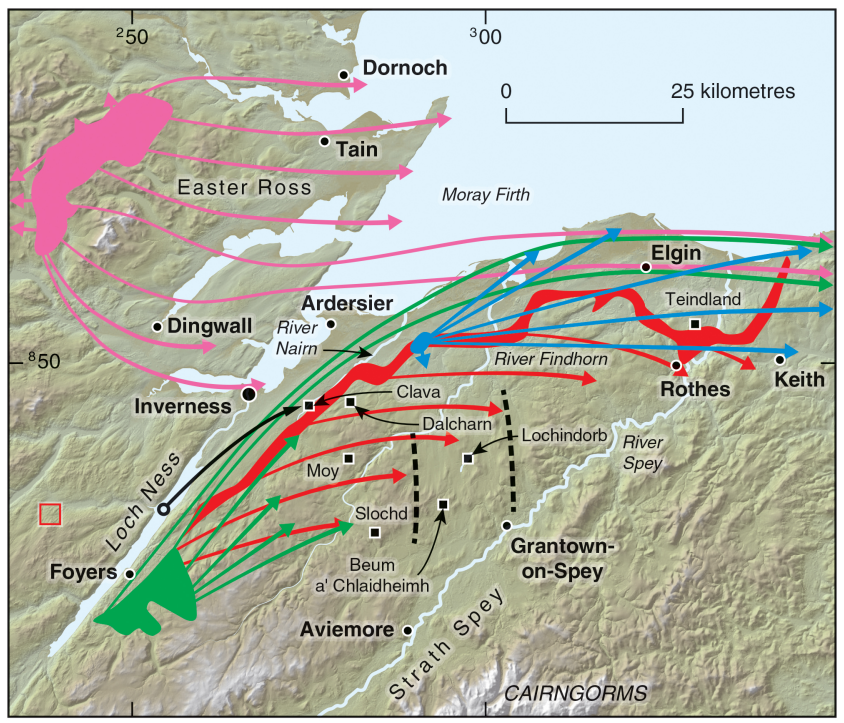

Southern limit of the Old Red Sandstone

Carn Chuinneag-Inchbae augen gneiss (extended to include ORS conglomerate in which clasts of this gneiss occur)
Foyers Granite
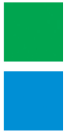

Auldearn

Granite

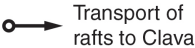

Approximate boundary of former corridor of fast-flowing ice

Megagrooves 


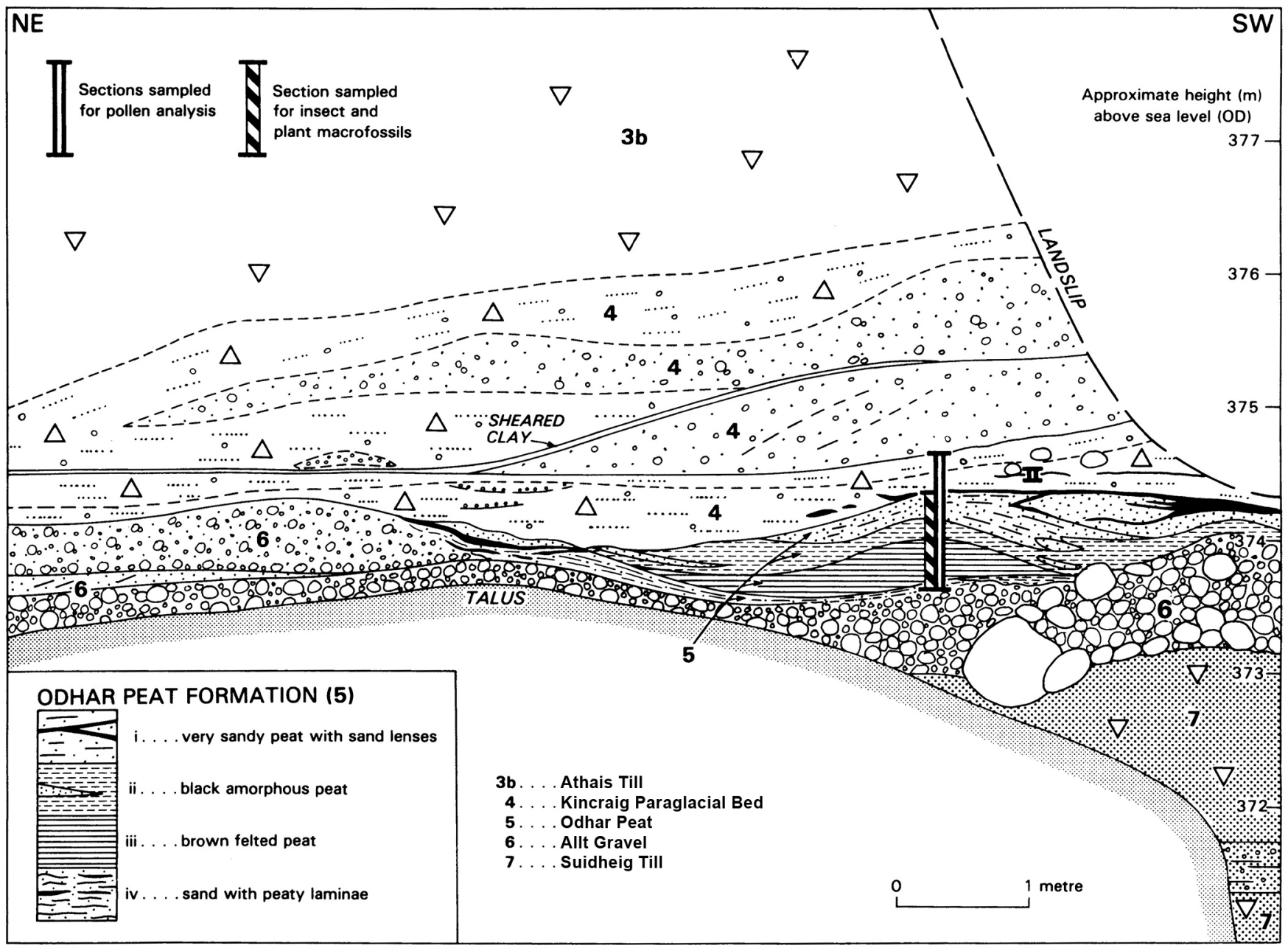




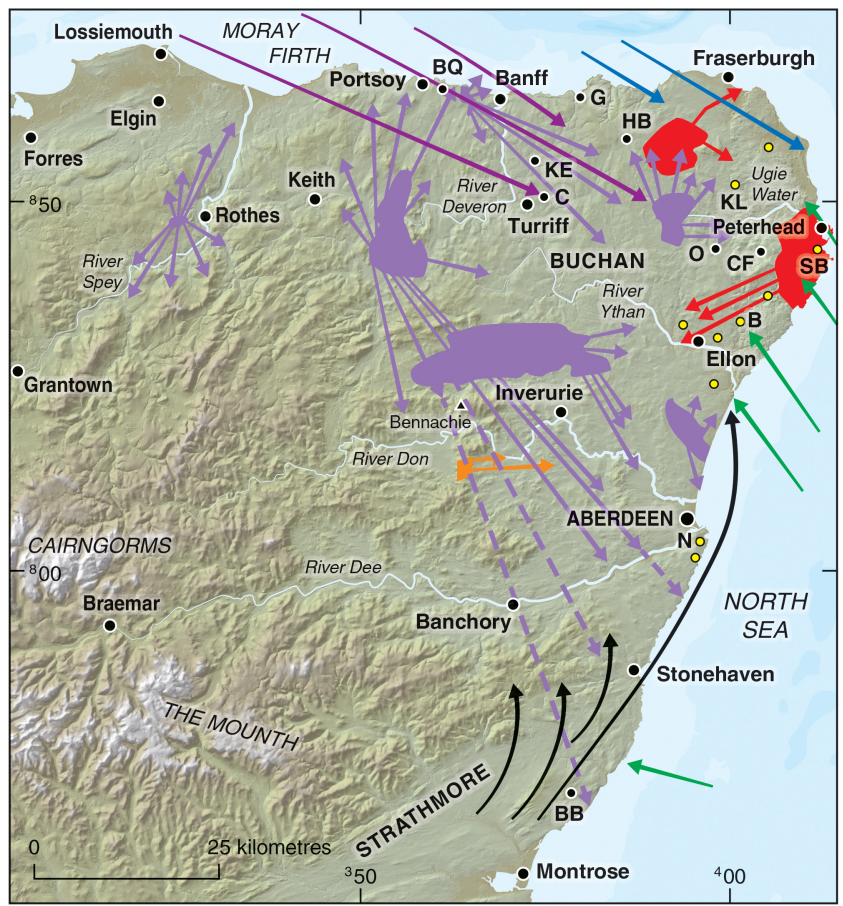

Basic and ultrabasic igneous rocks

Granites

Green Hill sillimanite gneiss

Note: Arrows show direction of transport of distinctive erratics

- Site with Scandinavian erratics found within Pleistocene deposits
B Bellscamphie

BB Burn of Benholm

BQ Boyne Quarry

C Crossbrae

CF Camp Fauld

G Gardenstown

HB Howe of Blyth

KE King Edward

KL Kirkhill/Leys

N Nigg Bay

O Oldmill

SB Sandford Bay 

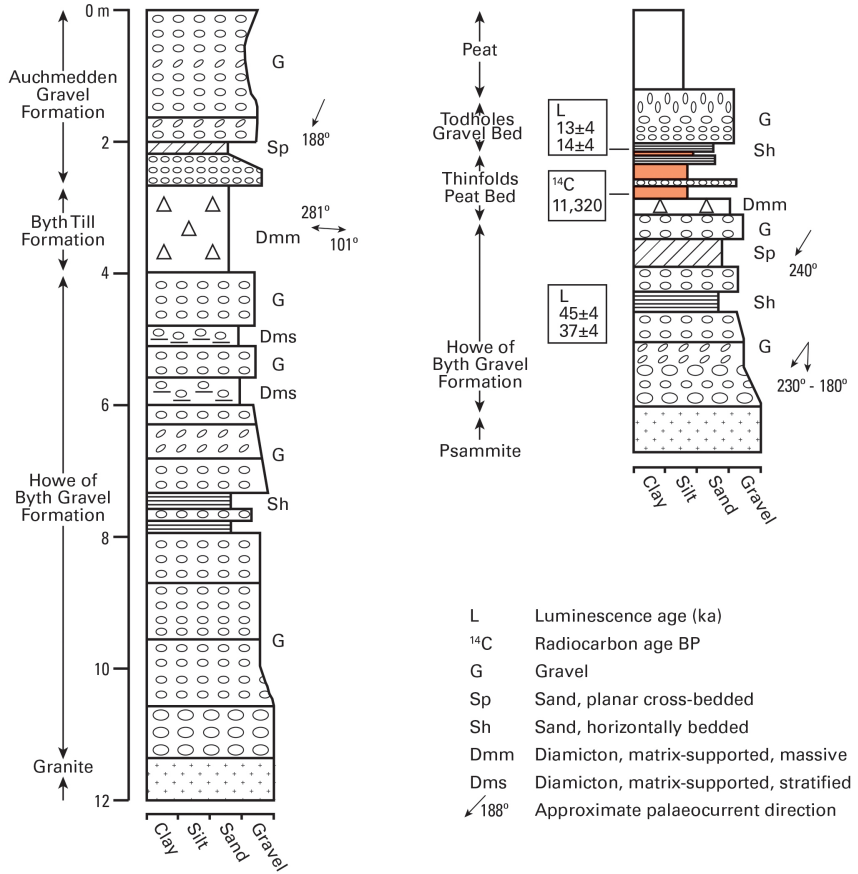

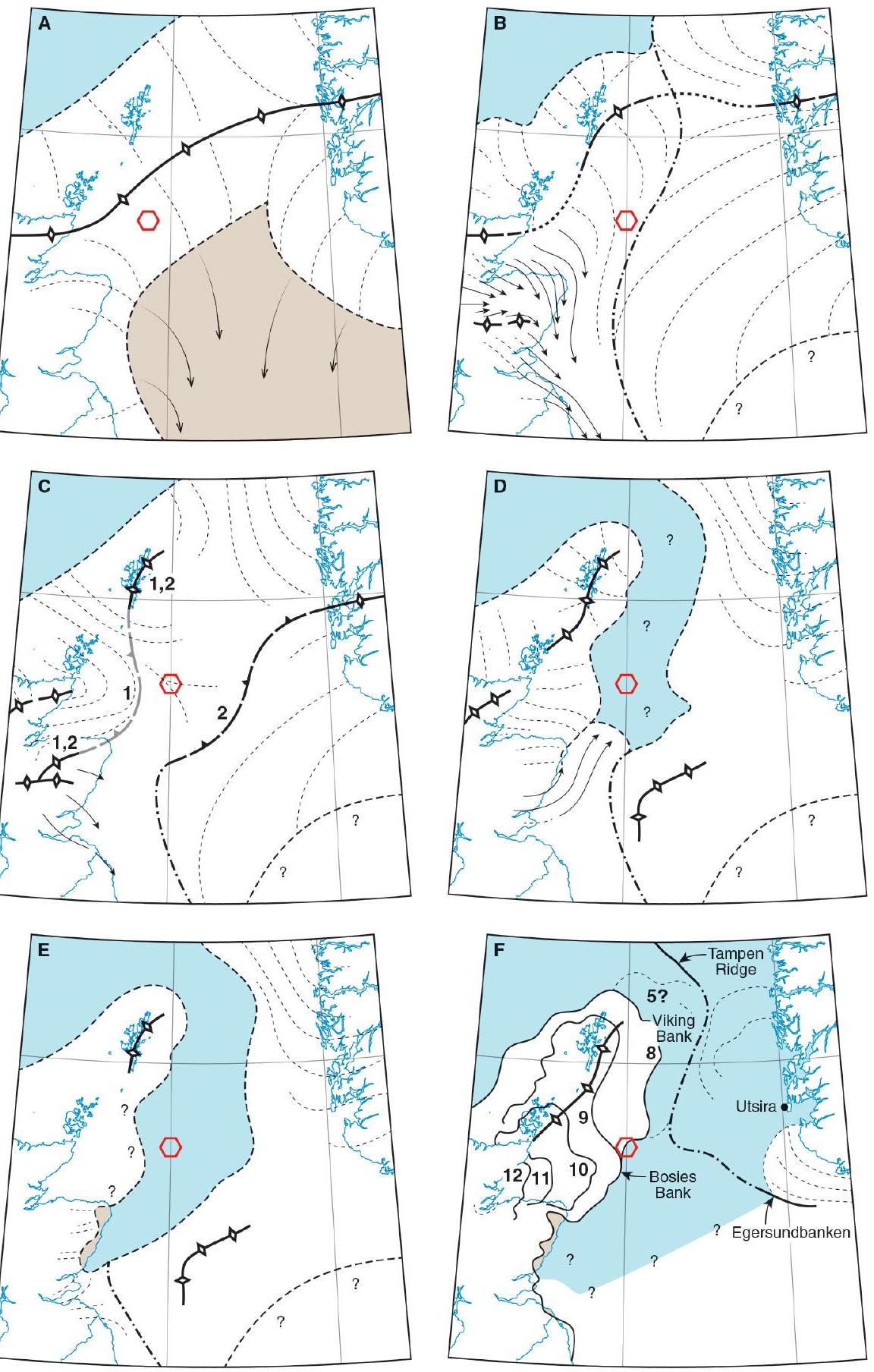


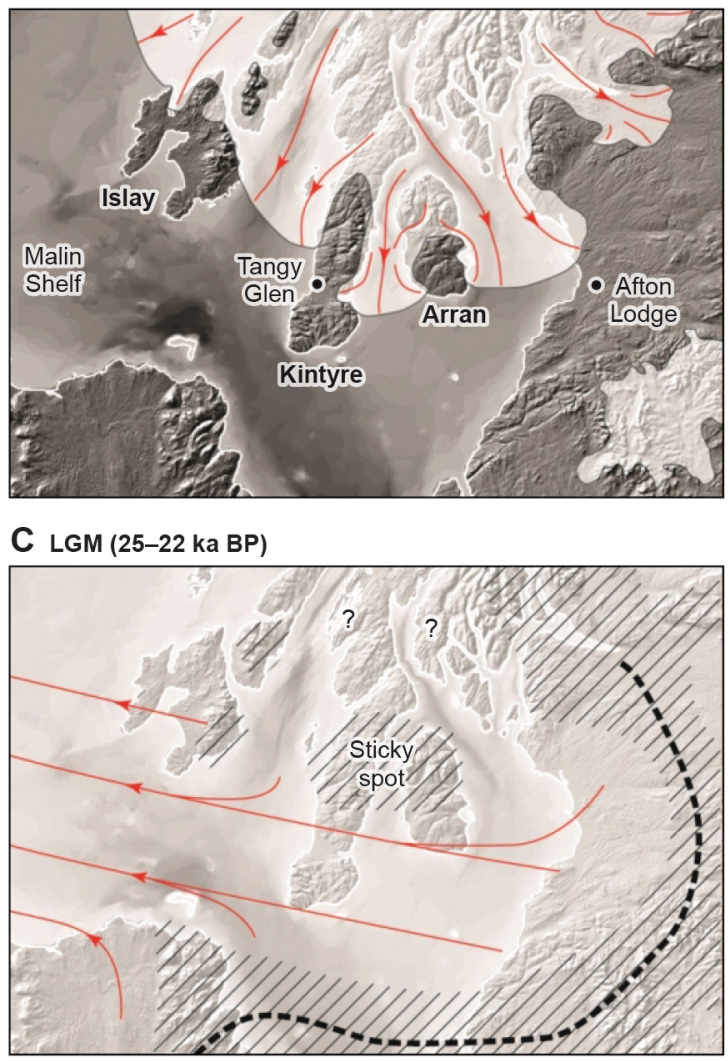

E 'Scottish Readvance' (19.2-18.2 ka BP)

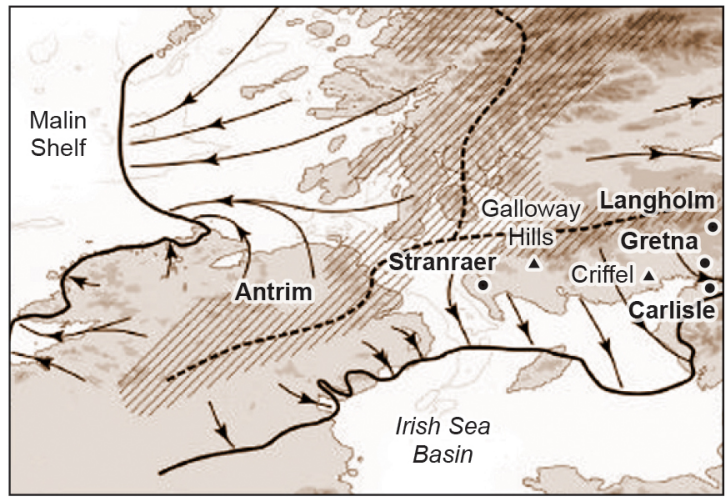

G (16.5-16.2 ka BP)

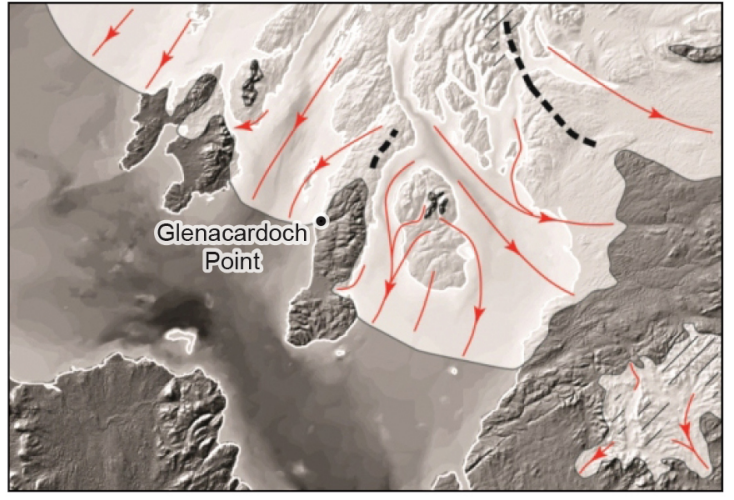

B LLGM (32-25 ka BP)

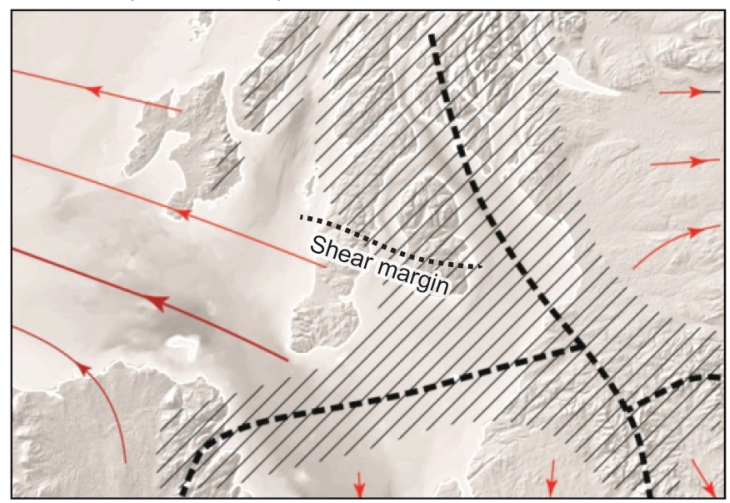

D (22-19 ka BP)

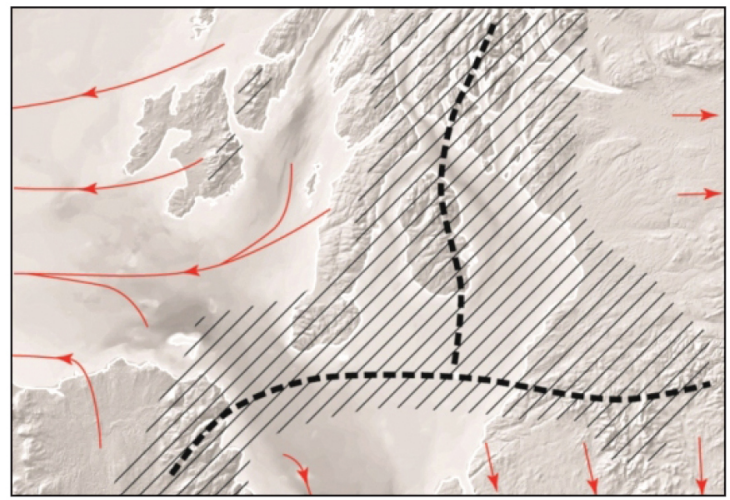

F ( 16.5 ka BP)

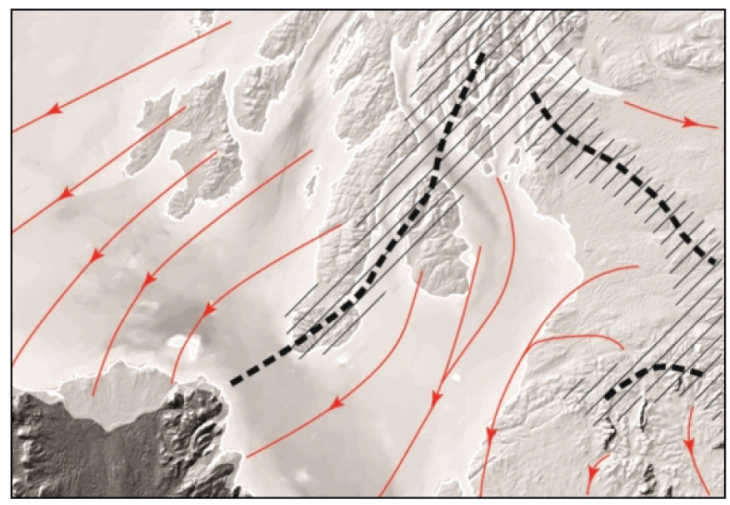

H ( 16.2 ka BP)

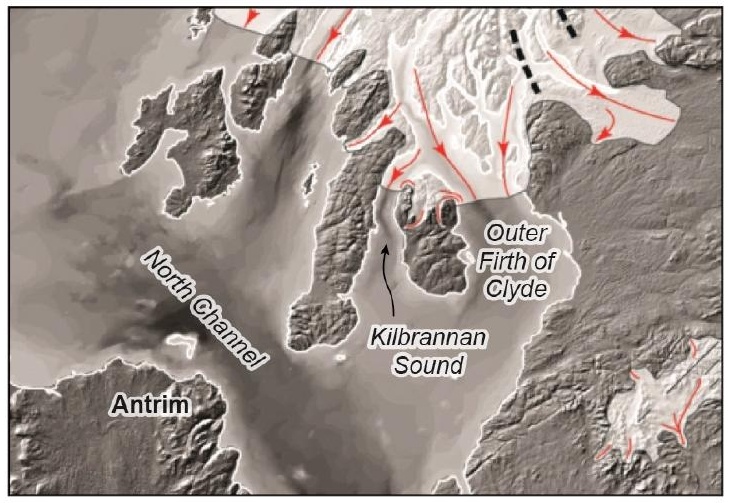




\begin{tabular}{|c|c|c|c|c|}
\hline \multicolumn{2}{|c|}{ Clyde/Glasgow } & $\begin{array}{l}\text { Marine } \\
\text { Isotope } \\
\text { Stage }\end{array}$ & Greenland & Ayrshire \\
\hline \multirow{3}{*}{\multicolumn{2}{|c|}{ 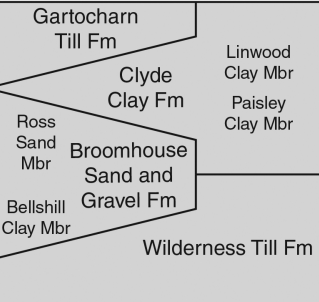 }} & $\begin{array}{l}2 \text { (LLS) } \\
2(\mathrm{LI})\end{array}$ & Gl-1e to Gl-1 & Clyde Clay Fm \\
\hline & & \multirow{2}{*}{2} & \multirow{2}{*}{ GS-5 to GS-2a } & Auchenwinsey Till Mbr \\
\hline & & & & Eglington Shelly Till Mbr \\
\hline \multirow{2}{*}{\multicolumn{2}{|c|}{$\begin{array}{l}\text { Cadder Sand Fm } \\
\text { (contains bones from } \\
\text { woolly rhinoceros) }\end{array}$}} & \multirow{2}{*}{3} & & Sourlie Organic Silt Fm \\
\hline & & & & $\begin{array}{l}\text { Armsheugh Sand } \\
\text { and Gravel Fm }\end{array}$ \\
\hline \multicolumn{2}{|l|}{ Ballieston Till Fm } & $\begin{array}{c}4 ? \\
\text { or } \\
\text { earlier }\end{array}$ & & $\begin{array}{c}\text { Lawthorne Diamicton Mbr } \\
\text { Littlestone Till Fm }\end{array}$ \\
\hline
\end{tabular}


A Ice sheet advance ( 35-32 ka BP)

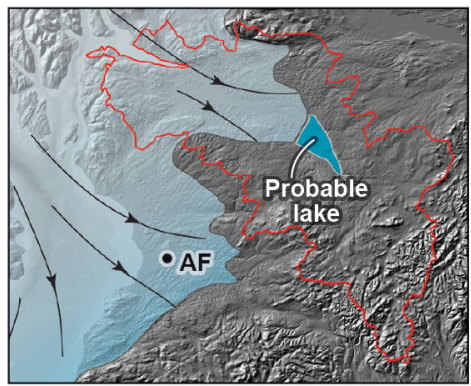

D Ice cap uncoupling ( 22-16.5 ka BP)

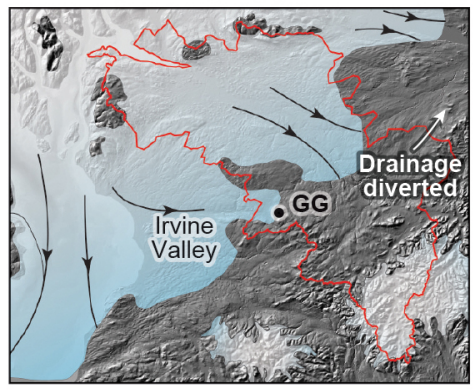

B LLGM ( 32-25 ka BP)

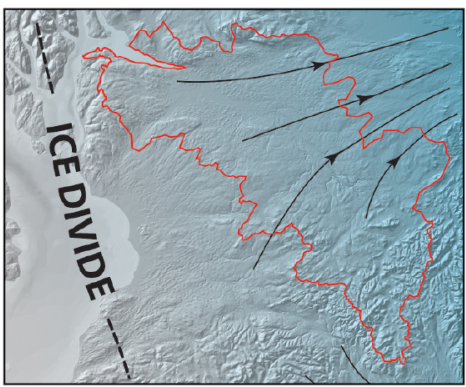

E Deglaciation (16.5-16.2 ka BP)

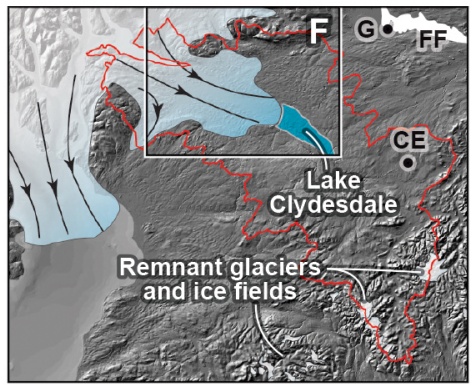

C LGM ( 25-22 ka BP)

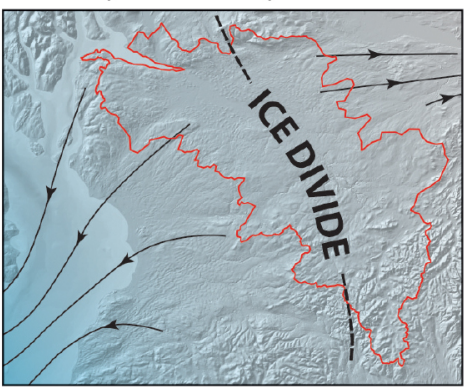

F

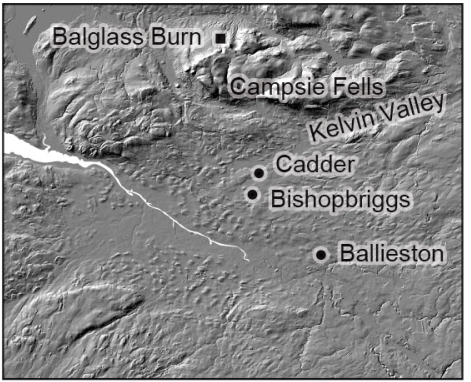




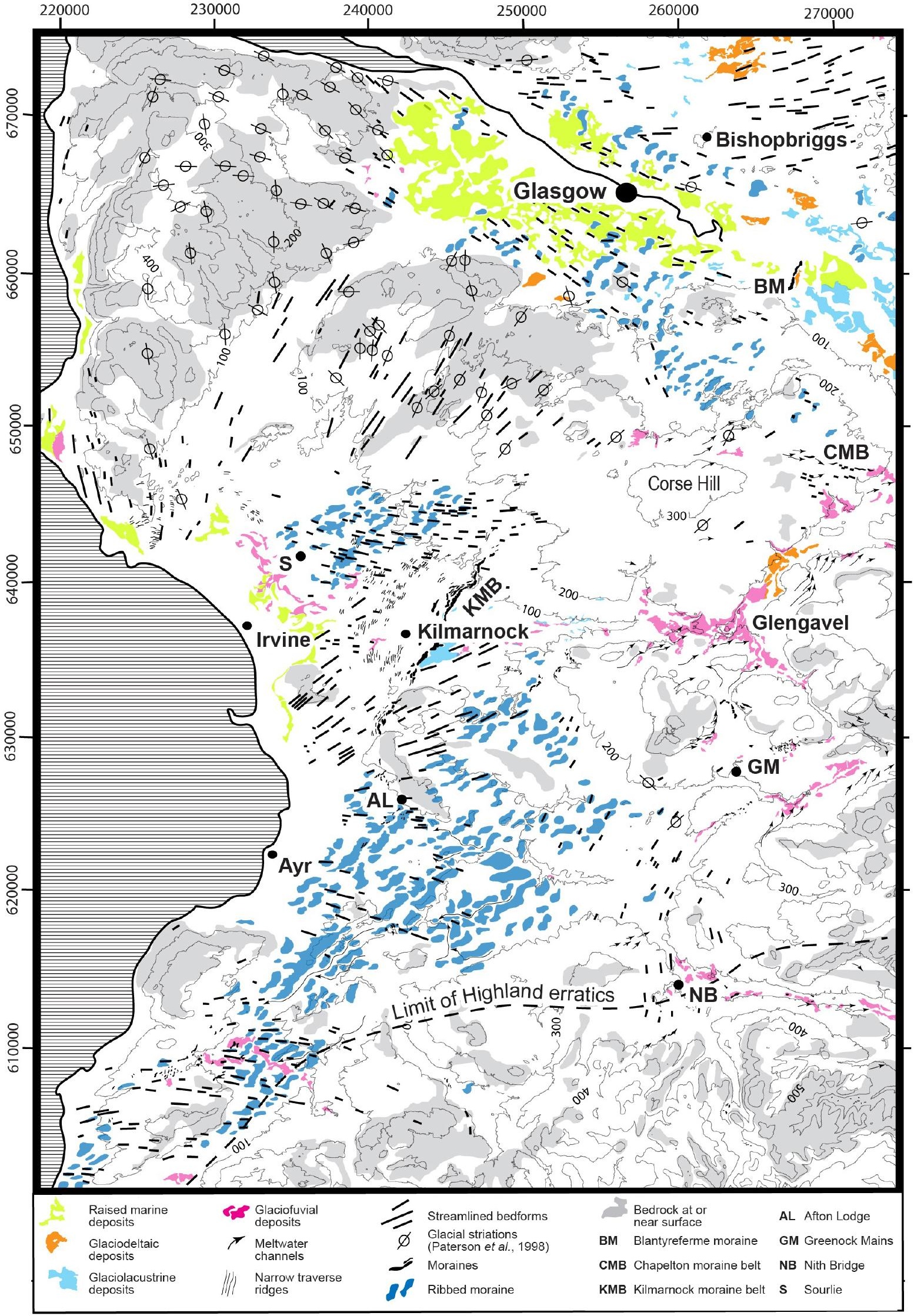




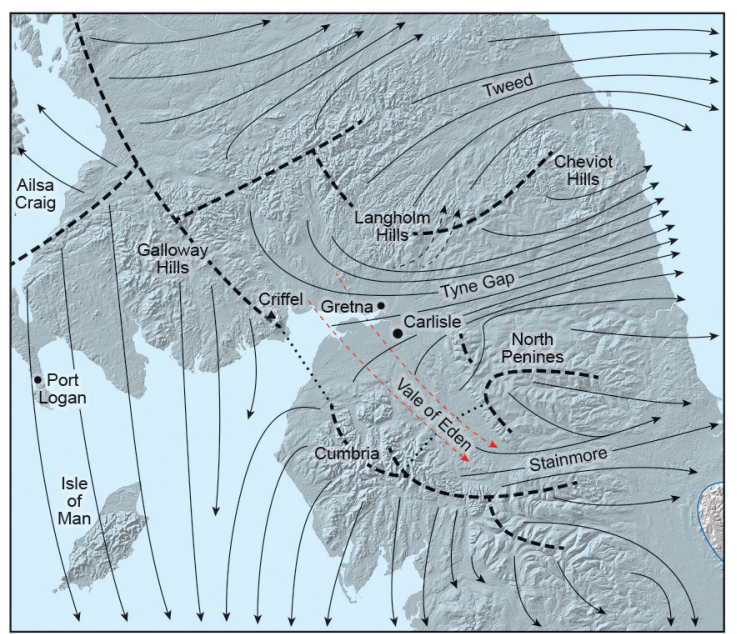

B

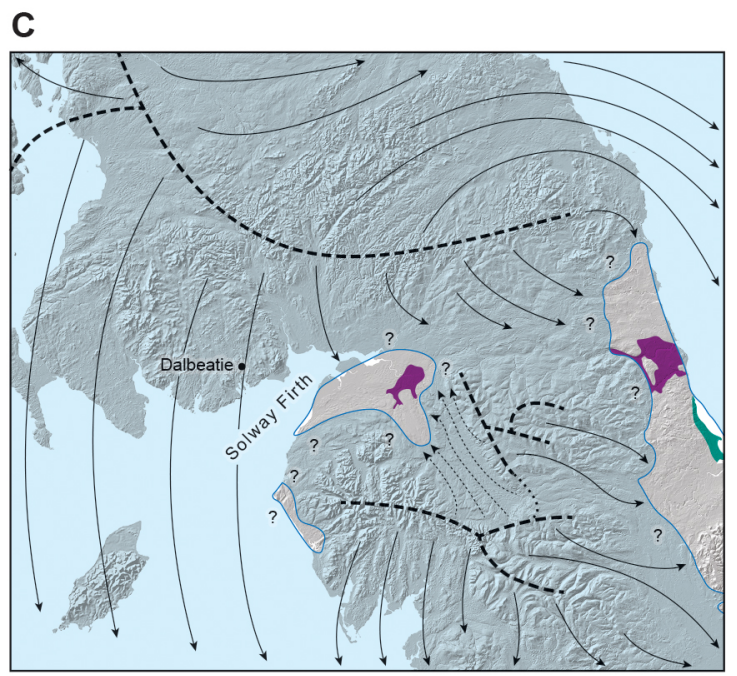

Sandur

Ice-dammed lakes

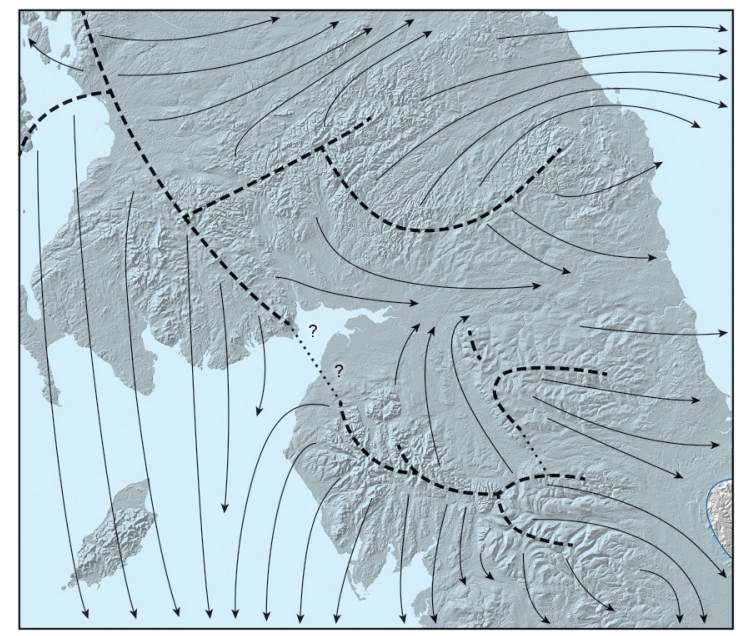

D

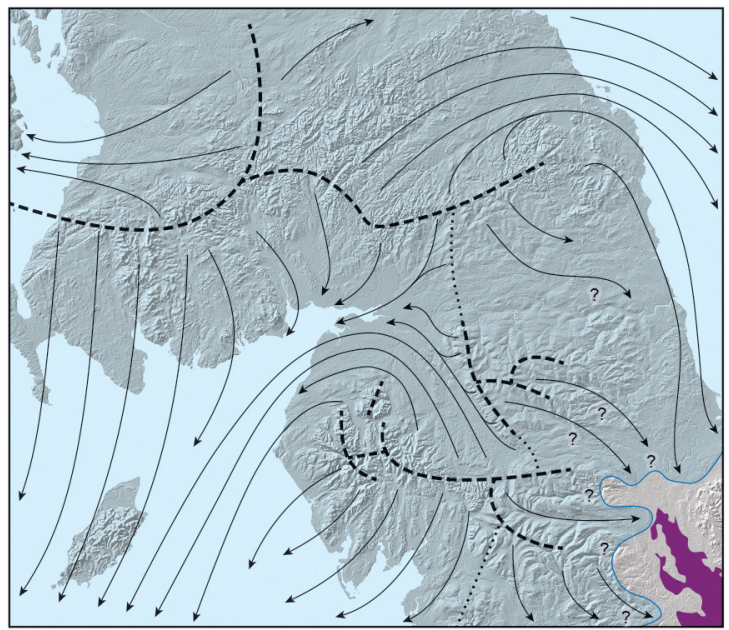

Ice-dammed lakes

F

E

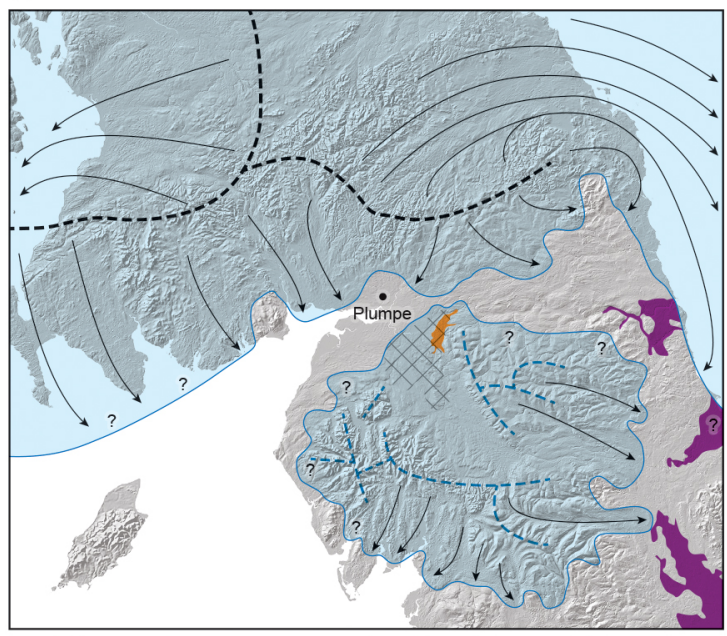

Kame belt

Ice-dammed lakes

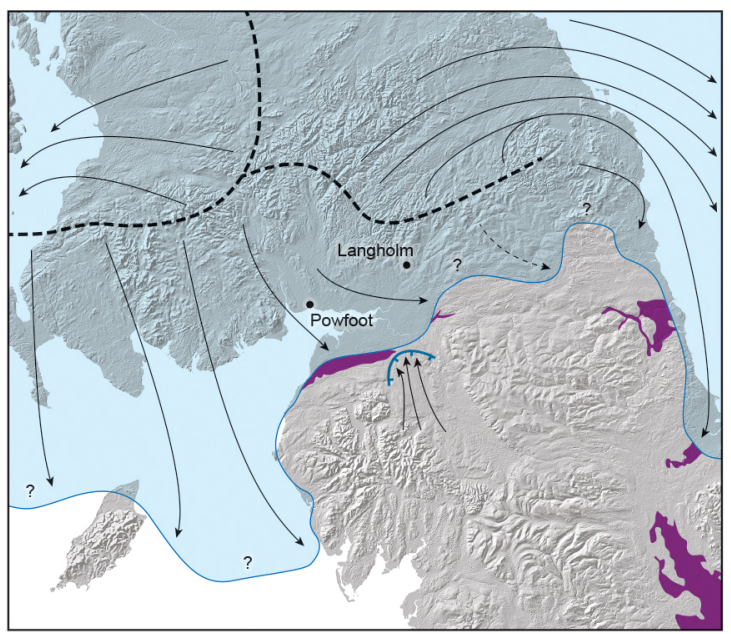

Ice-dammed lakes 